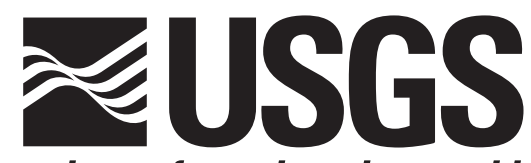

science for a changing world

\title{
Herpetofaunal Inventories of the National Parks of South Florida and the Caribbean: Volume I. Everglades National Park
}

By Kenneth G. Rice, U.S. Geological Survey, Florida

J. Hardin Waddle, and Marquette E. Crockett, Florida Cooperative Fish and Wildlife Research Unit

Brian M. Jeffery, University of Florida Department of Wildlife Ecology and Conservation

H. Frankin Percival, Florida Cooperative Fish and Wildlife Research Unit

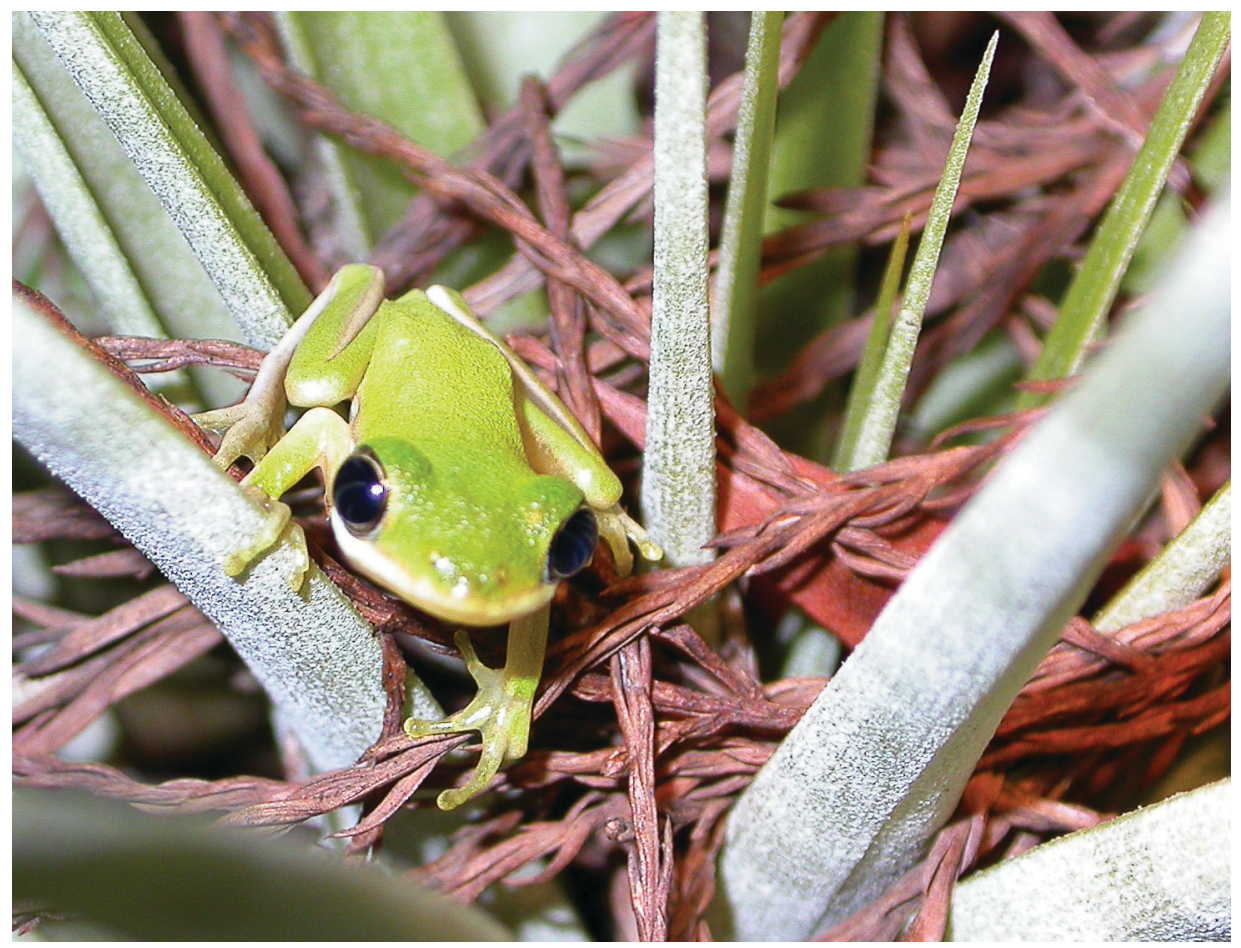

Open-File Report 2004-1065 


\title{
U.S. Department of the Interior Gale A. Norton, Secretary
}

\author{
U.S. Geological Survey \\ Charles G. Groat, Director
}

\section{U.S. Geological Survey, Reston, Virginia: 2004}

For sale by U.S. Geological Survey, Information Services

Box 25286, Denver Federal Center

Denver, CO 80225

\begin{abstract}
For more information about the USGS and its products:
Telephone: 1-888-ASK-USGS

World Wide Web: http://www.usgs.gov/

Any use of trade, product, or firm names in this publication is for descriptive purposes only and does not imply endorsement by the U.S. Government.

Although this report is in the public domain, permission must be secured from the individual copyright owners to reproduce any copyrighted materials contained within this report.
\end{abstract}

For more information about this report, contact:

Dr. Kenneth G. Rice, U.S. Geological Survey, Florida Integrated Science Center

UF-FLREC, 3205 College Av., Ft. Lauderdale, FL 33314, USA

E-mail: ken_g_rice@usgs.gov Phone: 954-577-6305 Fax: 954-577-6347

J. Hardin Waddle, Florida Cooperative Fish and Wildlife Research Unit

Box 110485, Building 810, University of Florida, Gainesville, FL 32611, USA

E-mail: hardin_waddle@usgs.gov Phone: 352-846-0638 Fax: 352-846-0841

Marquette E. Crockett, Florida Cooperative Fish and Wildlife Research Unit

Everglades N. P. Research Center, 40001 S.R. 9336, Homestead, FL 33034, USA

E-mail: marquette_crockett@partner.nps.gov Phone: 305-242-7809

Brian M. Jeffery, University of Florida, Dept. of Wildlife Ecology and Conservation

Big Cypress National Preserve, 33100 Tamiami Trail, Ochopee, FL 34141, USA

E-mail: brian_jeffery@usgs.gov Phone: 239-695-1148

Dr. H. Franklin Percival, Florida Cooperative Fish and Wildlife Research Unit

Box 110485, Building 810, University of Florida, Gainesville, FL 32611, USA

E-mail: percivalf@wec.ufl.edu Phone: 352-392-1861 Fax: 352-846-0841 


\section{Table of Contents}

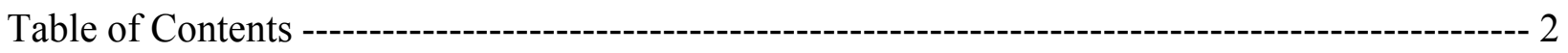

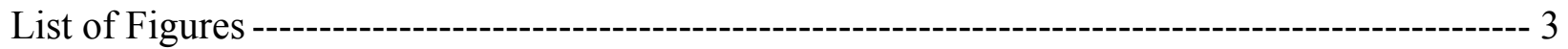

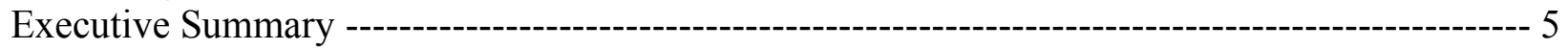

Methods ----------------------------------------------------------------------------------------------------------- 8

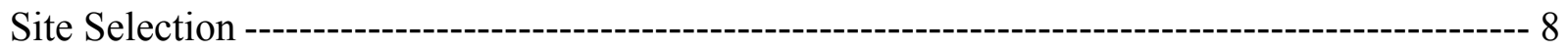

Visual Encounter Surveys -----------------------------------------------------------------------------10

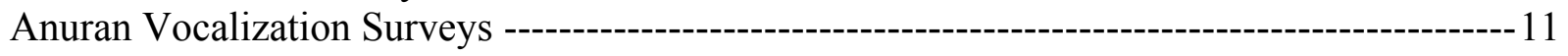

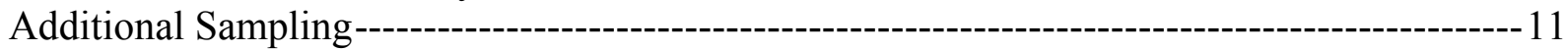

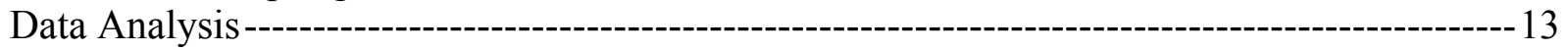

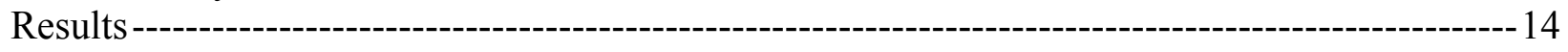

Anurans ----------------------------------------------------------------------------------------------------------- 14

Acris gryllus --------------------------------------------------------------------------------------------- 14

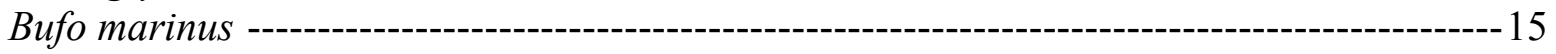

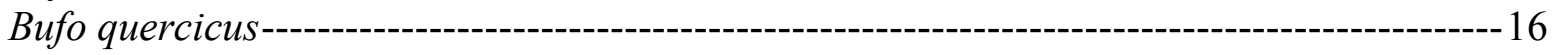

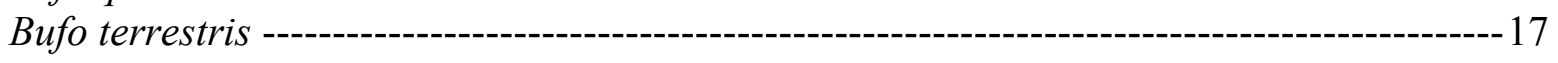

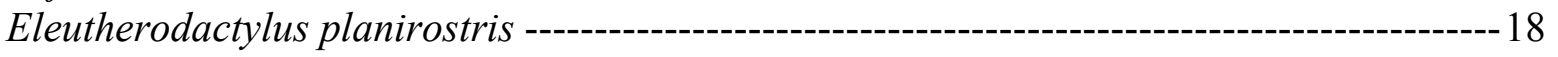

Gastrophryne carolinensis--------------------------------------------------------------------------- 19

Hyla cinerea --------------------------------------------------------------------------------------------20

Hyla squirella -----------------------------------------------------------------------------------------21

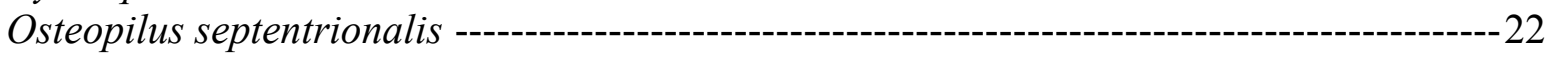

Pseudacris nigrita -------------------------------------------------------------------------------------24

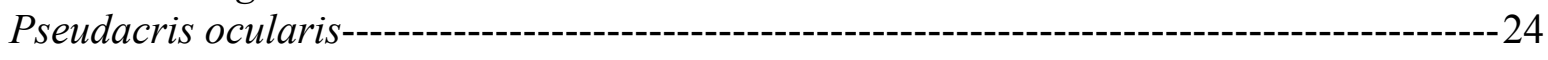

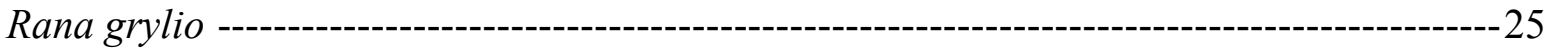

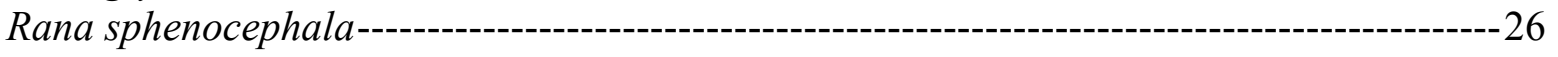

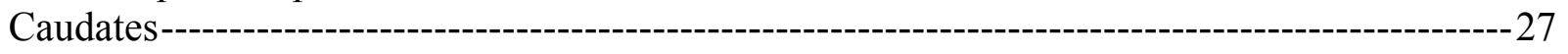

Amphiuma means --------------------------------------------------------------------------------------27

Notophthalmus viridescens --------------------------------------------------------------------------27

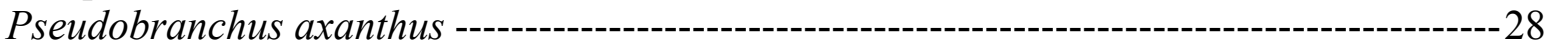

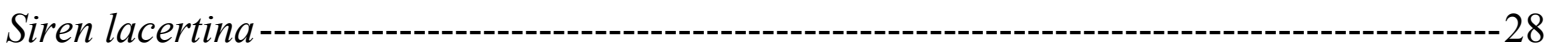

Reptiles ------------------------------------------------------------------------------------------------------29

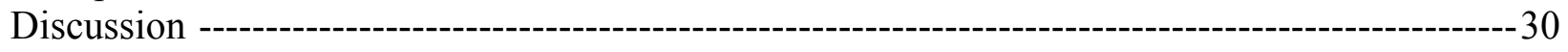

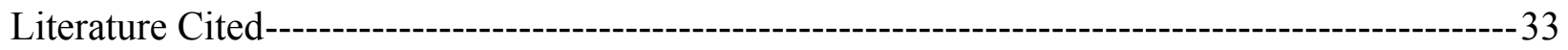

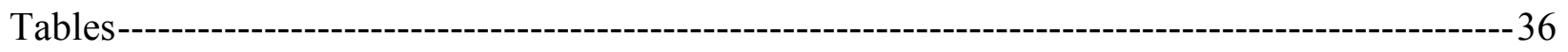

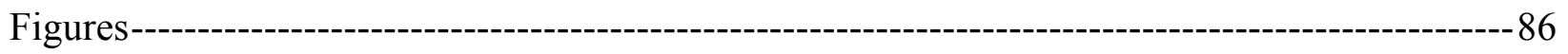




\section{List of Figures}

Figure 1: Vegetation classification of Everglades National Park ---------------------------------------86

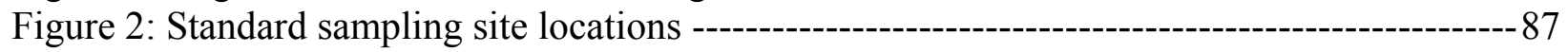

Figure 3: Sites sampled on a monthly basis ------------------------------------------------------------88

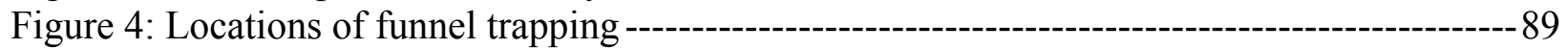

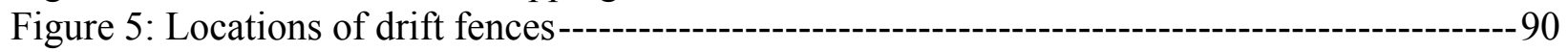

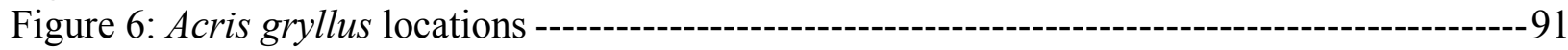

Figure 7: Bufo marinus locations ----------------------------------------------------------------------------92

Figure 8: Bufo quercicus locations ----------------------------------------------------------------93

Figure 9: Bufo terrestris locations ------------------------------------------------------------------------94

Figure 10: Eleutherodactylus planirostris locations------------------------------------------------------95

Figure 11: Gastrophryne carolinensis locations ----------------------------------------------------------96

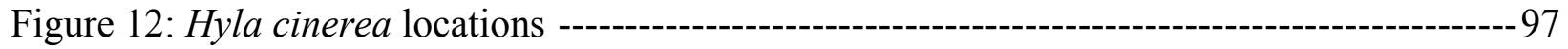

Figure 13: Hyla squirella locations ------------------------------------------------------------------------98

Figure 14: Osteopilus septentrionalis locations------------------------------------------------------------99

Figure 15: Pseudacris nigrita locations ----------------------------------------------------------------- 100

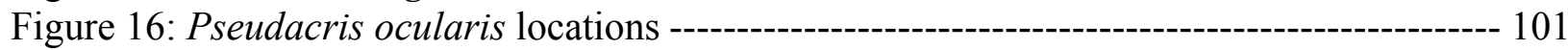

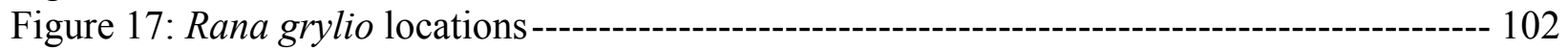

Figure 18: Rana sphenocephala locations ------------------------------------------------------------ 103

Figure 19: Amphiuma means locations---------------------------------------------------------------- 104

Figure 20: Notophthalmus viridescens locations------------------------------------------------------ 105

Figure 21: Siren lacertina locations -------------------------------------------------------------------- 106

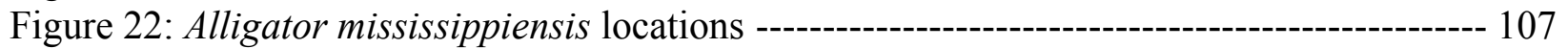

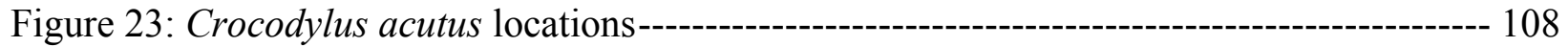

Figure 24: Anolis carolinensis locations --------------------------------------------------------------- 109

Figure 25: Anolis sagrei locations ------------------------------------------------------------------------ 110

Figure 26: Eumeces inexpectatus locations---------------------------------------------------------- 111

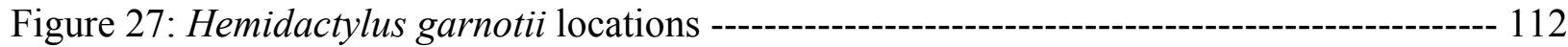

Figure 28: Hemidactylus mabouia locations ---------------------------------------------------------- 113

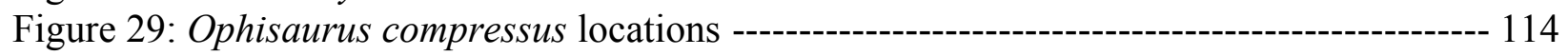

Figure 30: Scincella lateralis locations ----------------------------------------------------------------- 115

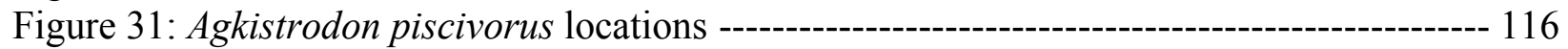

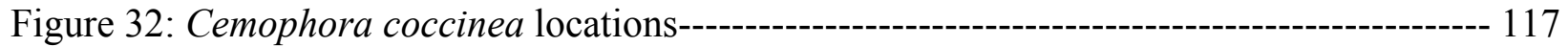

Figure 33: Coluber constrictor locations --------------------------------------------------------------- 118

Figure 34: Crotalus adamanteus locations ------------------------------------------------------------- 119

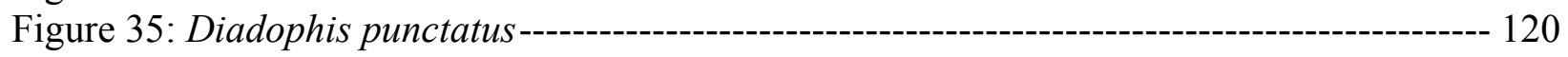

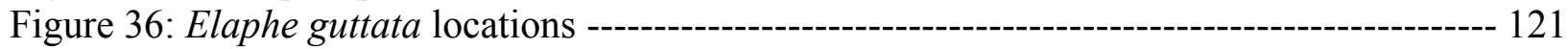

Figure 37: Elaphe obsoleta locations---------------------------------------------------------- 122

Figure 38: Farancia abacura locations ------------------------------------------------------------------ 123

Figure 39: Lampropeltis getula locations -------------------------------------------------------------- 124

Figure 40: Nerodia clarkii locations---------------------------------------------------------------------- 125

Figure 41: Nerodia fasciata locations -------------------------------------------------------------------- 126

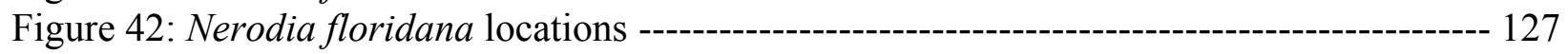




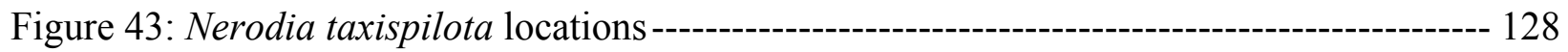

Figure 44: Opheodrys aestivus locations----------------------------------------------------------- 129

Figure 45: Python molorus locations ------------------------------------------------------------------- 130

Figure 46: Regina alleni locations ------------------------------------------------------------------------ 131

Figure 47: Sistrurus miliarius locations------------------------------------------------------------------ 132

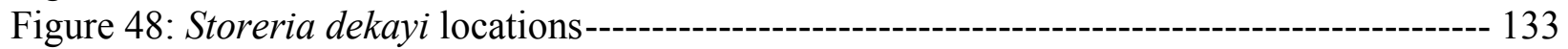

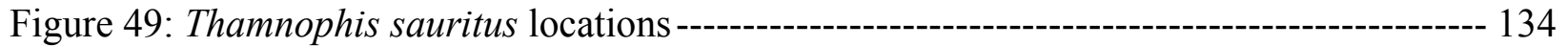

Figure 50: Thamnophis sirtalis locations ------------------------------------------------------------- 135

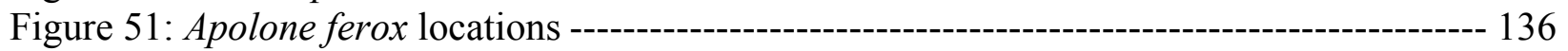

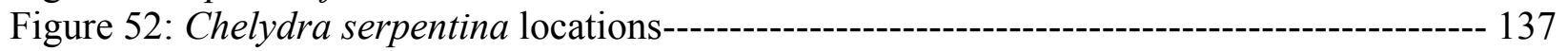

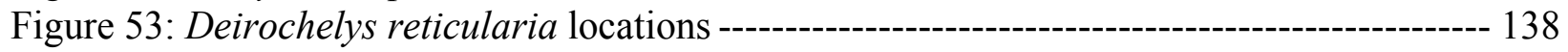

Figure 54: Gopherus polyphemus locations ----------------------------------------------------------- 139

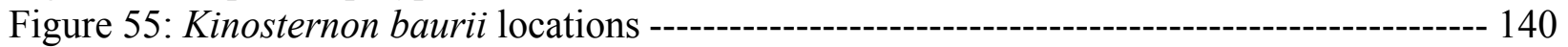

Figure 56: Kinosternon subrubrum locations --------------------------------------------------------- 141

Figure 57: Pseudemys floridana locations ------------------------------------------------------------- 142

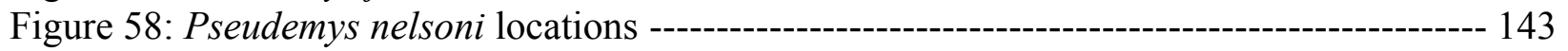

Figure 59: Terrapene carolina locations-------------------------------------------------------------- 144 


\section{Executive Summary}

Amphibian declines and extinctions have been documented around the world, often in protected natural areas. Concern for this alarming trend has prompted the U.S. Geological Survey and the National Park Service to document all species of amphibians that occur within U.S. National Parks and to search for any signs that amphibians may be declining. This study, an inventory of amphibian species in Everglades National Park, was conducted during 2000 to 2003. The goals of the project were to create a georeferenced inventory of amphibian species, use new analytical techniques to estimate proportion of sites occupied by each species, look for any signs of amphibian decline (missing species, disease, die-offs, etc.), and to establish a protocol that could be used for future monitoring efforts.

Several sampling methods were used to accomplish all of these goals. Visual encounter surveys and anuran vocalization surveys were conducted in all habitats throughout the park to estimate the proportion of sites or proportion of area occupied (PAO) by each amphibian species in each habitat. Opportunistic collections, as well as some drift fence and aquatic funnel trap data were used to augment the visual encounter methods for highly aquatic or cryptic species. A total of 562 visits to 118 sites were conducted for standard sampling alone, and 1788 individual amphibians and 413 reptiles were encountered. Data analysis was done in program PRESENCE to provide PAO estimates for each of the anuran species.

All but one of the amphibian species thought to occur in Everglades National Park was detected during this project. That species, the Everglades dwarf siren (Pseudobranchus axanthus belli), is especially cryptic and probably geographically limited in its range in Everglades

National Park. The other three species of salamanders and all of the anurans in the park were 
sampled adequately using standard herpetological sampling methods. PAO estimates were produced for each species of anuran by habitat. This information is valuable now as an indicator of habitat associations of the species and relative abundance of sites occupied, but it will also be useful as a comparative baseline for future monitoring efforts.

In addition to sampling for amphibians, all encounters with reptiles were documented. The sampling methods used for detecting amphibians are also appropriate for many reptile species. These reptile locations are included in this report, but there were not enough locations for most reptile species to analyze the PAO of individual species. 37 of the 57 species of reptiles thought to occur in Everglades National Park were detected during this study.

This study found no evidence of amphibian decline in Everglades National Park. There was one species not detected, but there is no evidence to indicate it has been extirpated from the park. Although no declines were observed, several threats to amphibians were identified. Introduced species, especially the Cuban treefrog (Osteopilus septentrionalis), are predators and competitors with several native frog species. Also, interference by humans with the natural hydrological cycle of the Everglades has the potential to alter the amphibian community. Finally, habitat loss outside the park has the potential to leave the amphibians in Everglades National Park isolated from other populations.

Continued monitoring of the amphibian species in Everglades National Park is recommended. The methods used in this study are adequate to produce reliable estimates of the proportion of sites occupied by most anuran species. Continuing this protocol is a cost-effective way of determining whether species are decreasing or increasing in abundance of sites occupied. 


\section{Introduction}

Declines in amphibian populations have been documented worldwide from many regions and ecosystems (Alford and Richards 1999). No single cause for declines has been demonstrated, and it seems likely that several factors may interact to threaten populations (Carey and Bryant 1995). A major factor in the loss of amphibian populations in the southeastern United States has been and continues to be the loss of habitat (Dodd and Cade 1998). In response to concerns about amphibian population declines, the Department of Interior received funding from Congress to institute long-term surveys of the status and trends of amphibians on DOI lands. This document describes an inventory of the amphibians of Everglades National Park that was conducted during 2000 to 2002.

Everglades National Park (EVER) protects 610,502 ha of natural areas at the extreme southern tip of Florida. EVER consists primarily of shallow seasonal wetland habitats including marshes, sloughs, cypress forests, and mangrove forests. In addition, a portion of the park consists of upland habitat; primarily pine forests and tropical hardwood hammocks. These habitats combined make up a heterogeneous matrix of open grasslands and forested wetlands and uplands.

This is not the first attempt to document the species of amphibians in EVER, but it is the most thorough survey to date. Duellman and Schwartz (1958) produced the first complete species list of the herpetofauna of south Florida. Meshaka et al. (2000) updated this to include

all species documented from within EVER as recently as 1999. Dalrymple (1988) studied the herpetofauna of the Long Pine Key area and documented 15 species of amphibians. He found that most were habitat generalists. 
This project is the first attempt to document the distribution of all amphibian species within EVER. In addition to providing a sample of georeferenced locations of all amphibian species in the park, we also estimated the site occupancy rate of each species by habitat. The occupancy rate is estimated based on detection/non-detection data from repeated sampling at randomly chosen sites throughout the park using a model developed by MacKenzie et al. (2002). This method can serve as an index of abundance, and it can be compared to future samples to determine trends in the status of amphibian populations.

\section{Methods}

We sampled for amphibians using several different methods at sites throughout Everglades National Park in an attempt to identify populations of all amphibian species in EVER. In addition to the standard sampling, opportunistic encounters with amphibians and reptiles were noted with details on the exact location of the capture and data on each individual animal.

\section{$\underline{\text { Site Selection }}$}

Sampling sites were chosen randomly throughout EVER using a geographic information system (GIS), and all of our sampling was stratified by major habitat type. We divided EVER into six natural habitats and two artificial habitats. The natural habitats we designated were: pineland, rocky glades, tropical hardwood hammock, mangrove forest, cypress dome, and freshwater slough (Figure 1). We created these habitat designations by condensing the vegetation classification scheme proposed by Madden et al. (1999) into our six broader habitat 
categories. The artificial habitats we sampled were categorized as canals and borrow pits or buildings and roads.

We used ArcView 3.2 with the Animal Movement Analysis extension (Hooge and Eichenlaub 1997) to select points at random within each major natural habitat type. We created more random points than could be sampled, so points were selected subjectively from the list of available points for sampling based on availability of access. Many parts of EVER were inaccessible by the means available to us (e.g. airboat, motorboat, 4-WD vehicle). Access was also seasonably variable. Areas accessible by airboat during the wet season were not always accessible during the dry season. We were, however, able to conduct some sampling in each habitat of EVER during each month of 2001.

In total we visited 118 sites at least twice (Figure 2). The artificial habitats had the fewest number of study sites (4 each), and slough had the most study sites (29) (Table 1). We visited between 14 and 18 sites in each of the other habitats. The number of sampling occasions per site was variable. Some were sampled on a monthly basis during 2001, and many were sampled no more than twice during the entire project. We used repeated sampling at a subset of the more accessible sites as an efficient way to estimate habitat level occupancy rates (Figure 3), while less frequent sampling at more remote locations provided better data on species distribution within the park. Our analysis includes a total of 562 site visits to the 118 sites (Table 1). Six sites in each habitat were sampled monthly during 2001 when access was possible. Some of the slough sites could not be sampled during the 2001 dry season (Feb. through May). 


\section{Visual Encounter Surveys}

Our primary method of sampling was a standard visual encounter survey (VES; Heyer et al. 1994) conducted for 30 minutes at the randomly chosen sites. All of our VES samples were begun at least 30 minutes after sunset because preliminary surveys in EVER showed that amphibians were more active and therefore more easily detected at night. Each VES was conducted by at least two experienced observers using powerful 6-volt lights with halogen bulbs.

Our VES samples were all within a 20-m radius circle of the randomly chosen point $\left(1256 \mathrm{~m}^{2}\right)$. We thoroughly searched as much of each circular plot as was possible in the time allotted, but judgment of the observers was used to determine which areas within the plot got the most emphasis. The goal was to find as many individual amphibians as possible. All possible amphibian locations could be searched including trees and other vegetation as well as bare ground and leaf litter.

We attempted to capture each individual amphibian and reptile that was observed during a VES. The animals were identified to species and sex if possible, and the age/life stage (i.e. juvenile, adult, larva, etc.) was recorded. The snout-to-vent length (SVL) of each animal captured was measured in mm, and the substrate on which each individual was first observed and the perch height (estimated to the nearest $10 \mathrm{~cm}$ ) was noted.

In addition to the biological data collected during a VES, we also collected some key environmental data in the field at the time of the survey. We measured the air temperature and relative humidity using a digital thermohygrometer. We recorded whether the plot was inundated with water, and if it was, the water temperature was measured and recorded. We also noted the weather and classified it into one of five categories: clear, partly cloudy, cloudy, rain, 
or fog. Wind speed was classified as none, light, moderate, or strong. The date and time of the sample and the observers present was also recorded. All data were recorded on personal digital assistants (PDAs) and later transferred to a Microsoft Access database (Waddle et al. 2003).

\section{$\underline{\text { Anuran Vocalization Surveys }}$}

At each random point when a VES was conducted, we also noted all of the species of frogs and toads that were heard vocalizing. The vocalization survey was a 10-minute period during the VES. All anurans that could be heard were included, even if it was possible or likely that they were calling from a location outside of the $20 \mathrm{~m}$ radius plot. Including all individuals heard eliminated the need to locate vocalizing individuals, and it facilitates comparison with similar surveys conducted elsewhere or in future studies in EVER.

The abundance of vocalizing individuals was estimated as one of five categories: one individual, 2-5 individuals, 6-10 individuals, $>10$ individuals, or large chorus. In addition, the frequency of calling by each species was categorized as occasional, frequent, or continuous. These categories were discussed with newer observers in the field so that a consensus could be reached on which category to place the abundance and frequency of calls.

\section{Additional Sampling}

We also used several other techniques in addition to the random sampling described above to attempt to fully document the amphibian fauna of EVER. Most of this sampling was done to either augment the species list or as part of other research projects. Data from this additional sampling is only included in the list of species detected and their locations. Because 
sites were not randomly chosen and sampling effort was not consistent, these data are not compatible with the proportion of sites occupied analysis technique used for the VES and vocalization surveys (see Data Analysis below).

The additional sampling primarily consisted of trapping. Funnel traps were used without drift fences at several sites within the Shark Valley Slough (Figure 4). These traps were primarily used to target aquatic salamanders, a group that was rarely observed during VES surveys. Traps were placed at 27 different sites during the summer of 2002, and each was open for four trap-nights. Amphibian and reptile bycatch data from 13 drift fences, maintained as part of a study of the freshwater fish in the rocky glades portion of the park (W. Loftus, USGS, 4005 SR 9336, Homestead, FL, 33034, unpub. data), was another important source of data (Figure 5). This sampling added several reptiles that were not often encountered using the VES technique. Another capture method, PVC pipe refugia (Boughton et al. 2000), was used to sample treefrogs more intensively at five sites throughout the park. While this is method is primarily effective for treefrogs, several other amphibian and reptile species were also captured as bycatch. These records are included as opportunistic encounters in this project, and the results of the capture-mark-recapture experiment with the treefrogs will be presented in a separate report.

The gopher tortoise burrows at Middle Cape Sable were also examined using a burrow camera in an attempt to document the use of burrows by commensal amphibians and reptiles. No commensals were discovered during this investigation, but an accurate estimate of the gopher tortoise population was produced (Waddle et al. 2004). 


\section{$\underline{\text { Data Analysis }}$}

Detection probabilities for all amphibian and reptile species were assumed a priori to be less than one. Therefore, data were collected in a method compatible with the site occupancy model of MacKenzie et al. (2002). This method estimates sampling occasion specific detection probabilities for each species using maximum likelihood statistical techniques. By estimating detection probabilities, we were able to estimate the true site occupancy rate of each species by habitat, while taking into account the effects of environmental variables on the behavior of the animals. We do not need to assume that detection rates are constant across species, habitats, time, or environment. We do assume, however, that if a species is present, it has a detection probability greater than 0 . We also assume that sites are closed to changes in occupancy between subsequent samples, and we therefore only consider data from surveys that were conducted within six months of one another.

All data were compiled in Microsoft Access and then extracted as capture histories for analysis in program PRESENCE (MacKenzie et al. 2003). Our site-specific covariables, those that directly affect the estimate of occupancy ( $p s i)$ were major habitat type and a broader habitat category (Forested or Grassland). Variables that affect detection probability $(p)$ were sampling occasion covariables: air temperature, relative humidity, presence of standing water, and season of the year. For each species, we considered twenty-seven models that were combinations of these variables that we determined to be biologically meaningful a priori (Table 2 ). The best model was chosen as the one with the lowest value for Akaike's information criterion (AIC), or the model with the best fit for the fewest parameters (Burnham and Anderson 1998). Model 
selection in this manner allows us to determine the factors that are the most important in sampling for individual species, and enables us to choose the best estimate of the site occupancy of each species. We used the best model that included the six habitats as a factor to estimate the habitat-specific occupancy rates of each species using the logit of the coefficient for each habitat from the model (MacKenzie et al. 2002).

\section{Results}

During this project we encountered 1788 amphibians and 413 reptiles during VES sampling. We also captured an additional 177 amphibians and 142 reptiles in drift fences, funnel traps, and by opportunistic encounter. We found 15 of the 16 species of amphibians listed in Meshaka et al. (2000) during this study. The species not detected at all during the sampling was the Everglades dwarf siren, Pseudobranchus axanthus (see below). We also collected one species of amphibian that was not previously reported from EVER, the giant toad, Bufo marinus. We encountered 37 of the 57 species of reptiles reported in Meshaka et al. (2000). This study did not target reptiles, but as some of the species are readily sampled using the same methods as those for amphibians we report the results below.

\section{$\underline{\text { Anurans }}$}

Acris gryllus

The Florida cricket frog (Acris gryllus dorsalis) is widespread throughout EVER. These frogs were detected in every habitat within the park using vocal survey (Table 4; Figure 6), and the species was heard on 140 of 562 sampling occasions. Locations where Acris gryllus were 
detected are shown in Figure 6. Cricket frogs were detected continuously by vocal survey between May and December 2001. While breeding may occur year round in this species, our results suggest that vocal survey would be most effective during these months.

During VES, a total of 84 cricket frogs were captured within the park. They were found in every habitat except mangrove. However, these occurrences were concentrated between May and September (Table 17). Because of the small size of this species and the abbreviated period during which detection by visual methods was possible, vocalization may be the most effective method for surveying this species. Snout-vent lengths (SVL) were taken from 37cricket frogs within the park. SVL measurements for this species ranged from 10-23mm with a mean of 15.02 $\mathrm{mm}(+/-3.61 \mathrm{SD})$ (Table 3). No significant differences were found in the snout vent lengths of cricket frogs in different habitats (Table 30).

The naïve or minimum site occupancy for the species was 0.58 overall, with values ranging from 0.00 to 0.90 among different habitats (Table 38). It was estimated that cricket frogs occupied $72.76 \%($ S.E. $=0.0444)$ of all sites within EVER. The best model for site occupancy estimation included all six habitats and temperature, humidity, and the presence/absence of water as covariates. No other models had any weight. Using the best model, the estimate of site occupancy for each habitat was computed, and results ranged from 0 to $100 \%$ among the habitats (Table 38).

\section{Bufo marinus}

The Marine or Cane toad (Bufo marinus) was introduced into south Florida in the 1960's as both a control for agricultural pests and as a pet. The species was not found in EVER during 
previous surveys of the park (Meshaka et al. 2000). However, vocalizations were heard at several sites during this inventory (Figure 7). Marine toads were heard calling in every natural habitat within the park (Table 5) on 13 of 562 visits. The timing of detection was sporadic, with vocalizations heard in February, August, November, and December (Table 18). This suggests that this species may be active year round in south Florida.

No marine toads were found within the park during VES. This fact, combined with the relatively low numbers of Bufo marinus detected by our vocal survey may indicate that this species has only recently begun to invade the park. However, marine toads were not found near disturbed habitats using either survey method. Therefore, inferences about the mode of invasion of these toads cannot be made from this data.

\section{Bufo quercicus}

The oak toad (Bufo quercicus), a small diurnal bufonid, was rarely found during our survey in EVER. This species was only heard during 4 of 562 samples, in pineland and disturbed habitat, and one individual was found during VES in rocky glades habitat (Table 6; Figure 8). These occurrences were concentrated within the summer rainy months (Table 19). The low number of oak toads detected by this survey is probably not reflective of their true distribution and abundance. Bufo quercicus, unlike other toads in the park, is chiefly active during the day. Therefore, the design of this study (sampling at night) was less appropriate for this particular species. Anecdotal evidence (opportunistic encounters by researchers during daylight hours) does suggest that the species is prevalent in pineland and rocky glades habitats within the park. Snout-vent length was taken from the individual oak toad collected during this study (Table 3). 
The naïve or minimum site occupancy for the species was 0.25 overall, with values ranging from 0.00 to 0.50 among different habitats (Table 39). We estimate that B. quercicus occupied $25.34 \%$ (S.E. $=0.0161)$ of all sites within EVER. The best model for site occupancy estimation included all six habitats and all four seasons as covariates. A model including three habitats and four seasons as covariates produced a very similar AIC value that may be equally suitable. No other models had any weight. Taking the best model we computed the estimate of site occupancy for each habitat, results ranged from 0 to $100 \%$ among the habitats (Table 39).

\section{Bufo terrestris}

Another toad within EVER, the southern toad (Bufo terrestris), was detectable using our methods. Southern toads were heard calling in 5 of 9 habitats within the park on 15 of 562 sampling occasions (Table 7). Vocalizations were heard chiefly in late winter-early spring and again in early fall. This corresponds with the known breeding pattern for this species, which may occur from March to October depending on rainfall and weather conditions (Conant and Collins 1991).

Southern toads were found visually in every habitat in EVER except cypress and borrow pit/canal habitat (Figure 9). However, only 10 specimens were found during VES, and these occurrences were scattered throughout the year (Table 20). This may indicate that while breeding is dependent upon rainfall and weather in this species, the toads are active and subject to survey at any time during the year. Therefore, it seems that both visual and vocal surveys are appropriate for this species. Mean SVL of Bufo terrestris within EVER was $58.33 \mathrm{~mm}(+/-$ 22.75 SD) with a range of 40 to $100 \mathrm{~mm}$ (Table 3). Due to the low number of individuals 
captured during this study, we were unable to determine if significant differences existed between mean SVL of southern toads in different habitats (Table 31).

The naïve or minimum site occupancy for the species was 0.20 overall, with values ranging from 0.00 to 0.29 among different habitats (Table 40). We estimate that $B$. terrestris occupied $42.26 \%($ S.E. $=0.0729)$ of all sites within EVER. The best model for site occupancy estimation was all six habitats as covariates. A model including all of the same sampling occasion covariates but with humidity produced a very similar AIC value that may be equally suitable. No other models had any weight. Taking the best model we computed the estimate of site occupancy for each habitat, results ranged from 0 to $100 \%$ among the habitats (Table 40$)$.

\section{Eleutherodactylus planirostris}

Possibly the most widespread of the three established exotic anurans in south Florida, the Greenhouse frog (Eleutherodactylus planirostris planirostris) was also found in EVER (Figure 10). Greenhouse frogs were heard vocalizing on 25 of 562 visits to the park (Table 8). Vocalizations were concentrated between May and September. This period corresponds to the summer rainy season, the known breeding period for this species. Using VES, 10 greenhouse frogs were found in the park, in hardwood, pineland, and rocky glades habitats. These frogs were found throughout the year (Table 21), which suggests that they are active year round in south Florida. Based on the data collected during this study, it seems that either visual or vocal surveys are viable methods for monitoring greenhouse frogs. However, vocal surveys would be most effective during the rainy season. Snout vent lengths of greenhouse frogs ranged from 20- 
$24 \mathrm{~mm}$ with a mean of $21.33 \mathrm{~mm}(+/-2.31 \mathrm{SD})$ (Table 3). We were unable to determine if significant differences existed in mean size of greenhouse frogs by habitat (Table 32).

The naïve or minimum site occupancy for the species was 0.15 overall, with values ranging from 0.00 to 0.53 among different habitats (Table 41). We estimate that E. p. planirostris occupied $36.47 \%$ (S.E. $=0.0565)$ of all sites within EVER. The best model for site occupancy estimation included all six habitats and four seasons as covariates. No other models had any weight. Taking the best model we computed the estimate of site occupancy for each habitat, results ranged from 0 to $100 \%$ among the habitats (Table 41 ).

\section{Gastrophryne carolinensis}

Eastern narrowmouth toads (Gastrophryne carolinensis) were heard on 22 of 562 vocal surveys within EVER. Vocalizations were concentrated between April and September, again corresponding with the rainy season in south Florida. Narrowmouth toads are explosive breeders, with short breeding periods concurrent with warm seasonal rains. These frogs were heard in every habitat within the park (Table 9; Figure 11), including disturbed areas. Visual surveys located 7 individual narrowmouth toads, in a variety of habitats (Table 22). Occurrences of narrowmouth toads are shown in Figure 12. Gastrophryne carolinensis were found by VES primarily in spring and fall, suggesting that this may be the time period during which visual survey is most effective. Only one narrowmouth toad was captured during this study. This individual had a SVL of $22 \mathrm{~mm}$, which is within normal range of the species (Table 3). No inferences could be made about differences in SVL by habitat for this species. 
The naïve or minimum site occupancy for the species was 0.18 overall, with values ranging from 0.07 to 0.75 among different habitats (Table 42). We estimate that G. carolinensis occupied $57.41 \%($ S.E. $=0.2219)$ of all sites within EVER. The best model for site occupancy estimation included all three habitats and four seasons as covariates. Models that included three habitats with humidity as a covariate and three habitats with humidity, temperature, and water as covariates produced similar AIC values that may be equally suited. No other models had any weight. Taking the best model we computed the estimate of site occupancy for each habitat, results ranged from 28 to $67 \%$ among the habitats (Table 42 ).

\section{Hyla cinerea}

The green treefrog (Hyla cinerea) was the most commonly observed amphibian species during our sampling in EVER. This species was detected in every habitat in the park using either VES or vocalization methods (Table 10; Figure 12). Hyla cinerea appears to be a habitat generalist in the Everglades ecosystem. We captured a total of 1149 individual $H$. cinerea during VES surveys, and we heard at least one $H$. cinerea vocalizing during 151 of our 562 samples. H. cinerea was detected by either VES or vocalization at least once at a total of 98 of our 118 sites.

We detected H. cinerea during every month of the year 2001 (Table 23). H. cinerea was captured during VES surveys in every month, and detected through vocalizations from March through September. This suggests that $H$. cinerea remains active throughout the year and may always be detectable using VES techniques. The period during which they were found vocalizing corresponds with the wetter portion of the annual rain cycle in south Florida. 
Therefore detection probabilities based on $H$. cinerea vocalization may only be greater than 0 during the wet season and this method is appropriate for only that portion of the year. Morphometric data were collected from $838 \mathrm{H}$. cinerea captured during VES. The overall mean SVL of green treefrogs in EVER was on the lower end of the known size range for the species with a mean SVL of $27.7 \mathrm{~mm}(+/-6.1 \mathrm{SD})$ and a range from 12 to $57 \mathrm{~mm}$ (Table 3). The mean SVL, when categorized by habitat, showed the same trend toward smaller individuals and no real differences existed between sizes in different habitats (Table 33).

The naïve or minimum site occupancy for the species was 0.83 overall, with values ranging from 0.44 to 1.00 among different habitats (Table 43). The high detection probability of H. cinerea led to PAO estimates only slightly higher than the naïve estimates. We estimate that H. cinerea occupied $88.23 \%$ (S.E. $=0.0343)$ of all sites within EVER. The best model for site occupancy estimation included all six habitats and temperature, humidity, and the presence/absence of water as covariates. A model including all of the same sampling occasion covariates but with habitat divided into forest vs. grassland produced a very similar AIC value that may be equally suitable. No other models had any weight. Taking the best model we computed the estimate of site occupancy for each habitat, results ranged from 49 to $100 \%$ among the habitats (Table 43).

\section{Hyla squirella}

The squirrel treefrog (Hyla squirella) was another common hylid in EVER. H. squirella was detected by VES in every habitat and by vocalization in five of nine surveyed habitats (Table 11; Figure 13). The presence of Hyla squirella in all habitats suggests that this species 
may also be a habitat generalist, although not as ubiquitous as Hyla cinerea. A total of $108 \mathrm{H}$. squirella were found using VES, and the species was heard during 19 of 562 samples.

H. squirella was detected by VES during 9 of our 12-month surveys, with continuous detection between July and December. Detection of $H$. squirella by vocalization occurred in April, May, July, and September (Table 24). While this is consistent with the breeding period of H. squirella in Florida (Conant and Collins 1991), the absence of this species from several months of vocal survey suggests that VES may be a more effective survey method for $H$. squirella. Measurements were taken from 65 individual H. squirella captured by VES. The mean SVL for squirrel treefrogs in EVER was $20.88 \mathrm{~mm}$ (+/-4.09 SD), which is slightly lower than the published size range for this species (Table 3). Mean SVL for squirrel treefrogs, categorized by habitat, are shown in Table 34.

The naïve or minimum site occupancy for H. squirella was 0.31 overall, with values ranging from 0.10 to 0.65 among different habitats (Table 44). It was estimated that $H$. squirella occupied $57.73 \%($ S.E. $=0.0866)$ of all sites within EVER. The best model for site occupancy estimation included all six habitats and four seasons as covariates. Models including the six habitats and water produced a similar AIC value that may be equally suited. No other models had any weight. Taking the best model, the estimate of site occupancy for each habitat was computed, and results ranged from 24 to $97 \%$ among the habitats (Table 44$)$.

\section{Osteopilus septentrionalis}

The Cuban treefrog (Osteopilus septentrionalis) is an exotic hylid species present in EVER since the 1950's (Meshaka et al. 2000). O. septentrionalis was detected by VES in 
habitats dominated by woody vegetation and in disturbed habitats (i.e. buildings and roads) (Table 12). This distribution is consistent with known habitat preferences for this species (Meshaka 2001). Vocal survey also detected O. septentrionalis in disturbed and wooded habitats. In addition, the species was also heard once within slough habitat (Table 12). Locations of O. septentrionalis found within the park are shown in Figure 14. Ninety-eight individual $O$. septentrionalis were captured during VES and at least one vocalization was heard during 10 of the 562 sampling occasions. The overall mean SVL of Cuban treefrogs captured during this study was $43.83 \mathrm{~mm}(+/-15.32 \mathrm{SD})$ (Table 3). While no statistical differences were found in the mean SVL of Cuban treefrogs when separated by habitat, it seems that individuals found in cypress tended to be generally be smaller than individuals found in other habitats (Table 35).

O. septentrionalis was detected by VES every month of our sampling year. This indicates that $O$. septentrionalis is active throughout the year and may always be detectable using visual techniques. O. septentrionalis was detected by vocal survey during April, May, August, September, and October. It is possible that $O$. septentrionalis vocalizes sporadically between April and October and simply was not encountered during our June and July surveys (Table 25).

The naïve or minimum site occupancy for the species was 0.17 overall, with values ranging from 0.00 to 0.50 among different habitats (Table 45). It was estimated that $O$. septentrionalis occupied $34.66 \%$ (S.E. $=0.0664)$ of all sites within EVER. The best model for site occupancy estimation included forested and grassland habitats and four seasons as covariates. A model including all six habitats and four seasons produced a very similar AIC value that may be equally suitable. No other models had any weight. Taking the best model, the 
estimate of site occupancy for each habitat was computed. These results ranged from 0 to $100 \%$ among the habitats (Table 45).

\section{Pseudacris nigrita}

The southern chorus frog (Pseudacris nigrita) was a relatively rare hylid species within the park. P. nigrita was found only in pineland habitat during VES survey. Vocal survey further detected southern chorus frogs in rocky glades and hardwood habitats (Figure 15). Only 7 individuals of this species were captured, and vocalizations were only heard during 8 of our 562 sampling occasions (Table 13). The snout-vent length of the one individual captured during this study was $25 \mathrm{~mm}$ (Table 3). There was insufficient data to examine differences in SVL by habitat.

P. nigrita was detected in only two months of our sampling year using either visual or vocal surveys (Table 26). This suggests that there may be a very limited time period during which the probability of detection of $P$. nigrita by any sampling method is greater than 0 . There was insufficient data to obtain detection probabilities for this species.

\section{Pseudacris ocularis}

The little grass frog (Pseudacris ocularis) was rarely encountered within EVER. Five individual $P$. ocularis were found within three habitats during VES (Table 14). Vocalizations for P. ocularis were not heard during our sampling year (Figure 16). No snout-vent lengths were obtained for this species (Table 3). 
P. ocularis was encountered using VES in three months of survey (Table 27). However, the distribution of these occurrences does not correspond with any particular season. This suggests that there may not be an optimal time to sample for $P$. ocularis. Instead, it seems that this species either occurs in low abundances in EVER or is significantly more difficult to detect than other hylid species using visual and vocal survey techniques. No detection probabilities were obtained for of $P$. ocularis due to insufficient data.

\section{Rana grylio}

The pig frog (Rana grylio) was also widespread throughout the park. This species was detected in every habitat using vocalization techniques, and was found in 6 habitats using VES (Table 15; Figure 17). A total of 121 individual R. grylio were captured during VES, and the species was heard vocalizing during 153 of 562 samples. The overall SVL of pig frogs within EVER was $61.77 \mathrm{~mm}(+/-27.67 \mathrm{SD}$; Table 3). As with several other species in the park, this length is below the published range for this species. No significant differences were found when SVL's were categorized by habitat (Table 36).

During the study, R. grylio were captured 11 months out of the 12 month period using VES. The species was detected by vocalization 8 months out of the year (Table 28). This suggests that this species may remain active throughout the year and may always be detectable using VES.

The naïve or minimum site occupancy for the species was 0.61 overall, with values ranging from 0.44 to 1.00 among different habitats (Table 46). We estimate that $R$. grylio occupied $73.01 \%$ (S.E. $=0.0418)$ of all sites within EVER. The best model for site occupancy 
estimation included all six habitats and temperature, humidity, and the presence/absence of water as covariates. No other models had any weight. Taking the best model we computed the estimate of site occupancy for each habitat, results ranged from 27 to $100 \%$ among the habitats (Table 46).

\section{Rana sphenocephala}

The most common ranid species found during this survey was the southern leopard frog (Rana sphenocephala). This species was encountered using VES techniques in every habitat and was detected by vocal survey in 5 habitats (Table 16; Figure 18). The mean SVL of captured individuals ranged from 25 to $89 \mathrm{~mm}$ with a mean of $50.14 \mathrm{~mm}(+/-16.87 \mathrm{SD})$ (Table 3). No significant differences were found in the SVL of southern leopard frogs found in different habitats within the park (Table 37).

R. sphenocephala was encountered every month of our sampling year by VES (Table 29). It was found during eight months of the sampling year using vocalizations. These months did not correspond directly to any season or to the breeding period for this species. This suggests that while either survey method is somewhat effective, visual methods seem to be most reliable. One hundred sixty-five individual $R$. sphenocephala were found during VES surveys, and vocalization by at least one individual was heard during 37 of our 562 samples.

The naïve or minimum site occupancy for the species was 0.41 overall, with values ranging from 0.18 to 0.67 among different habitats (Table 47). Estimates indicated that $R$. sphenocephala occupied 71.48\% (S.E. $=0.0915)$ of all sites within EVER. The best model for site occupancy estimation included all three habitats and temperature and the presence/absence 
of water as covariates. A model including all of the same sampling occasion covariates but with the presence/absence of water produced a very similar AIC value that may be equally suitable. No other models had any weight. Taking the best model, the estimate of site occupancy for each habitat was computed, with results ranging from 38 to $100 \%$ among the habitats (Table 47 ).

\section{$\underline{\text { Caudates }}$}

\section{Amphiuma means}

The two-toed amphiuma (Amphiuma means) was the most numerous salamander found during this study. A total of 37 individuals were captured using various survey techniques. While most individuals were found as bycatch from drift fence arrays used for fish surveys in rocky glades habitats, funnel trapping within Shark Slough was also an effective method for catching this species (Table 48). Locations of these captures are shown in Figure 19. No measurements were taken from individuals caught using drift fences or VES. However, SVL's were taken from the two individuals caught during funnel trapping. The measurements were 350 and $360 \mathrm{~mm}$ in length, suggesting that the two individuals were adult specimens. No PAO analysis was performed for this species.

\section{Notophthalmus viridescens}

The peninsula newt (Notophthalmus viridescens piaropicola), the only member of the family salamandridae found in south Florida, was also present within EVER. A total of 12 individuals were found in the park, with the majority being caught during VES (Table 48; Figure 20). No measurements were taken from individuals encountered in drift fence arrays or during 
VES. However, two individuals collected during funnel trapping were measured. The snout-vent lengths of these individuals were 44 and $35 \mathrm{~mm}$. No PAO analysis was performed for this species.

\section{Pseudobranchus axanthus}

The Everglades dwarf siren (Pseudobranchus axanthus belli), a subspecies endemic to south Florida, was not found during this survey. The species had been previously listed from the park (Meshaka et al. 2000), and is believed to currently be present. However, since the species was not detected by our survey methods, it is possible that either it exits in low numbers in the park or has a life history incompatible with our survey techniques.

\section{Siren lacertina}

Another member of the family sirenidae, the greater siren (Siren lacertina), was detected within the park using our methods. A total of 30 greater sirens were found during this study (Table 48). The majority of these individuals were found as bycatch from drift fence arrays for fish in rocky glades habitats within the park. However several individuals were also found by funnel trapping and VES (Table 48). Occurrences of this species throughout the park are shown in Figure 21. Measurements were not taken from individuals found during VES or while using drift fence arrays. The four individuals found using funnel traps were measured from snout to vent and weighed. The length of greater sirens caught by funnel trapping ranged from 274 to 620 $\mathrm{mm}$ with an average of $381 \mathrm{~mm}(+/-160.97 \mathrm{SD})$. 


\section{$\underline{\text { Reptiles }}$}

While the primary focus of this study was to sample amphibian species within EVER, many of the methods used were also appropriate for sampling reptiles. Therefore, we have collected and summarized the data on reptile species encountered during this study. Meshaka et al. (2000) listed 57 species of reptiles present in EVER. During this study, we encountered 37 of those species. The reptile species found during this study are listed in Table 49, along with the methods by which they were found. Locations of occurrences by species are shown alphabetically within classes (crocodilians figures 22-23; lizards figures 24-30; snakes figures 31-50, and turtles figures 51-59)

Three reptile species found during this study are exotic to south Florida. The brown anole, Anolis sagrei, was the most abundant exotic reptile found in the park, with 229 individuals being found during VES alone. Brown anoles were primarily found near disturbed areas within the park (Figure 25). Another exotic, the tropical house gecko, Hemidactlyus mabouia was also found near disturbed areas. Thirteen individual house geckos were found during VES, with the majority of these being on buildings. The third exotic reptile encountered during this study was Python molorus, the Burmese python. One individual snake was found as road-kill on the main park road, and was collected.

In addition to exotics, we also encountered three species of concern during this study. The gopher tortoise, Gopherus polyphemus, is listed by the state of Florida as a "species of special concern". The gopher tortoise burrows at Middle Cape Sable were examined using a burrow camera in an attempt to document the use of burrows by commensal amphibians and reptiles. No commensals were discovered during this investigation, but an accurate estimate of 
the gopher tortoise population was produced (Waddle et al. 2004). The location of the gopher tortoise study is shown in Figure 38.

The American alligator, Alligator mississippiensis, is listed as a "species of special concern" by the state of Florida, and as "threatened due to similarity of appearance" by the U.S. Fish and Wildlife Service. Alligators are widespread throughout the park and 16 individuals were found during our VES (Figure 23). The American crocodile, Crocodylus acutus, is listed as "endangered" by both the state of Florida and the U.S. Fish and Wildlife Service. The species was encountered opportunistically within the park, near the Flamingo boat ramps (Figure 30).

\section{Discussion}

This study represents the first thorough inventory of amphibian species in Everglades National Park. It builds on the work previously done Duellman and Schwartz (1958), Dalrymple (1988), and Meshaka et al. (2000), and updates the list of species known from the park. This study also provides information about the relative importance of the different habitats in the park to each species, and provides a much clearer idea of the distribution of each species geographically throughout the park at the present time. We believe, however, that the greatest value of this work is as a baseline for comparison in future monitoring efforts.

One of the goals of this project was to determine if there was evidence of decline in any of the native species of amphibians. No species of amphibian currently known to be present in EVER appears to be declining due to anthropogenic or unknown factors. This is encouraging given the apparent declines of many amphibian species in protected areas worldwide (Alford and Richards 1999). There was one species, the Everglades dwarf siren (Pseudobranchus axanthus 
belli), that was not detected during this study, but it is thought to have always occurred in low abundance (Meshaka et al. 2000), and our sampling may not have been sufficient for detection. Without further investigation it is impossible to determine if the dwarf siren is declining or just occurs in a naturally low density in EVER. There has been one historical decline of a south Florida amphibian. The eastern spadefoot toad (Scaphiophus holbrooki) was collected in the region during the 1950s, but none have been observed in south Florida in the last four decades. Whatever caused that species' distribution to recede further north has apparently not affected any of the other native amphibians.

Although we did not find any evidence of declines among the amphibian species in EVER, we do not believe that this means all the amphibian species are without threats. We have identified several potential threats to the amphibian fauna in EVER. One of the most acute problems is invasive species, especially the Cuban treefrog (Osteopilus septentrionalis). This species reaches very high densities at some sites, especially near Flamingo and in Long Pine Key, and it takes a variety of vertebrate prey (Meshaka 2001, Maskell et al. 2003). The impact to the native treefrog assemblage is under investigation, but it appears that the combination of direct and indirect competition and predation allows Cuban treefrogs to increase to the detriment of native species (Rice et al., in prep.). The giant toad (Bufo marinus) is another introduced species that appears to be expanding its range in the park. This species is also a voracious predator, and although it is relatively rare in the natural areas of south Florida now, it may be increasing in abundance and expanding its range.

Other threats to the amphibian species in EVER come from changes to the aquatic environment. Levels of mercury in pig frogs collected from the park are much higher than those 
from adjacent Water Conservation Areas (C. Ugarte, Florida International University, pers. comm..). The effect of mercury on amphibians is not well known, but may warrant more research. Changes in hydrology from water management outside of the park is another impact to the aquatic environment that may be affecting amphibians. Research to identify the effects of changes in hydropattern and to make predictions about the expected shift in the amphibian community during Everglades restoration is currently underway. Finally, disease is a concern for some amphibian species in EVER. Some sick individuals were observed during this study and at least one specimen of Hyla cinerea tested positive for a strain of ranavirus (D. Green, unpublished data). No major die-offs have been detected to date in EVER, but managers should remain vigilant and report any detection of large numbers of dead or diseased frogs.

The fact that no amphibian species appears to be declining and that none of the potential threats to amphibians appear to be overwhelming is very encouraging news for managers of EVER. This inventory was designed to serve as a baseline for future monitoring efforts that will ensure that no amphibian species declines will be unnoticed. The data collected during these surveys serve as a snapshot of amphibian species distribution among habitats and across the National Park in 2000-2002. The PAO technique that was employed in this study provides a robust estimate of the true number of sites occupied given that not all species are perfectly detectable. Surveys conducted in a similar manner in the future will be directly comparable because the issue of detectability is explicitly addressed in the analysis (MacKenzie et al. 2002).

We recommend that follow-up surveys be conducted on a 5-10 year basis. The surveys should use both VES and vocalization techniques in the field, as neither method alone was sufficient for all species. Sites should be chosen randomly throughout the park and stratified by 
habitat. Habitat was one of the most important variables in modeling site occupancy. Sampling may be conducted just during the warmer, wetter months for maximum efficiency; very little information was added by including the winters in this study. Estimates of proportion of sites occupied with confidence intervals from future monitoring can be directly compared to the estimates from this study. For example, an increase in psi of 0.2 would be interpreted as a $20 \%$ increase in the number of sites occupied, or vice versa. Although these methods do not allow an estimate of the absolute abundance of amphibians, they do provide a convenient surrogate: the abundance of sites occupied by each species. This number is more easily obtained and comparable across time and among different sampling techniques.

\section{Acknowledgments}

We are grateful to all of the technicians who worked diligently to help collect data in the often uncomfortable field conditions of South Florida: Melanie Caudill, Amber Dove, Adam Finger, Victoria Foster, Phil George, Stan Howarter, and Andy Maskell. Bill Loftus (USGS) graciously allowed us to use his drift fence arrays to capture herps, and Tom Smith III (USGS) allowed us to use his mangrove "boardwalks" as study sites. The staff at the Daniel Beard Research Center in Everglades National Park provided invaluable support throughout the project, and the National Park Service provided the funding to make this project possible.

\section{Literature Cited}

Alford, R. A., and S. J. Richards. 1999. Global amphibian declines: a problem in applied ecology. Annual Review of Ecology and Systematics 30:133-165. 
Boughton, R. G., J. Staiger, and R. Franz. 2000. Use of PVC pipe refugia as a sampling technique for hylid treefrogs. American Midland Naturalist 144:168-177.

Burnham, K. P., and D. R. Anderson. 1998. Model selection and multi-model inference: a practical information-theoretic approach. Springer-Verlag, New York, NY, USA.

Carey, C., and C. J. Bryant. 1995. Possible interrelations among environmental toxicants, amphibian development, and decline of amphibian populations. Environmental Health Perspectives 103:13-17.

Conant, R., and J. T. Collins. 1991. A field guide to reptiles and amphibians: eastern and central North America, 3 edition. Houghton Mifflin Company.

Dalrymple, G. H. 1988. The herpetofauna of Long Pine Key, Everglades National Park, in relation to vegetation and hydrology. Pages 72-86 in R. C. Szaro, K. E. Severson, and D. R. Patton, editors. Management of amphibians, reptiles, and small mammals in North America. USDA Forest Service, Flagstaff, AZ.

Dodd Jr., C. K., and B. S. Cade. 1998. Movement patterns and the conservation of amphibians breeding in small, temporary wetlands. Conservation Biology 12:331-339.

Duellman, W. E., and A. Schwartz. 1958. Amphibians and reptiles of southern Florida. Bulletin of the Florida State Museum 3:179-324.

Heyer, W. R., M. A. Donnelly, R. W. McDiarmid, L. C. Hayek, and M. S. Foster. 1994. Measuring and monitoring biological diversity: standard methods for amphibians. Smithsonian Institution Press, Washington, DC. 
Hooge, P. N., and B. Eichenlaub. 1997. Animal movement extension to ArcView. in. Alaska Science Center - Biological Science Office, U.S Geological Survey, Anchorage, AK, USA.

MacKenzie, D. I., J. D. Nichols, J. E. Hines, M. G. Knutson, and A. B. Franklin. 2003. Estimating site occupancy, colonization, and local extinction when a species is detected imperfectly. Ecology 84:2200-2207.

MacKenzie, D. I., J. D. Nichols, G. B. Lachman, S. Droege, J. A. Royle, and C. A. Langtimm. 2002. Estimating site occupancy rates when detection probabilities are less than one. Ecology 83:2248-2256.

Madden, M., D. Jones, and L. Vilchek. 1999. Photointerpretation key for the Everglades vegetation classification system. Photogrammetric Engineering \& Remote Sensing $65: 171-177$.

Maskell, A. J., J. H. Waddle, and K. G. Rice. 2003. Osteopilus septentrionalis: Diet. Herpetological Review 34:137.

Meshaka, W. E. 2001. The Cuban treefrog in Florida. University of Florida Press, Gainesville, FL.

Meshaka, W. E., W. F. Loftus, and T. Steiner. 2000. The herpetofauna of Everglades National Park. Florida Scientist 63:84-103.

Waddle, J. H., F. J. Mazzotti, and K. G. Rice. 2004. Long term changes in abundance of gopher tortoise burrows at Cape Sable, Florida. Southeastern Naturalist in review.

Waddle, J. H., K. G. Rice, and H. F. Percival. 2003. Using personal digital assistants to collect wildlife field data. Wildlife Society Bulletin 31:306-308. 
Amphibians of Everglades National Park

\section{Tables}

Table 1: Number of sampling sites and total number of site visits by habitat.

\begin{tabular}{lcc}
\hline Habitat & $\begin{array}{c}\text { Number of } \\
\text { Sites }\end{array}$ & $\begin{array}{c}\text { Number of } \\
\text { Visits }\end{array}$ \\
\hline Cypress & 16 & 92 \\
Hardwood & 14 & 79 \\
Mangrove & 16 & 80 \\
Pineland & 17 & 98 \\
Rocky Glades & 18 & 93 \\
Slough & 29 & 103 \\
Borrow Pit/Canal & 4 & 9 \\
Building/Road & 4 & 8 \\
\hline Total & 118 & 562 \\
\hline
\end{tabular}


Table 2: The 27 models chosen for testing with each species in program PRESENCE.

\begin{tabular}{ll}
\hline Psi parameters & $p$ parameters \\
\hline (intercept only) & (intercept only) \\
(intercept only) & 4 Season, Water (intercept) \\
(intercept only) & 4 Seasons (no intercept) \\
(intercept only) & Humid (intercept) \\
(intercept only) & Temp (intercept) \\
(intercept only) & Temp, 4 season, (intercept) \\
(intercept only) & Temp, Humid, Water (intercept) \\
(intercept only) & Temp, Water (intercept) \\
(intercept only) & Water (intercept) \\
2 Habitats (no intercept) & (intercept only) \\
2 Habitats (no intercept) & 4 Season, Water (intercept) \\
2 Habitats (no intercept) & 4 Seasons (no intercept) \\
2 Habitats (no intercept) & Humid (intercept) \\
2 Habitats (no intercept) & Temp (intercept) \\
2 Habitats (no intercept) & Temp, 4 season, (intercept) \\
2 Habitats (no intercept) & Temp, Humid, Water (intercept) \\
2 Habitats (no intercept) & Temp, Water (intercept) \\
2 Habitats (no intercept) & Water (intercept) \\
6 Habitats (no intercept) & (intercept only) \\
6 Habitats (no intercept) & 4 Season, Water (intercept) \\
6 Habitats (no intercept) & 4 Seasons (no intercept) \\
6 Habitats (no intercept) & Humid (intercept) \\
6 Habitats (no intercept) & Temp (intercept) \\
6 Habitats (no intercept) & Temp, 4 season, (intercept) \\
6 Habitats (no intercept) & Temp, Humid, Water (intercept) \\
6 Habitats (no intercept) & Temp, Water (intercept) \\
6 Habitats (no intercept) & Water (intercept) \\
\hline
\end{tabular}


Table 3: Mean and range of snout-vent length of amphibians measured during visual encounter survey.

\begin{tabular}{lrrr}
\hline \multicolumn{1}{c}{ Species } & $\begin{array}{c}\text { Number of } \\
\text { Individuals }\end{array}$ & $\begin{array}{c}\text { Mean Snout-Vent } \\
\text { Length (+/- SD) }\end{array}$ & $\begin{array}{c}\text { Range of Snout-Vent } \\
\text { Length (mm) }\end{array}$ \\
\hline Acris gryllus & 37 & $15.02(+/-3.61)$ & $10-23$ \\
Bufo marinus & 0 & N/A & N/A \\
Bufo quercicus & 1 & $16(+/-0)$ & $16-16$ \\
Bufo terrestris & 6 & $58.33(+/-22.75)$ & $40-100$ \\
Eleutherodactylus planirostris & 3 & $21.33(+/-2.31)$ & $20-24$ \\
Gastrophryne carolinensis & 1 & $22(+/-0)$ & $22-22$ \\
Hyla cinerea & 838 & $27.69(+/-6.12)$ & $12-57$ \\
Hyla squirella & 65 & $20.88(+/-4.09)$ & $12-32$ \\
Osteopilus septentrionalis & 65 & $43.83(+/-15.32)$ & $12-83$ \\
Pseudacris nigrita & 1 & $25(+/-0)$ & $25-25$ \\
Pseudacris ocularis & 0 & N/A & N/A \\
Rana grylio & 35 & $61.77(+/-27.67)$ & $23-109$ \\
Rana sphenocephala & 37 & $50.14(+/-16.87)$ & $25-89$ \\
Amphiuma means & 0 & N/A & N/A \\
Notophthalmus viridescens & 1 & $41(+/-0)$ & $41-41$ \\
Pseudobranchus axanthus & 0 & N/A & N/A \\
Siren intermedia & 0 & N/A & N/A \\
Siren lacertina & 0 & N/A
\end{tabular}


Table 4: Number of individual Acris gryllus captured and number of site visits during which at least one A. gryllus was heard vocalizing by habitat.

\begin{tabular}{rrrr}
\hline Habitat & $\begin{array}{c}\text { Individual } \\
\text { Captures }\end{array}$ & $\begin{array}{c}\text { Visits with vocalization } \\
\text { detected }\end{array}$ & \multicolumn{2}{c}{$\begin{array}{c}\text { Number of } \\
\text { Visits }\end{array}$} \\
\hline Cypress & 6 & 37 & 92 \\
Hardwood & 21 & 13 & 79 \\
Mangrove & 0 & 1 & 80 \\
Pineland & 8 & 7 & 98 \\
Rocky Glades & 2 & 23 & 93 \\
Slough & 45 & 55 & 103 \\
Borrow & 2 & 2 & 9 \\
Pit/Canal & & & \\
Building/Road & 0 & 2 & 862 \\
\hline Total & 84 & 140 & 562 \\
\hline
\end{tabular}


Table 5: Number of individual Bufo marinus captured and number of site visits during which at least one $B$. marinus was heard vocalizing by habitat.

\begin{tabular}{rrrrr}
\hline \multicolumn{1}{c}{ Habitat } & $\begin{array}{c}\text { Individual } \\
\text { Captures }\end{array}$ & $\begin{array}{c}\text { Visits with vocalization } \\
\text { detected }\end{array}$ & \multicolumn{2}{c}{$\begin{array}{c}\text { Vumber of } \\
\text { Visits }\end{array}$} \\
\hline Cypress & 0 & 2 & 92 \\
Hardwood & 0 & 1 & 79 \\
Mangrove & 0 & 4 & 80 \\
Pineland & 0 & 3 & 98 \\
Rocky Glades & 0 & 2 & 93 \\
Slough & 0 & 1 & 103 \\
Borrow & 0 & 0 & 9 \\
Pit/Canal & & & 8 \\
Building/Road & 0 & 0 & 562 \\
\hline Total & 0 & 13 & \\
\hline
\end{tabular}


Table 6: Number of individual Bufo quercicus captured and number of site visits during which at least one B. quercicus was heard vocalizing by habitat.

\begin{tabular}{rrrrr}
\hline \multicolumn{1}{c}{ Habitat } & $\begin{array}{c}\text { Individual } \\
\text { Captures }\end{array}$ & $\begin{array}{c}\text { Visits with vocalization } \\
\text { detected }\end{array}$ & \multicolumn{2}{c}{$\begin{array}{c}\text { Vumber of } \\
\text { Visits }\end{array}$} \\
\hline Cypress & 0 & 0 & 92 \\
Hardwood & 0 & 0 & 79 \\
Mangrove & 0 & 0 & 80 \\
Pineland & 0 & 2 & 98 \\
Rocky Glades & 1 & 0 & 93 \\
Slough & 0 & 0 & 103 \\
Borrow & 0 & 2 & 9 \\
Pit/Canal & & & 8 \\
Building/Road & 0 & 0 & 562 \\
\hline Total & 1 & 4 & \\
\hline
\end{tabular}


Table 7: Number of individual Bufo terrestris captured and number of site visits during which at least one $B$. terrestris was heard vocalizing by habitat.

\begin{tabular}{rrrrr}
\hline \multicolumn{1}{c}{ Habitat } & $\begin{array}{c}\text { Individual } \\
\text { Captures }\end{array}$ & $\begin{array}{c}\text { Visits with vocalization } \\
\text { detected }\end{array}$ & \multicolumn{2}{c}{$\begin{array}{c}\text { Vumber of } \\
\text { Visits }\end{array}$} \\
\hline Cypress & 0 & 0 & 92 \\
Hardwood & 2 & 0 & 79 \\
Mangrove & 2 & 3 & 80 \\
Pineland & 2 & 7 & 98 \\
Rocky Glades & 1 & 3 & 93 \\
Slough & 1 & 0 & 103 \\
Borrow & 0 & 1 & 9 \\
Pit/Canal & & 1 & 8 \\
Building/Road & 2 & 15 & 562 \\
\hline Total & 10 & & & \\
\hline
\end{tabular}


Table 8: Number of individual Eleuthrodactylus planirostris captured and number of site visits during which at least one E. planirostris was heard vocalizing by habitat.

\begin{tabular}{rrrrr}
\hline \multicolumn{1}{c}{ Habitat } & $\begin{array}{c}\text { Individual } \\
\text { Captures }\end{array}$ & $\begin{array}{c}\text { Visits with vocalization } \\
\text { detected }\end{array}$ & \multicolumn{2}{c}{$\begin{array}{c}\text { Vumber of } \\
\text { Visits }\end{array}$} \\
\hline Cypress & 0 & 0 & 92 \\
Hardwood & 3 & 7 & 79 \\
Mangrove & 0 & 8 & 80 \\
Pineland & 6 & 8 & 98 \\
Rocky Glades & 1 & 2 & 93 \\
Slough & 0 & 0 & 103 \\
Borrow & 0 & 0 & 9 \\
Pit/Canal & & 0 & 8 \\
Building/Road & 0 & 25 & 562 \\
\hline Total & 10 & & & \\
\hline
\end{tabular}


Table 9: Number of individual Gastrophryne carolinensis captured and number of site visits during which at least one $G$. carolinensis was heard vocalizing by habitat.

\begin{tabular}{rccrr}
\hline \multicolumn{1}{c}{ Habitat } & $\begin{array}{c}\text { Individual } \\
\text { Captures }\end{array}$ & $\begin{array}{c}\text { Visits with vocalization } \\
\text { detected }\end{array}$ & \multicolumn{2}{c}{$\begin{array}{c}\text { Number of } \\
\text { Visits }\end{array}$} \\
\hline Cypress & 1 & 4 & 92 \\
Hardwood & 2 & 3 & 79 \\
Mangrove & 1 & 3 & 80 \\
Pineland & 1 & 4 & 98 \\
Rocky Glades & 0 & 3 & 93 \\
Slough & 1 & 1 & 103 \\
Borrow & 0 & 3 & 9 \\
Pit/Canal & & & \\
Building/Road & 1 & 1 & 862 \\
\hline Total & 7 & 22 & 5 \\
\hline
\end{tabular}


Amphibians of Everglades National Park

Table 10: Number of individual Hyla cinerea captured and number of site visits during which at least one $H$. cinerea was heard vocalizing by habitat.

\begin{tabular}{rrrrr}
\hline \multicolumn{1}{c}{ Habitat } & $\begin{array}{c}\text { Individual } \\
\text { Captures }\end{array}$ & $\begin{array}{c}\text { Visits with vocalization } \\
\text { detected }\end{array}$ & \multicolumn{2}{c}{$\begin{array}{c}\text { Number of } \\
\text { Visits }\end{array}$} \\
\hline Cypress & 227 & 30 & 92 \\
Hardwood & 156 & 15 & 79 \\
Mangrove & 41 & 15 & 80 \\
Pineland & 48 & 22 & 98 \\
Rocky Glades & 226 & 29 & 93 \\
Slough & 427 & 33 & 103 \\
Borrow & 2 & 3 & 9 \\
Pit/Canal & 22 & 4 & 8 \\
Building/Road & 1149 & 151 & 562 \\
\hline Total & & & \\
\hline
\end{tabular}


Table 11: Number of individual Hyla squirella captured and number of site visits during which at least one $H$. squirella was heard vocalizing by habitat.

\begin{tabular}{rrrrr}
\hline \multicolumn{1}{c}{ Habitat } & $\begin{array}{c}\text { Individual } \\
\text { Captures }\end{array}$ & $\begin{array}{c}\text { Visits with vocalization } \\
\text { detected }\end{array}$ & \multicolumn{2}{c}{$\begin{array}{c}\text { Vumber of } \\
\text { Visits }\end{array}$} \\
\hline Cypress & 25 & 5 & 92 \\
Hardwood & 2 & 3 & 79 \\
Mangrove & 7 & 2 & 80 \\
Pineland & 31 & 5 & 98 \\
Rocky Glades & 28 & 4 & 93 \\
Slough & 4 & 0 & 103 \\
Borrow & 1 & 0 & 9 \\
Pit/Canal & & 0 & 8 \\
Building/Road & 10 & 19 & 562 \\
\hline Total & 108 & & & \\
\hline
\end{tabular}


Table 12: Number of individual Osteopilus septentrionalis captured and number of site visits during which at least one $O$. septentrionalis was heard vocalizing by habitat.

\begin{tabular}{rrrrr}
\hline \multicolumn{1}{c}{ Habitat } & $\begin{array}{c}\text { Individual } \\
\text { Captures }\end{array}$ & $\begin{array}{c}\text { Visits with vocalization } \\
\text { detected }\end{array}$ & \multicolumn{2}{c}{$\begin{array}{c}\text { Vumber of } \\
\text { Visits }\end{array}$} \\
\hline Cypress & 7 & 2 & 92 \\
Hardwood & 9 & 3 & 79 \\
Mangrove & 47 & 3 & 80 \\
Pineland & 29 & 1 & 98 \\
Rocky Glades & 0 & 0 & 93 \\
Slough & 0 & 1 & 103 \\
Borrow & 0 & 0 & 9 \\
Pit/Canal & 6 & 0 & 8 \\
Building/Road & 98 & 10 & 562 \\
\hline Total & & & & \\
\hline
\end{tabular}


Table 13: Number of individual Pseudacris nigrita captured and number of site visits during which at least one $P$. nigrita was heard vocalizing by habitat.

\begin{tabular}{rrrrr}
\hline \multicolumn{1}{c}{ Habitat } & $\begin{array}{c}\text { Individual } \\
\text { Captures }\end{array}$ & $\begin{array}{c}\text { Visits with vocalization } \\
\text { detected }\end{array}$ & \multicolumn{2}{c}{$\begin{array}{c}\text { Vumber of } \\
\text { Visits }\end{array}$} \\
\hline Cypress & 0 & 0 & 92 \\
Hardwood & 0 & 2 & 79 \\
Mangrove & 0 & 0 & 80 \\
Pineland & 7 & 4 & 98 \\
Rocky Glades & 0 & 2 & 93 \\
Slough & 0 & 0 & 103 \\
Borrow & 0 & 0 & 9 \\
Pit/Canal & & 0 & 8 \\
Building/Road & 0 & 8 & 562 \\
\hline Total & 7 & & & \\
\hline
\end{tabular}


Table 14: Number of individual Pseudacris ocularis captured and number of site visits during which at least one $P$. ocularis was heard vocalizing by habitat.

\begin{tabular}{|c|c|c|c|}
\hline Habitat & $\begin{array}{c}\text { Individual } \\
\text { Captures }\end{array}$ & $\begin{array}{l}\text { Visits with vocalization } \\
\text { detected }\end{array}$ & $\begin{array}{c}\text { Number of } \\
\text { Visits }\end{array}$ \\
\hline Cypress & 1 & 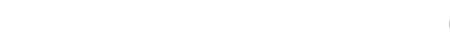 & 92 \\
\hline Hardwood & 0 & & 79 \\
\hline Mangrove & 0 & & 80 \\
\hline Pineland & 3 & & 98 \\
\hline Rocky Glades & 0 & & 93 \\
\hline Slough & 1 & & 103 \\
\hline Borrow & 0 & & 9 \\
\hline Pit/Canal & & & \\
\hline Building/Road & 0 & ( & 8 \\
\hline Total & 5 & 7 & 562 \\
\hline
\end{tabular}


Table 15: Number of individual Rana grylio captured and number of site visits during which at least one $R$. grylio was heard vocalizing by habitat.

\begin{tabular}{rrrr}
\hline Habitat & $\begin{array}{c}\text { Individual } \\
\text { Captures }\end{array}$ & $\begin{array}{c}\text { Visits with vocalization } \\
\text { detected }\end{array}$ & \multicolumn{2}{c}{$\begin{array}{c}\text { Number of } \\
\text { Visits }\end{array}$} \\
\hline Cypress & 43 & 32 & 92 \\
Hardwood & 12 & 21 & 79 \\
Mangrove & 3 & 8 & 80 \\
Pineland & 0 & 5 & 98 \\
Rocky Glades & 5 & 25 & 93 \\
Slough & 57 & 57 & 103 \\
Borrow & 1 & 2 & 9 \\
Pit/Canal & & 3 & 8 \\
Building/Road & 0 & 153 & 562 \\
\hline Total & 121 & &
\end{tabular}


Table 16: Number of individual Rana sphenocephala captured and number of site visits during which at least one $R$. sphenocephala was heard vocalizing by habitat.

\begin{tabular}{rrrrr}
\hline Habitat & $\begin{array}{c}\text { Individual } \\
\text { Captures }\end{array}$ & $\begin{array}{c}\text { Visits with vocalization } \\
\text { detected }\end{array}$ & \multicolumn{2}{c}{$\begin{array}{c}\text { Number of } \\
\text { Visits }\end{array}$} \\
\hline Cypress & 54 & 9 & 92 \\
Hardwood & 33 & 4 & 79 \\
Mangrove & 3 & 0 & 80 \\
Pineland & 9 & 0 & 98 \\
Rocky Glades & 55 & 3 & 93 \\
Slough & 8 & 20 & 103 \\
Borrow & 1 & 1 & 9 \\
Pit/Canal & & & 8 \\
Building/Road & 2 & 0 & 562 \\
\hline Total & 165 & 37 & \\
\hline
\end{tabular}


Amphibians of Everglades National Park

Table 17: Months in 2001 during which Acris gryllus was detected by VES methods and vocalization.

\begin{tabular}{ccc} 
Month & VES & Vocalization \\
\hline Jan & & \\
Feb & & \\
Mar & & \\
Apr & & \\
May & $\mathrm{X}$ & $\mathrm{X}$ \\
Jun & $\mathrm{X}$ & $\mathrm{X}$ \\
Jul & $\mathrm{X}$ & $\mathrm{X}$ \\
Aug & $\mathrm{X}$ & $\mathrm{X}$ \\
Sep & $\mathrm{X}$ & $\mathrm{X}$ \\
Oct & & $\mathrm{X}$ \\
Nov & & $\mathrm{X}$ \\
Dec & & $\mathrm{X}$ \\
\hline
\end{tabular}


Amphibians of Everglades National Park

Table 18: Months in 2001 during which Bufo marinus was detected by VES methods and vocalization.

\begin{tabular}{|c|c|c|}
\hline Month & VES & Vocalization \\
\hline Jan & & \\
\hline Feb & & $\mathrm{X}$ \\
\hline Mar & & \\
\hline Apr & & \\
\hline May & & \\
\hline Jun & & \\
\hline Jul & & \\
\hline Aug & & $X$ \\
\hline Sep & & \\
\hline Oct & & \\
\hline Nov & & $X$ \\
\hline Dec & & $\mathrm{X}$ \\
\hline
\end{tabular}


Amphibians of Everglades National Park

Table 19: Months in 2001 during which Bufo quercicus was detected by VES methods and vocalization.

\begin{tabular}{ccc} 
Month & VES & Vocalization \\
\hline Jan & & \\
Feb & & \\
Mar & & \\
Apr & & \\
May & & \\
Jun & & $X$ \\
Jul & $X$ & \\
Aug & & $X$ \\
Sep & & \\
Oct & & \\
Nov & & \\
Dec & & \\
\hline
\end{tabular}


Amphibians of Everglades National Park

Table 20: Months in 2001 during which Bufo terrestris was detected by VES methods and vocalization.

\begin{tabular}{ccc} 
Month & VES & Vocalization \\
\hline Jan & & $\mathrm{X}$ \\
Feb & $\mathrm{X}$ & \\
Mar & & $\mathrm{X}$ \\
Apr & $\mathrm{X}$ & $\mathrm{X}$ \\
May & & $\mathrm{X}$ \\
Jun & & \\
Jul & & \\
Aug & $\mathrm{X}$ & $\mathrm{X}$ \\
Sep & $\mathrm{X}$ & $\mathrm{X}$ \\
Oct & $\mathrm{X}$ & \\
Nov & & \\
Dec & $\mathrm{X}$ & \\
\hline
\end{tabular}


Amphibians of Everglades National Park

Table 21: Months in 2001 during which Eleuthrodactylus planirostris was detected by VES methods and vocalization.

\begin{tabular}{ccc} 
Month & VES & Vocalization \\
\hline Jan & $\mathrm{X}$ & \\
Feb & & \\
Mar & $\mathrm{X}$ & \\
Apr & & \\
May & & $\mathrm{X}$ \\
Jun & $\mathrm{X}$ & $\mathrm{X}$ \\
Jul & $\mathrm{X}$ & $\mathrm{X}$ \\
Aug & & $\mathrm{X}$ \\
Sep & & $\mathrm{X}$ \\
Oct & $\mathrm{X}$ & \\
Nov & $\mathrm{X}$ & \\
Dec & $\mathrm{X}$ & \\
\hline
\end{tabular}


Amphibians of Everglades National Park

Table 22: Months in 2001 during which Gastrophryne carolinensis was detected by VES methods and vocalization.

\begin{tabular}{ccc} 
Month & VES & Vocalization \\
\hline Jan & & \\
Feb & & \\
Mar & $\mathrm{X}$ & \\
Apr & $\mathrm{X}$ & $\mathrm{X}$ \\
May & $\mathrm{X}$ & $\mathrm{X}$ \\
Jun & & $\mathrm{X}$ \\
Jul & & $\mathrm{X}$ \\
Aug & $\mathrm{X}$ & $\mathrm{X}$ \\
Sep & & $\mathrm{X}$ \\
Oct & $\mathrm{X}$ & \\
Nov & & \\
Dec & & \\
\hline
\end{tabular}


Amphibians of Everglades National Park

Table 23: Months in 2001 during which Hyla cinerea was detected by VES methods and vocalization.

\begin{tabular}{ccc} 
Month & VES & Vocalization \\
\hline Jan & $\mathrm{X}$ & \\
Feb & $\mathrm{X}$ & \\
Mar & $\mathrm{X}$ & $\mathrm{X}$ \\
Apr & $\mathrm{X}$ & $\mathrm{X}$ \\
May & $\mathrm{X}$ & $\mathrm{X}$ \\
Jun & $\mathrm{X}$ & $\mathrm{X}$ \\
Jul & $\mathrm{X}$ & $\mathrm{X}$ \\
Aug & $\mathrm{X}$ & $\mathrm{X}$ \\
Sep & $\mathrm{X}$ & $\mathrm{X}$ \\
Oct & $\mathrm{X}$ & \\
Nov & $\mathrm{X}$ & \\
Dec & $\mathrm{X}$ & \\
\hline
\end{tabular}


Amphibians of Everglades National Park

Table 24: Months in 2001 during which Hyla squirella was detected by VES methods and vocalization.

\begin{tabular}{ccc} 
Month & VES & Vocalization \\
\hline Jan & $\mathrm{X}$ & \\
Feb & & \\
Mar & & \\
Apr & $\mathrm{X}$ & $\mathrm{X}$ \\
May & $\mathrm{X}$ & $\mathrm{X}$ \\
Jun & & \\
Jul & $\mathrm{X}$ & $\mathrm{X}$ \\
Aug & $\mathrm{X}$ & \\
Sep & $\mathrm{X}$ & $\mathrm{X}$ \\
Oct & $\mathrm{X}$ & \\
Nov & $\mathrm{X}$ & \\
Dec & $\mathrm{X}$ & \\
\hline
\end{tabular}


Amphibians of Everglades National Park

Table 25: Months in 2001 during which Osteopilus septentrionalis was detected by VES methods and vocalization.

\begin{tabular}{ccc} 
Month & VES & Vocalization \\
\hline Jan & X & \\
Feb & X & \\
Mar & X & \\
Apr & X & X \\
May & X & X \\
Jun & X & \\
Jul & X & \\
Aug & X & X \\
Sep & X & X \\
Oct & X & X \\
Nov & X & \\
Dec & X & \\
\hline
\end{tabular}


Amphibians of Everglades National Park

Table 26: Months in 2001 during which Pseudacris nigrita was detected by VES methods and vocalization.

\begin{tabular}{ccc} 
Month & VES & Vocalization \\
\hline Jan & & \\
Feb & & \\
Mar & & \\
Apr & & \\
May & & \\
Jun & X & X \\
Jul & & \\
Aug & X & X \\
Sep & & \\
Oct & & \\
Nov & & \\
Dec & & \\
\hline
\end{tabular}


Amphibians of Everglades National Park

Table 27: Months in 2001 during which Pseudacris ocularis was detected by VES methods and vocalization.

\begin{tabular}{ccc} 
Month & VES & Vocalization \\
\hline Jan & $\mathrm{X}$ & \\
Feb & & \\
Mar & & \\
Apr & & \\
May & & \\
Jun & & \\
Jul & $\mathrm{X}$ \\
Aug & & \\
Sep & & \\
Oct & $\mathrm{X}$ & \\
Nov & & \\
Dec & & \\
\hline
\end{tabular}


Amphibians of Everglades National Park

Table 28: Months in 2001 during which Rana grylio was detected by VES methods and vocalization.

\begin{tabular}{ccc} 
Month & VES & Vocalization \\
\hline Jan & $\mathrm{X}$ & $\mathrm{X}$ \\
Feb & $\mathrm{X}$ & \\
Mar & & \\
Apr & $\mathrm{X}$ & \\
May & $\mathrm{X}$ & $\mathrm{X}$ \\
Jun & $\mathrm{X}$ & $\mathrm{X}$ \\
Jul & $\mathrm{X}$ & $\mathrm{X}$ \\
Aug & $\mathrm{X}$ & $\mathrm{X}$ \\
Sep & $\mathrm{X}$ & $\mathrm{X}$ \\
Oct & $\mathrm{X}$ & \\
Nov & $\mathrm{X}$ & $\mathrm{X}$ \\
Dec & $\mathrm{X}$ & $\mathrm{X}$ \\
\hline
\end{tabular}


Amphibians of Everglades National Park

Table 29: Months in 2001 during which Rana sphenocephala was detected by VES methods and vocalization.

\begin{tabular}{ccc} 
Month & VES & Vocalization \\
\hline Jan & $\mathrm{X}$ & $\mathrm{X}$ \\
Feb & $\mathrm{X}$ & \\
Mar & $\mathrm{X}$ & \\
Apr & $\mathrm{X}$ & \\
May & $\mathrm{X}$ & $\mathrm{X}$ \\
Jun & $\mathrm{X}$ & $\mathrm{X}$ \\
Jul & $\mathrm{X}$ & \\
Aug & $\mathrm{X}$ & $\mathrm{X}$ \\
Sep & $\mathrm{X}$ & $\mathrm{X}$ \\
Oct & $\mathrm{X}$ & $\mathrm{X}$ \\
Nov & $\mathrm{X}$ & $\mathrm{X}$ \\
Dec & $\mathrm{X}$ & $\mathrm{X}$ \\
\hline
\end{tabular}


Table 30: Average snout-vent length for Acris gryllus (found using VES and opportunistic encounter surveys) stratified by habitat.

\begin{tabular}{rrrr}
\hline \multicolumn{1}{c}{ Habitat } & $\begin{array}{c}\text { Individuals } \\
\text { Measured (N) }\end{array}$ & $\begin{array}{c}\text { Mean Snout-Vent } \\
\text { Length (mm) }\end{array}$ & Standard Deviation \\
\hline Cypress & 2 & 16.5 & 0.71 \\
Hardwood & 14 & 14.5 & 1.79 \\
Mangrove & 0 & N/A & N/A \\
Pineland & 2 & 16.5 & 9.19 \\
Rocky Glades & 0 & N/A & N/A \\
Slough & 19 & 15.11 & 4.28 \\
Borrow & 0 & N/A & N/A \\
Pit/Canal & & & \\
Building/Road & 0 & N/A & N/A \\
\hline
\end{tabular}


Table 31: Average snout-vent length for Bufo terrestris (found using VES and opportunistic encounter surveys) stratified by habitat.

\begin{tabular}{rrrr}
\hline \multicolumn{1}{c}{ Habitat } & $\begin{array}{c}\text { Individuals } \\
\text { Measured (N) }\end{array}$ & $\begin{array}{c}\text { Mean Snout-Vent } \\
\text { Length (mm) }\end{array}$ & Standard Deviation \\
\hline Cypress & 0 & 0 & 0 \\
Hardwood & 1 & 59 & 0 \\
Mangrove & 2 & 43 & 0 \\
Pineland & 1 & 100 & 0 \\
Rocky Glades & 1 & 40 & 0 \\
Slough & 1 & 65 & 0 \\
Borrow & 0 & 0 & 0 \\
Pit/Canal & & & \\
Building/Road & 0 & 0 & 0 \\
\hline
\end{tabular}


Amphibians of Everglades National Park

Table 32: Average snout-vent length for Eleuthrodactylus planirostris (found using VES and opportunistic encounter surveys) stratified by habitat.

\begin{tabular}{rrrr}
\hline \multicolumn{1}{c}{ Habitat } & $\begin{array}{c}\text { Individuals } \\
\text { Measured (N) }\end{array}$ & $\begin{array}{c}\text { Mean Snout-Vent } \\
\text { Length (mm) }\end{array}$ & Standard Deviation \\
\hline Cypress & & 20 & 0 \\
Hardwood & 1 & N/A & N/A \\
Mangrove & 0 & 22 & 2.83 \\
Pineland & 2 & N/A & N/A \\
Rocky Glades & 0 & N/A & N/A \\
Slough & 0 & N/A & N/A \\
Borrow & 0 & & N/A
\end{tabular}


Amphibians of Everglades National Park

Table 33: Average snout-vent length for Hyla cinerea (found using VES and opportunistic encounter surveys) stratified by habitat.

\begin{tabular}{rrrr}
\hline \multicolumn{1}{c}{ Habitat } & $\begin{array}{c}\text { Individuals } \\
\text { Measured (N) }\end{array}$ & $\begin{array}{c}\text { Mean Snout-Vent } \\
\text { Length (mm) }\end{array}$ & Standard Deviation \\
\hline Cypress & 170 & 30.87 & 7.31 \\
Hardwood & 127 & 27.93 & 6.44 \\
Mangrove & 29 & 29 & 6.92 \\
Pineland & 27 & 28.81 & 9.43 \\
Rocky Glades & 175 & 26.31 & 4.81 \\
Slough & 302 & 26.26 & 4.57 \\
Borrow Pit/Canal & 1 & 24 & 0 \\
Building/Road & 7 & 33.14 & 6.87 \\
\hline
\end{tabular}


Table 34: Average snout-vent length for Hyla squirella (found using VES and opportunistic encounter surveys) stratified by habitat.

\begin{tabular}{rrrr}
\hline \multicolumn{1}{c}{ Habitat } & $\begin{array}{c}\text { Individuals } \\
\text { Measured (N) }\end{array}$ & $\begin{array}{c}\text { Mean Snout-Vent } \\
\text { Length (mm) }\end{array}$ & Standard Deviation \\
\hline Cypress & 20 & 23.05 & 4.08 \\
Hardwood & 0 & N/A & N/A \\
Mangrove & 6 & 24.33 & 5.09 \\
Pineland & 11 & 19.73 & 4.2 \\
Rocky Glades & 24 & 18.5 & 1.91 \\
Slough & 3 & 20.67 & 2.31 \\
Borrow & 1 & 27 & 0 \\
Pit/Canal & & & \\
Building/Road & 0 & N/A & N/A \\
\hline
\end{tabular}


Table 35: Average snout-vent length for Osteopilus septentrionalis (found using VES and opportunistic encounter surveys) stratified by habitat.

\begin{tabular}{rrrr}
\hline \multicolumn{1}{c}{ Habitat } & $\begin{array}{c}\text { Individuals } \\
\text { Measured (N) }\end{array}$ & $\begin{array}{c}\text { Mean Snout-Vent } \\
\text { Length (mm) }\end{array}$ & Standard Deviation \\
\hline Cypress & 5 & 26 & 13.36 \\
Hardwood & 5 & 66.8 & 21.16 \\
Mangrove & 35 & 45.57 & 12.25 \\
Pineland & 18 & 37.17 & 9.57 \\
Rocky Glades & 0 & $\mathrm{~N} / \mathrm{A}$ & N/A \\
Slough & 0 & $\mathrm{~N} / \mathrm{A}$ & N/A \\
Borrow & 0 & N/A & N/A \\
Pit/Canal & & & \\
Building/Road & 2 & 60.5 & 13.44 \\
\hline
\end{tabular}


Table 36: Average snout-vent length for Rana grylio (found using VES and opportunistic encounter surveys) stratified by habitat.

\begin{tabular}{rrrr}
\hline \multicolumn{1}{c}{ Habitat } & $\begin{array}{c}\text { Individuals } \\
\text { Measured (N) }\end{array}$ & $\begin{array}{c}\text { Mean Snout-Vent } \\
\text { Length (mm) }\end{array}$ & Standard Deviation \\
\hline Cypress & 18 & 60.28 & 28.21 \\
Hardwood & 5 & 54.6 & 24.46 \\
Mangrove & 0 & $\mathrm{~N} / \mathrm{A}$ & $\mathrm{N} / \mathrm{A}$ \\
Pineland & 0 & $\mathrm{~N} / \mathrm{A}$ & $\mathrm{N} / \mathrm{A}$ \\
Rocky Glades & 1 & 45 & 0 \\
Slough & 11 & 69 & 29.93 \\
Borrow & 0 & $\mathrm{~N} / \mathrm{A}$ & $\mathrm{N} / \mathrm{A}$ \\
Pit/Canal & & & \\
Building/Road & 0 & N/A & N/A \\
\hline
\end{tabular}


Table 37: Average snout-vent length for Rana sphenocephala (found using VES and opportunistic encounter surveys) stratified by habitat.

\begin{tabular}{rrrr}
\hline \multicolumn{1}{c}{ Habitat } & $\begin{array}{c}\text { Individuals } \\
\text { Measured (N) }\end{array}$ & $\begin{array}{c}\text { Mean Snout-Vent } \\
\text { Length (mm) }\end{array}$ & Standard Deviation \\
\hline Cypress & 18 & 60.28 & 28.21 \\
Hardwood & 7 & 50 & 20.41 \\
Mangrove & 0 & $\mathrm{~N} / \mathrm{A}$ & $\mathrm{N} / \mathrm{A}$ \\
Pineland & 5 & 55.6 & 16.85 \\
Rocky Glades & 12 & 54.83 & 17.08 \\
Slough & 3 & 50.67 & 13.58 \\
Borrow & 0 & $\mathrm{~N} / \mathrm{A}$ & N/A \\
Pit/Canal & & & \\
Building/Road & 0 & N/A & N/A \\
\hline
\end{tabular}


Table 38: Number of sites sampled, sites at which Acris gryllus was detected, and the naïve site occupancy rate by habitat.

\begin{tabular}{rrrcc}
\hline Habitat & $\begin{array}{c}\text { Number of } \\
\text { Sites }\end{array}$ & $\begin{array}{c}\text { Number of Sites with } \\
\text { Detection }\end{array}$ & $\begin{array}{c}\text { Naïve Occupancy } \\
\text { Rate }\end{array}$ & PAO Estimate \\
\hline Cypress & 16 & 13 & $81.25 \%$ & $83.90 \%$ \\
Hammock & 14 & 7 & $50.00 \%$ & $84.95 \%$ \\
Mangrove & 16 & 0 & $0.00 \%$ & $0.00 \%$ \\
Pineland & 17 & 6 & $35.29 \%$ & $62.52 \%$ \\
Rocky Glades & 18 & 14 & $77.78 \%$ & $83.82 \%$ \\
Slough & 29 & 26 & $89.66 \%$ & $100.00 \%$ \\
Borrow Pit/Canal & 4 & 1 & $25.00 \%$ & NA \\
Building/Road & 4 & 2 & $50.00 \%$ & NA \\
\hline Total & 118 & 69 & $58.47 \%$ & $72.76 \%$ \\
\hline
\end{tabular}


Table 39: Number of sites sampled, sites at which Bufo quercicus was detected, and the naïve site occupancy rate by habitat.

\begin{tabular}{|c|c|c|c|c|}
\hline Habitat & $\begin{array}{l}\text { Number of } \\
\text { Sites }\end{array}$ & $\begin{array}{l}\text { Number of Sites with } \\
\text { Detection }\end{array}$ & $\begin{array}{c}\text { Naïve Occupancy } \\
\text { Rate }\end{array}$ & PAO Estimate \\
\hline Cypress & 16 & 0 & $0.00 \%$ & $0.00 \%$ \\
\hline Hammock & 14 & 0 & $0.00 \%$ & $0.00 \%$ \\
\hline Mangrove & 16 & 0 & $0.00 \%$ & $0.00 \%$ \\
\hline Pineland & 17 & 2 & $11.76 \%$ & $100.00 \%$ \\
\hline Rocky Glades & 18 & 1 & $5.56 \%$ & $60.43 \%$ \\
\hline Slough & 29 & 0 & $0.00 \%$ & $0.00 \%$ \\
\hline Borrow Pit/Canal & 4 & 0 & $0.00 \%$ & NA \\
\hline Building/Road & 4 & 2 & $50.00 \%$ & NA \\
\hline Total & 118 & 5 & $4.24 \%$ & $25.34 \%$ \\
\hline
\end{tabular}


Table 40: Number of sites sampled, sites at which Bufo terrestris was detected, and the naïve site occupancy rate by habitat.

\begin{tabular}{rrrcc}
\hline \multicolumn{1}{c}{ Habitat } & $\begin{array}{c}\text { Number of } \\
\text { Sites }\end{array}$ & $\begin{array}{c}\text { Number of Sites with } \\
\text { Detection }\end{array}$ & $\begin{array}{c}\text { Naïve Occupancy } \\
\text { Rate }\end{array}$ & PAO Estimate \\
\hline Cypress & 16 & 0 & $0.00 \%$ & $0.00 \%$ \\
Hammock & 14 & 2 & $14.29 \%$ & $48.84 \%$ \\
Mangrove & 16 & 2 & $12.50 \%$ & $47.25 \%$ \\
Pineland & 17 & 5 & $29.41 \%$ & $100.00 \%$ \\
Rocky Glades & 18 & 1 & $5.56 \%$ & $20.68 \%$ \\
Slough & 29 & 2 & $6.90 \%$ & $39.20 \%$ \\
Borrow Pit/Canal & 4 & 1 & $25.00 \%$ & NA \\
Building/Road & 4 & 1 & $25.00 \%$ & NA \\
\hline Total & 118 & 14 & $11.86 \%$ & $42.26 \%$ \\
\hline
\end{tabular}


Table 41: Number of sites sampled, sites at which Eleuthrodactylus planirostris was detected, and the naïve site occupancy rate by habitat.

\begin{tabular}{rrccc}
\hline \multicolumn{1}{c}{ Habitat } & $\begin{array}{c}\text { Number of } \\
\text { Sites }\end{array}$ & $\begin{array}{c}\text { Number of Sites with } \\
\text { Detection }\end{array}$ & $\begin{array}{c}\text { Naïve Occupancy } \\
\text { Rate }\end{array}$ & PAO Estimate \\
\hline Cypress & 16 & 0 & $0.00 \%$ & $0.00 \%$ \\
Hammock & 14 & 4 & $28.57 \%$ & $72.11 \%$ \\
Mangrove & 16 & 4 & $25.00 \%$ & $53.60 \%$ \\
Pineland & 17 & 9 & $52.94 \%$ & $100.00 \%$ \\
Rocky Glades & 18 & 2 & $11.11 \%$ & $24.71 \%$ \\
Slough & 29 & 0 & $0.00 \%$ & $0.00 \%$ \\
Borrow Pit/Canal & 4 & 0 & $0.00 \%$ & NA \\
Building/Road & 4 & 0 & $0.00 \%$ & NA \\
\hline Total & 118 & 19 & $16.10 \%$ & $36.47 \%$ \\
\hline
\end{tabular}


Table 42: Number of sites sampled, sites at which Gastrophryne carolinensis was detected, and the naïve site occupancy rate by habitat.

\begin{tabular}{rrccc}
\hline \multicolumn{1}{c}{ Habitat } & $\begin{array}{c}\text { Number of } \\
\text { Sites }\end{array}$ & $\begin{array}{c}\text { Number of Sites with } \\
\text { Detection }\end{array}$ & $\begin{array}{c}\text { Naïve Occupancy } \\
\text { Rate }\end{array}$ & PAO Estimate \\
\hline Cypress & 16 & 3 & $18.75 \%$ & $65.96 \%$ \\
Hammock & 14 & 3 & $21.43 \%$ & $66.98 \%$ \\
Mangrove & 16 & 2 & $12.50 \%$ & $40.34 \%$ \\
Pineland & 17 & 4 & $23.53 \%$ & $63.67 \%$ \\
Rocky Glades & 18 & 3 & $16.67 \%$ & $46.24 \%$ \\
Slough & 29 & 2 & $6.90 \%$ & $27.82 \%$ \\
Borrow Pit/Canal & 4 & 2 & $50.00 \%$ & NA \\
Building/Road & 4 & 3 & $75.00 \%$ & NA \\
\hline Total & 118 & 22 & $18.64 \%$ & $57.41 \%$ \\
\hline
\end{tabular}


Table 43: Number of sites sampled, sites at which Hyla cinerea was detected, and the naïve site occupancy rate by habitat.

\begin{tabular}{rrrcc}
\hline \multicolumn{1}{c}{ Habitat } & $\begin{array}{c}\text { Number of } \\
\text { Sites }\end{array}$ & $\begin{array}{c}\text { Number of Sites with } \\
\text { Detection }\end{array}$ & $\begin{array}{c}\text { Naïve Occupancy } \\
\text { Rate }\end{array}$ & PAO Estimate \\
\hline Cypress & 16 & 13 & 0.813 & $90.15 \%$ \\
Hammock & 14 & 12 & 0.857 & $95.62 \%$ \\
Mangrove & 16 & 7 & 0.438 & $48.82 \%$ \\
Pineland & 17 & 15 & 0.882 & $95.44 \%$ \\
Rocky Glades & 18 & 16 & 0.889 & $99.09 \%$ \\
Slough & 29 & 29 & 1 & $100.00 \%$ \\
Borrow Pit/Canal & 4 & 3 & 0.75 & NA \\
Building/Road & 4 & 3 & 0.75 & NA \\
\hline Total & 118 & 98 & 0.831 & $88.23 \%$ \\
\hline
\end{tabular}


Table 44: Number of sites sampled, sites at which Hyla squirella was detected, and the naïve site occupancy rate by habitat.

\begin{tabular}{rrrcc}
\hline \multicolumn{1}{c}{ Habitat } & $\begin{array}{c}\text { Number of } \\
\text { Sites }\end{array}$ & $\begin{array}{c}\text { Number of Sites with } \\
\text { Detection }\end{array}$ & $\begin{array}{c}\text { Naïve Occupancy } \\
\text { Rate }\end{array}$ & PAO Estimate \\
\hline Cypress & 16 & 8 & $50.00 \%$ & $97.13 \%$ \\
Hammock & 14 & 3 & $21.43 \%$ & $38.61 \%$ \\
Mangrove & 16 & 4 & $25.00 \%$ & $52.99 \%$ \\
Pineland & 17 & 11 & $64.71 \%$ & $94.47 \%$ \\
Rocky Glades & 18 & 6 & $33.33 \%$ & $60.86 \%$ \\
Slough & 29 & 3 & $10.34 \%$ & $24.45 \%$ \\
Borrow Pit/Canal & 4 & 1 & $25.00 \%$ & NA \\
Building/Road & 4 & 1 & $25.00 \%$ & NA \\
\hline Total & 118 & 37 & $31.36 \%$ & $57.76 \%$ \\
\hline
\end{tabular}


Table 45: Number of sites sampled, sites at which Osteopilus septentrionalis was detected, and the naïve site occupancy rate by habitat.

\begin{tabular}{rrccc}
\hline Habitat & $\begin{array}{c}\text { Number of } \\
\text { Sites }\end{array}$ & $\begin{array}{c}\text { Number of Sites with } \\
\text { Detection }\end{array}$ & $\begin{array}{c}\text { Naïve Occupancy } \\
\text { Rate }\end{array}$ & PAO Estimate \\
\hline Cypress & 16 & 3 & $18.75 \%$ & $39.31 \%$ \\
Hammock & 14 & 3 & $21.43 \%$ & $39.76 \%$ \\
Mangrove & 16 & 4 & $25.00 \%$ & $57.24 \%$ \\
Pineland & 17 & 8 & $47.06 \%$ & $100.00 \%$ \\
Rocky Glades & 18 & 0 & $0.00 \%$ & $0.00 \%$ \\
Slough & 29 & 0 & $0.00 \%$ & $0.00 \%$ \\
Borrow Pit/Canal & 4 & 2 & $50.00 \%$ & $\mathrm{NA}$ \\
Building/Road & 4 & 0 & $0.00 \%$ & $\mathrm{NA}$ \\
\hline Total & 118 & 20 & $16.95 \%$ & $34.66 \%$ \\
\hline
\end{tabular}


Table 46: Number of sites sampled, sites at which Rana grylio was detected, and the naïve site occupancy rate by habitat.

\begin{tabular}{rrrcc}
\hline \multicolumn{1}{c}{ Habitat } & $\begin{array}{c}\text { Number of } \\
\text { Sites }\end{array}$ & $\begin{array}{c}\text { Number of Sites with } \\
\text { Detection }\end{array}$ & $\begin{array}{c}\text { Naïve Occupancy } \\
\text { Rate }\end{array}$ & PAO Estimate \\
\hline Cypress & 16 & 12 & $75.00 \%$ & $77.90 \%$ \\
Hammock & 14 & 9 & $64.29 \%$ & $90.57 \%$ \\
Mangrove & 16 & 3 & $18.75 \%$ & $26.80 \%$ \\
Pineland & 17 & 4 & $23.53 \%$ & $32.92 \%$ \\
Rocky Glades & 18 & 14 & $77.78 \%$ & $90.49 \%$ \\
Slough & 29 & 27 & $93.10 \%$ & $100.00 \%$ \\
Borrow Pit/Canal & 4 & 1 & $25.00 \%$ & NA \\
Building/Road & 4 & 2 & $50.00 \%$ & NA \\
\hline Total & 118 & 72 & $61.02 \%$ & $73.01 \%$ \\
\hline
\end{tabular}


Table 47: Number of sites sampled, sites at which Rana sphenocephala was detected, and the naïve site occupancy rate by habitat.

\begin{tabular}{rrrcc}
\hline \multicolumn{1}{c}{ Habitat } & $\begin{array}{c}\text { Number of } \\
\text { Sites }\end{array}$ & $\begin{array}{c}\text { Number of Sites with } \\
\text { Detection }\end{array}$ & $\begin{array}{c}\text { Naïve Occupancy } \\
\text { Rate }\end{array}$ & PAO Estimate \\
\hline Cypress & 16 & 6 & $37.50 \%$ & $68.22 \%$ \\
Hammock & 14 & 6 & $42.86 \%$ & $76.18 \%$ \\
Mangrove & 16 & 3 & $18.75 \%$ & $35.16 \%$ \\
Pineland & 17 & 4 & $23.53 \%$ & $38.22 \%$ \\
Rocky Glades & 18 & 12 & $66.67 \%$ & $100.00 \%$ \\
Slough & 29 & 12 & $41.38 \%$ & $75.73 \%$ \\
Borrow Pit/Canal & 4 & 2 & $50.00 \%$ & NA \\
Building/Road & 4 & 2 & $50.00 \%$ & NA \\
\hline Total & 118 & 47 & $39.83 \%$ & $71.48 \%$ \\
\hline
\end{tabular}


Table 48: Numbers of individual caudates captured by different survey methods.

\begin{tabular}{lrrrr}
\hline Survey Method & $\begin{array}{r}\text { Amphiuma } \\
\text { means }\end{array}$ & $\begin{array}{r}\text { Notophthalmus } \\
\text { viridescens }\end{array}$ & $\begin{array}{r}\text { Pseudobranchus } \\
\text { axanthus }\end{array}$ & Siren lacertina \\
\hline Drift Fence & 22 & 3 & 0 & 19 \\
Funnel Trap & 2 & 2 & 0 & 4 \\
VES & 13 & 7 & 0 & 7 \\
Opportunistic & 0 & 0 & 0 & \\
Encounter & 37 & 12 & 0 & 30 \\
Total & & & & \\
\hline
\end{tabular}


Table 49: Reptile species found in Everglades National Park and the survey methods by which they were detected

\begin{tabular}{|c|c|c|c|c|c|c|}
\hline Class & Species & Common Name & $\begin{array}{l}\text { Opportunistic } \\
\text { Encounter }\end{array}$ & VES & $\begin{array}{c}\text { Funnel } \\
\text { Trap }\end{array}$ & $\begin{array}{l}\text { Drift } \\
\text { Fence }\end{array}$ \\
\hline \multirow[t]{2}{*}{ Crocodilians } & Alligator mississippiensis & American alligator & & $\mathrm{X}$ & & \\
\hline & Crocodylus acutus & American crocodile & $\mathrm{X}$ & & & \\
\hline \multirow[t]{6}{*}{ Lizards } & Anolis carolinensis & green anole & & $\mathrm{X}$ & & \\
\hline & Anolis sagrei & brown anole & $\mathrm{X}$ & $\mathrm{X}$ & & \\
\hline & Eumeces inexpectatus & southeastern five-lined skink & $\mathrm{X}$ & & & \\
\hline & Hemidactylus mabouia & tropical house gecko & $\mathrm{X}$ & $\mathrm{X}$ & & \\
\hline & Ophisaurus compressus & island glass lizard & $\mathrm{X}$ & & & \\
\hline & Scincella lateralis & ground skink & & & & $\mathrm{X}$ \\
\hline \multirow[t]{20}{*}{ Snakes } & Agkistrodon piscivorus conanti & Florida cottonmouth & $\mathrm{X}$ & & & $\mathrm{X}$ \\
\hline & Cemophora coccinea coccinea & Florida scarlet snake & $\mathrm{X}$ & & & \\
\hline & Coluber constrictor paludicola & Everglades racer & $\mathrm{X}$ & & & $\mathrm{X}$ \\
\hline & Crotalus adamanteus & eastern diamondback rattlesnake & $\mathrm{X}$ & $\mathrm{X}$ & & \\
\hline & Diadophis punctatus punctatus & southern ringneck snake & $\mathrm{X}$ & & & \\
\hline & Elaphe guttata guttata & corn snake & & $\mathrm{X}$ & & \\
\hline & Elaphe obsoleta quadrivittata & yellow rat snake & $\mathrm{X}$ & & & $\mathrm{X}$ \\
\hline & Farancia abacura abacura & eastern mud snake & $\mathrm{X}$ & & & \\
\hline & Lampropeltis getula floridana & Florida kingsnake & $\mathrm{X}$ & & & \\
\hline & Nerodia clarkii compressicauda & mangrove salt marsh snake & $\mathrm{X}$ & & & \\
\hline & Nerodia fasciata pictiventris & Florida water snake & $\mathrm{X}$ & $\mathrm{X}$ & $\mathrm{X}$ & $\mathrm{X}$ \\
\hline & Nerodia floridana & Florida green water snake & $\mathrm{X}$ & $\mathrm{X}$ & $\mathrm{X}$ & \\
\hline & Nerodia taxispilota & brown water snake & & $\mathrm{X}$ & & \\
\hline & Opheodrys aestivus & rough green snake & $\mathrm{X}$ & & & \\
\hline & Python molorus bivittatus & Burmese python & $\mathrm{X}$ & & & \\
\hline & Regina alleni & striped crayfish snake & & $\mathrm{X}$ & & $\mathrm{X}$ \\
\hline & Sistrurus miliarius barbouri & dusky pigmy rattlesnake & $\mathrm{X}$ & & & \\
\hline & Storeria dekayi victa & Florida brown snake & & $\mathrm{X}$ & & \\
\hline & Thamnophis sauritus sackenii & peninsula ribbon snake & $\mathrm{X}$ & $\mathrm{X}$ & & $\mathrm{X}$ \\
\hline & Thamnophis sirtalis sirtalis & eastern garter snake & $\mathrm{X}$ & $\mathrm{X}$ & & $\mathrm{X}$ \\
\hline
\end{tabular}




\section{Amphibians of Everglades National Park}

\begin{tabular}{|c|c|c|c|c|c|c|}
\hline Class & Species & Common Name & $\begin{array}{l}\text { Opportunistic } \\
\text { Encounter }\end{array}$ & VES & $\begin{array}{c}\text { Funnel } \\
\text { Trap }\end{array}$ & $\begin{array}{l}\text { Drift } \\
\text { Fence }\end{array}$ \\
\hline \multirow[t]{9}{*}{ Turtles } & Apolone ferox & Florida softshell turtle & & $\mathrm{X}$ & & \\
\hline & Chelydra serpentina osceola & Florida snapping turtle & $\mathrm{X}$ & & & \\
\hline & Deirochelys reticularia chrysea & Florida chicken turtle & $\mathrm{X}$ & & & \\
\hline & Gopherus polyphemus & gopher tortoise & $\mathrm{X}$ & & & \\
\hline & $\begin{array}{l}\text { Kinosternon baurii } \\
\text { Kinosternon subrubrum }\end{array}$ & striped mud turtle & $\mathrm{X}$ & $\mathrm{X}$ & & $\mathrm{X}$ \\
\hline & steindachneri & Florida mud turtle & $\mathrm{X}$ & & & \\
\hline & Pseudemys floridana peninsularis & peninsula cooter & $\mathrm{X}$ & & & \\
\hline & Pseudemys nelsoni & Florida redbelly turtle & $\mathrm{X}$ & & & \\
\hline & Terrapene carolina baurii & Florida box turtle & & $\mathrm{X}$ & & $\mathrm{X}$ \\
\hline
\end{tabular}


Amphibians of Everglades National Park

\section{Figures}

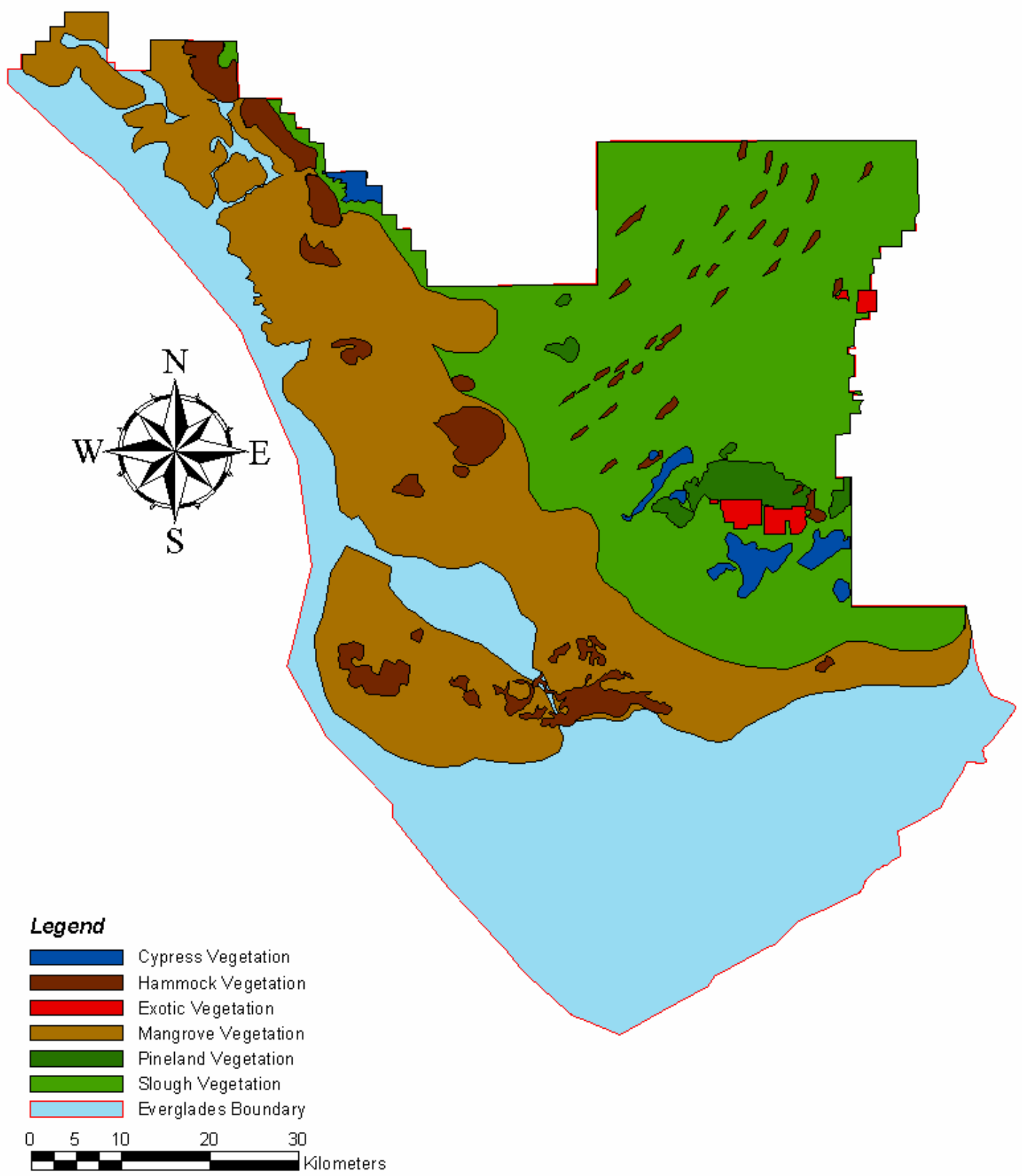

Figure 1: Vegetation classification of Everglades National Park 
Amphibians of Everglades National Park

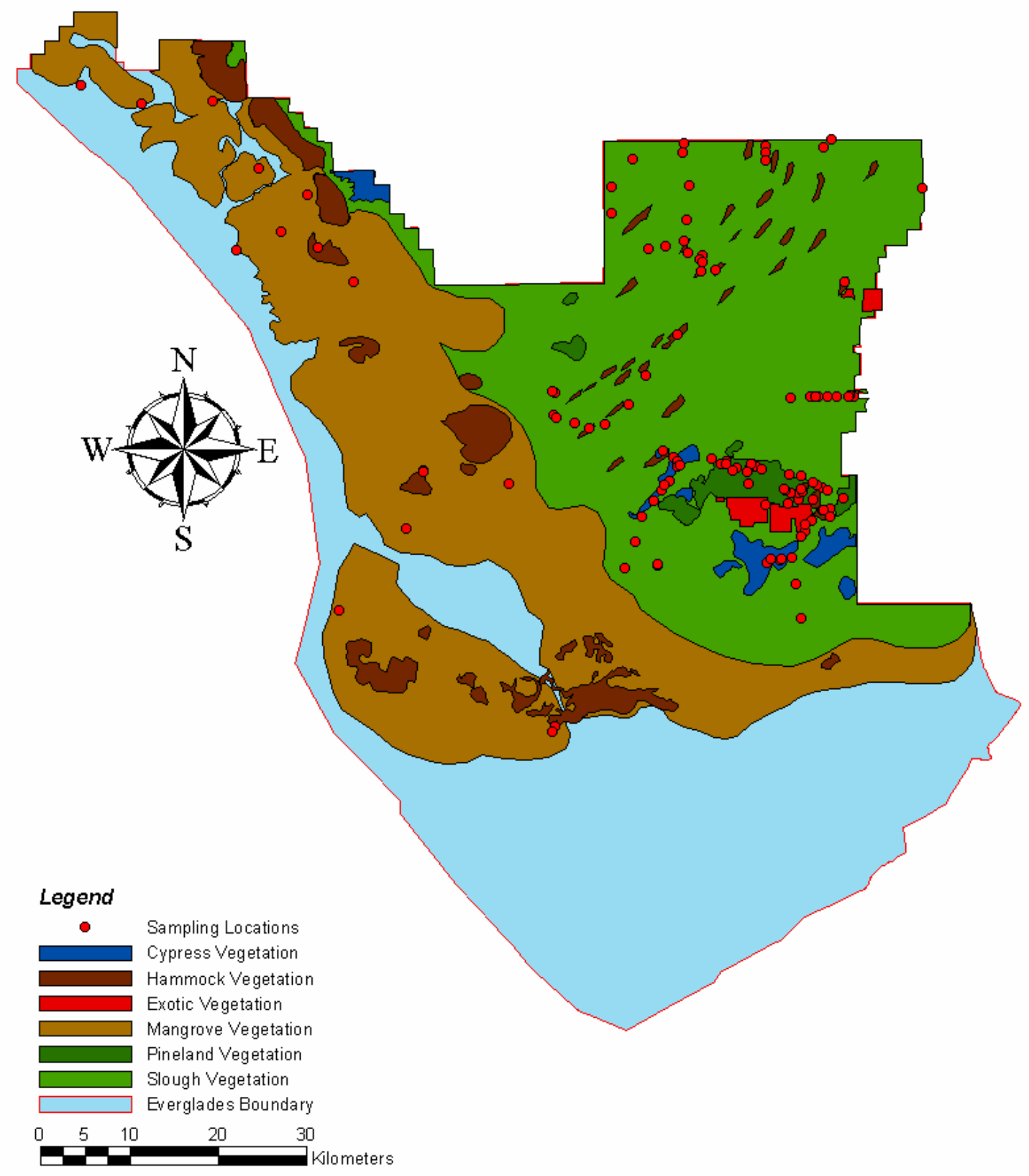

Figure 2: Standard sampling site locations

Map of all Standard Sampling locations at which VES and Vocalization surveys were conducted at Everglades National Park. 
Amphibians of Everglades National Park

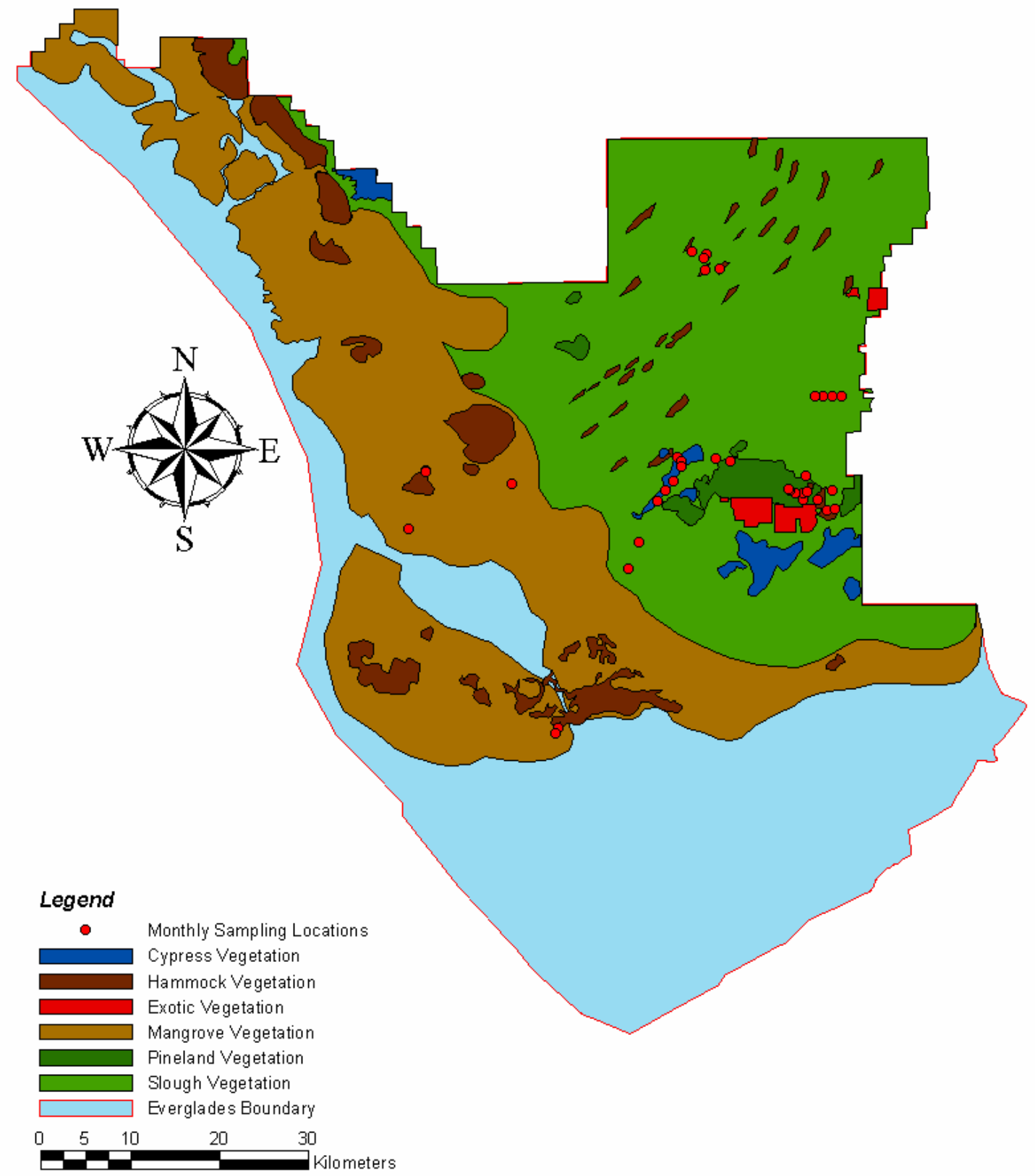

Figure 3: Sites sampled on a monthly basis

Map of all locations at which VES and Vocalization surveys were conducted on a monthly basis at Everglades National Park. 
Amphibians of Everglades National Park

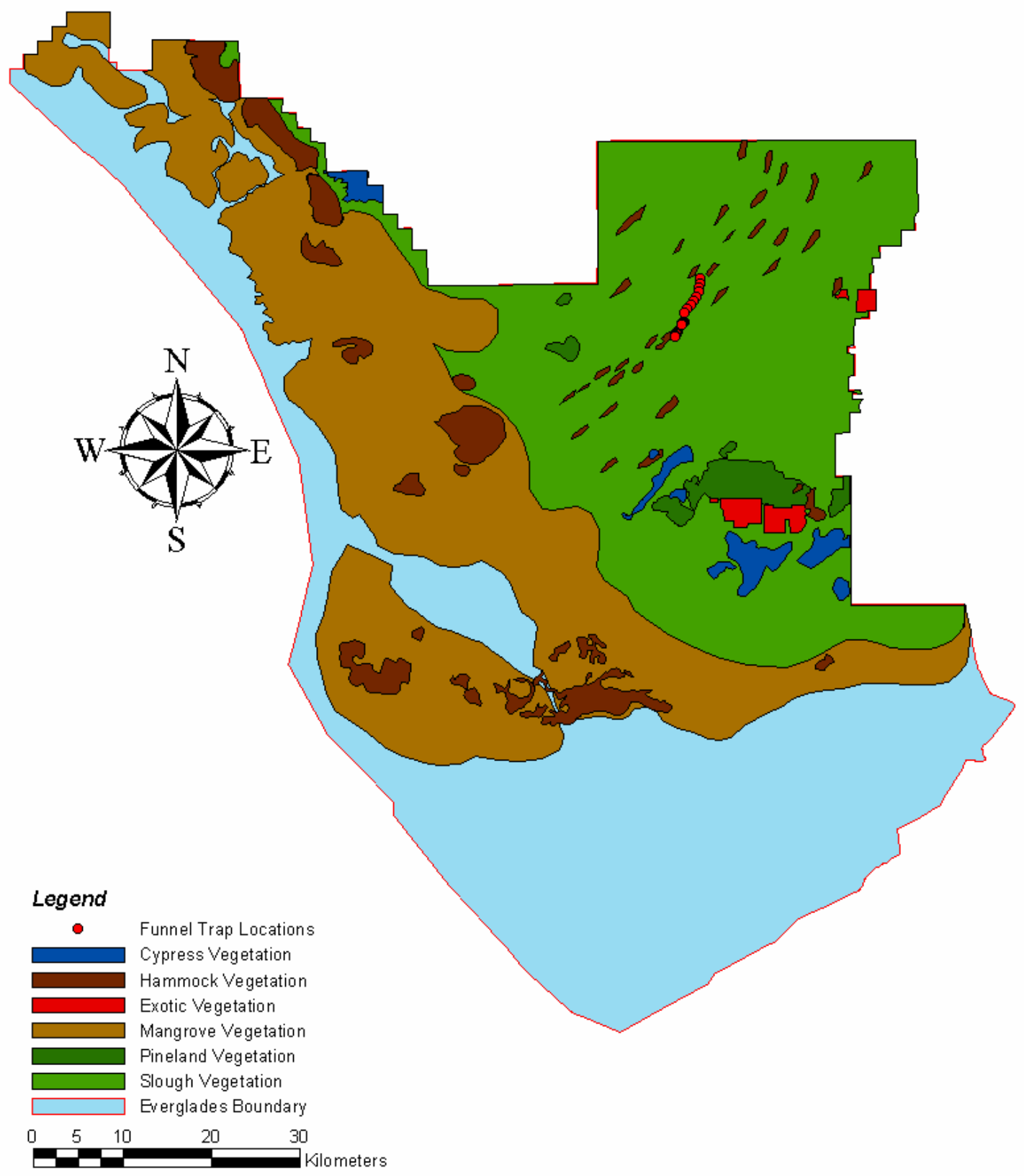

Figure 4: Locations of funnel trapping

Map of all locations at which funnel trap surveys were conducted at Everglades National Park. 
Amphibians of Everglades National Park

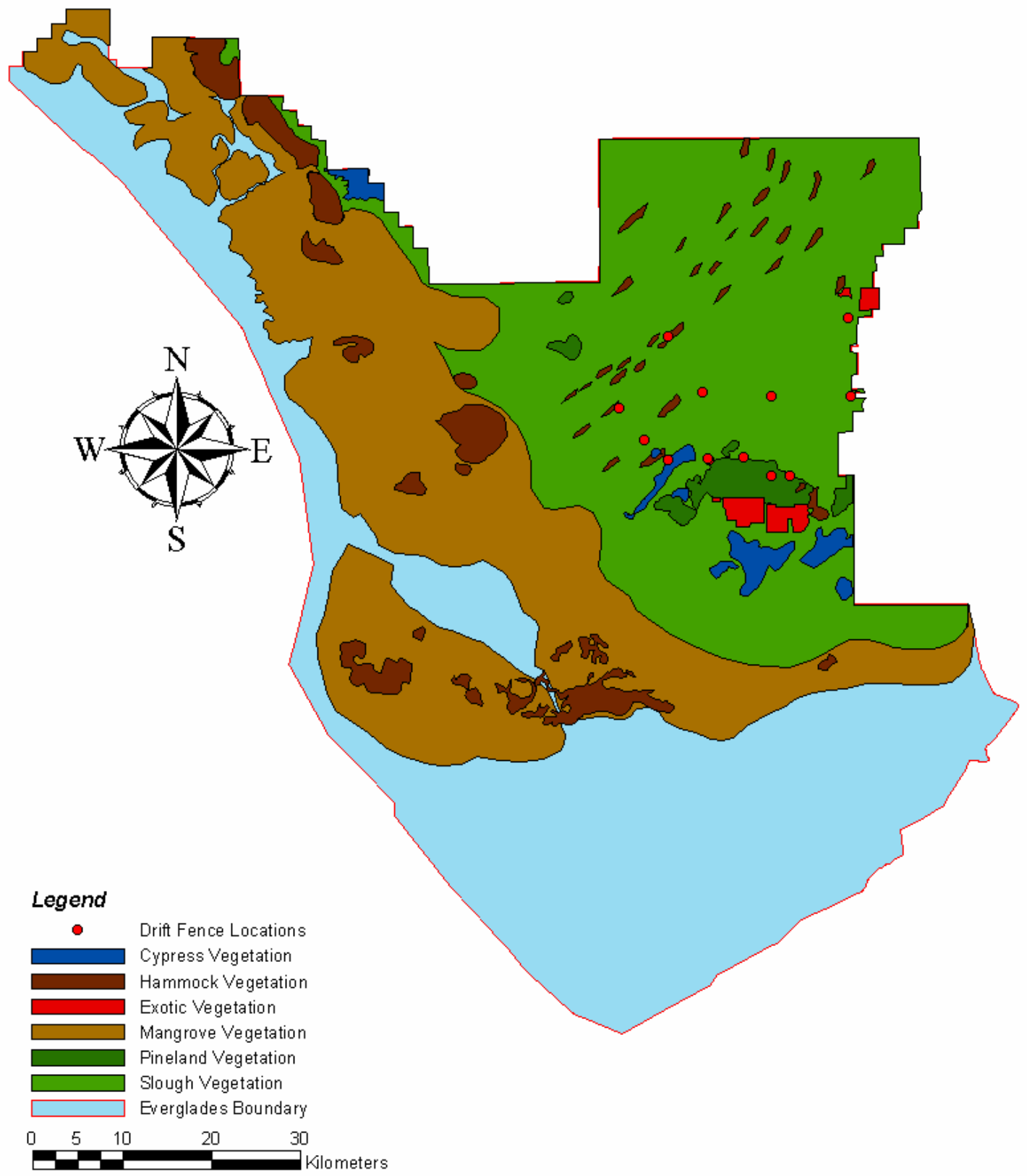

Figure 5: Locations of drift fences

Map of all locations at which Drift Fence surveys were conducted at Everglades National Park. 
Amphibians of Everglades National Park

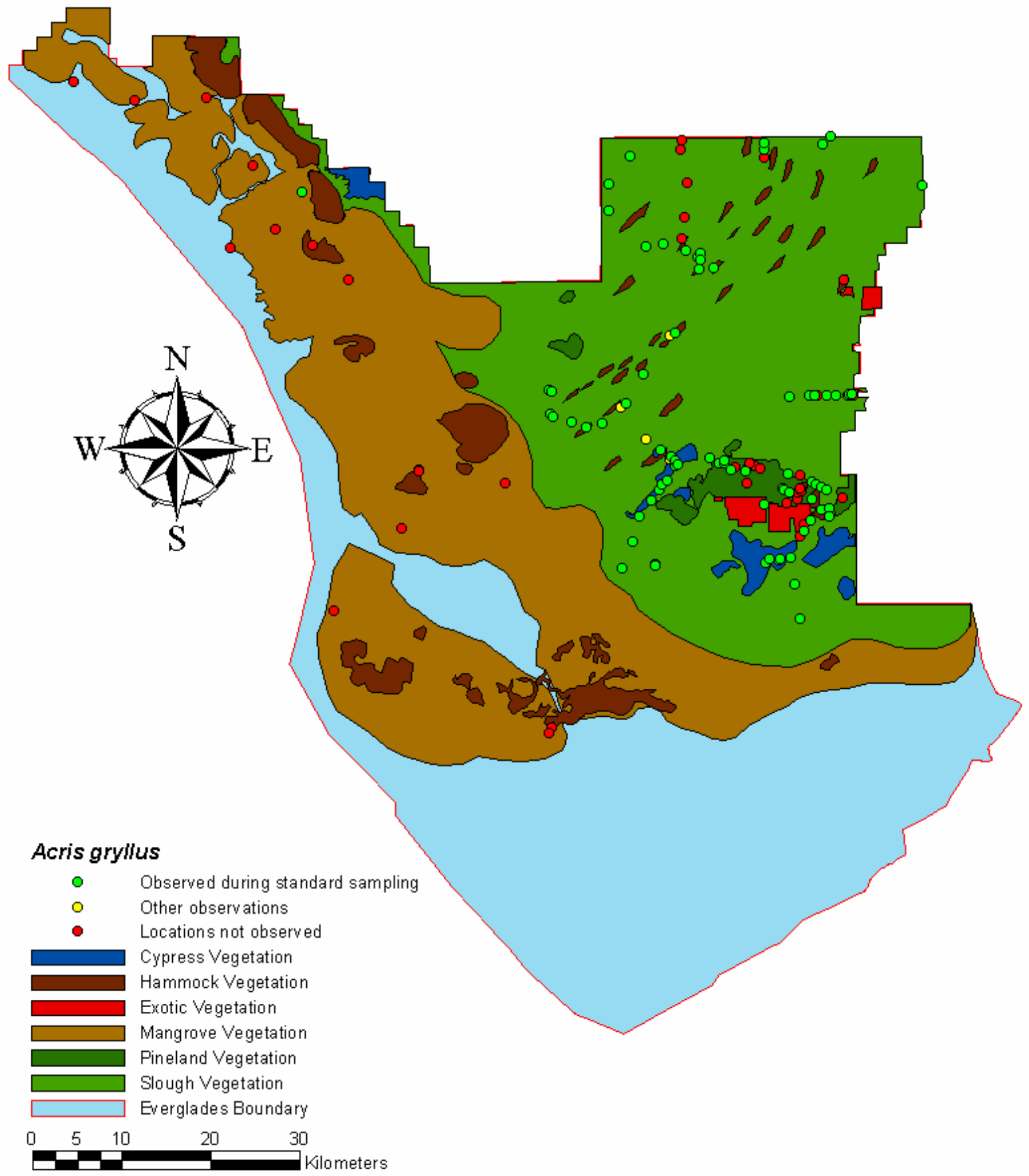

Figure 6: Acris gryllus locations

Map of all locations at which Acris gryllus were observed in Everglades National Park. 
Amphibians of Everglades National Park

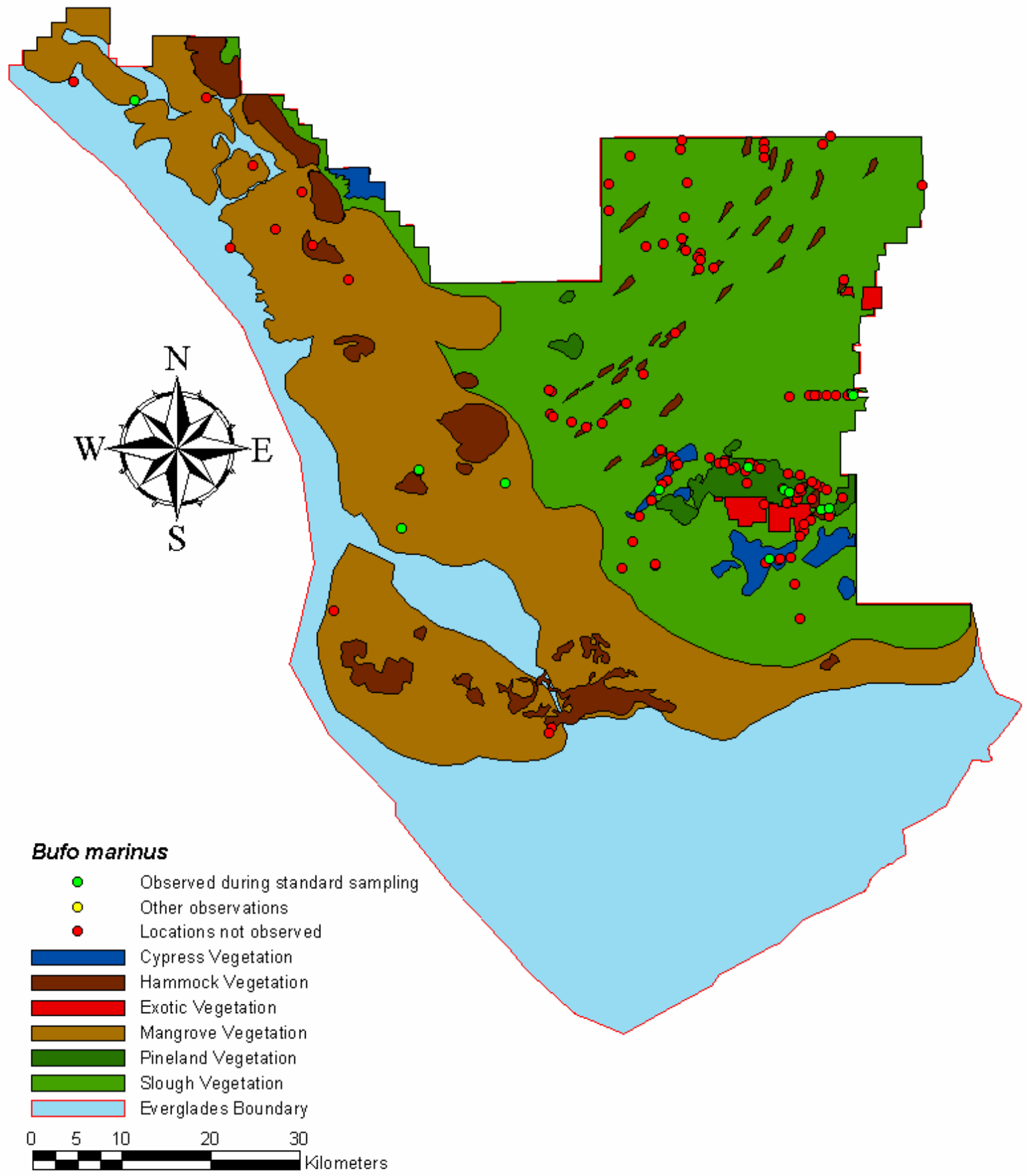

Figure 7: Bufo marinus locations

Map of all locations at which Bufo marinus were observed in Everglades National Park. 
Amphibians of Everglades National Park

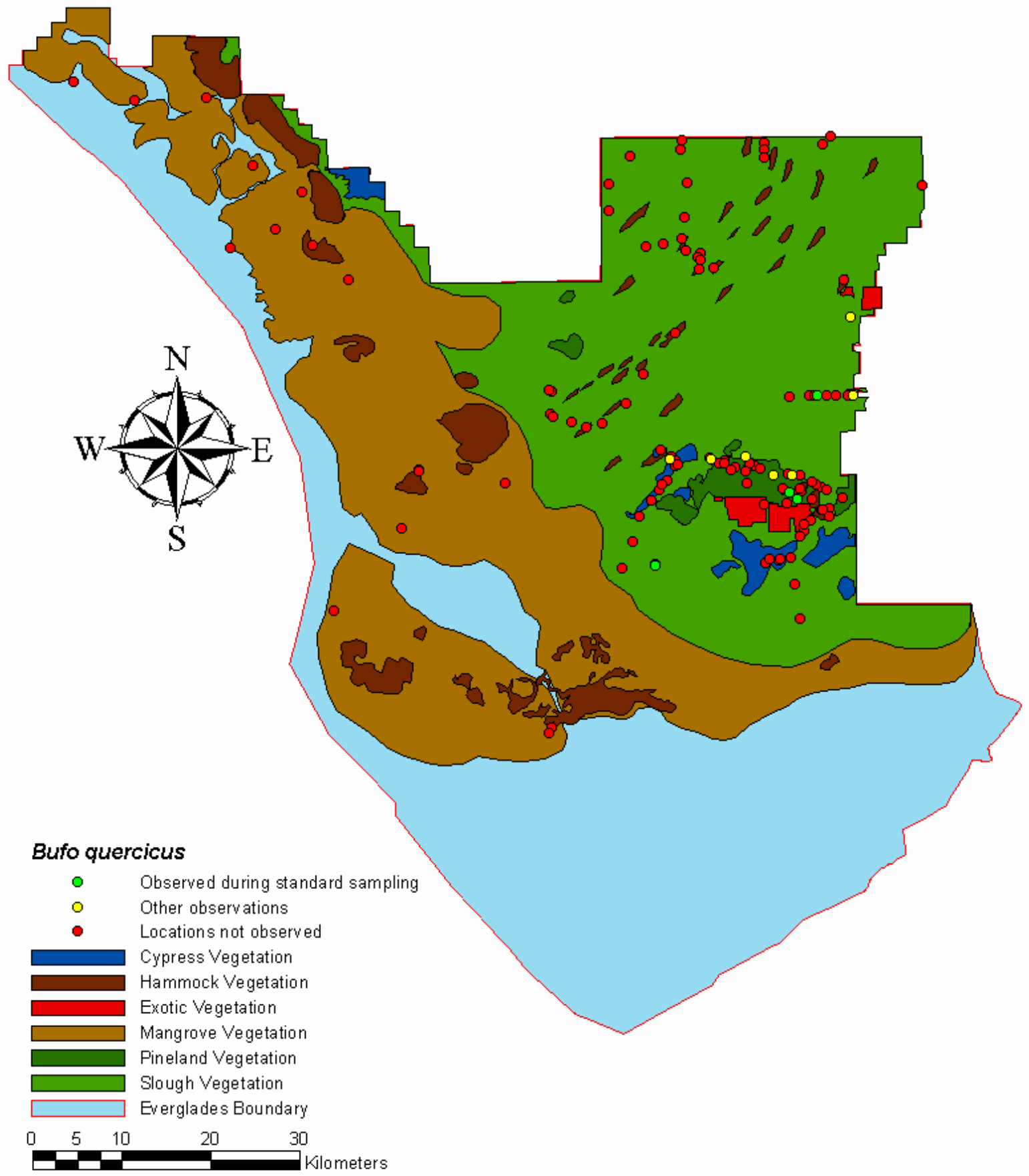

Figure 8: Bufo quercicus locations

Map of all locations at which Bufo quercicus were observed in Everglades National Park. 
Amphibians of Everglades National Park

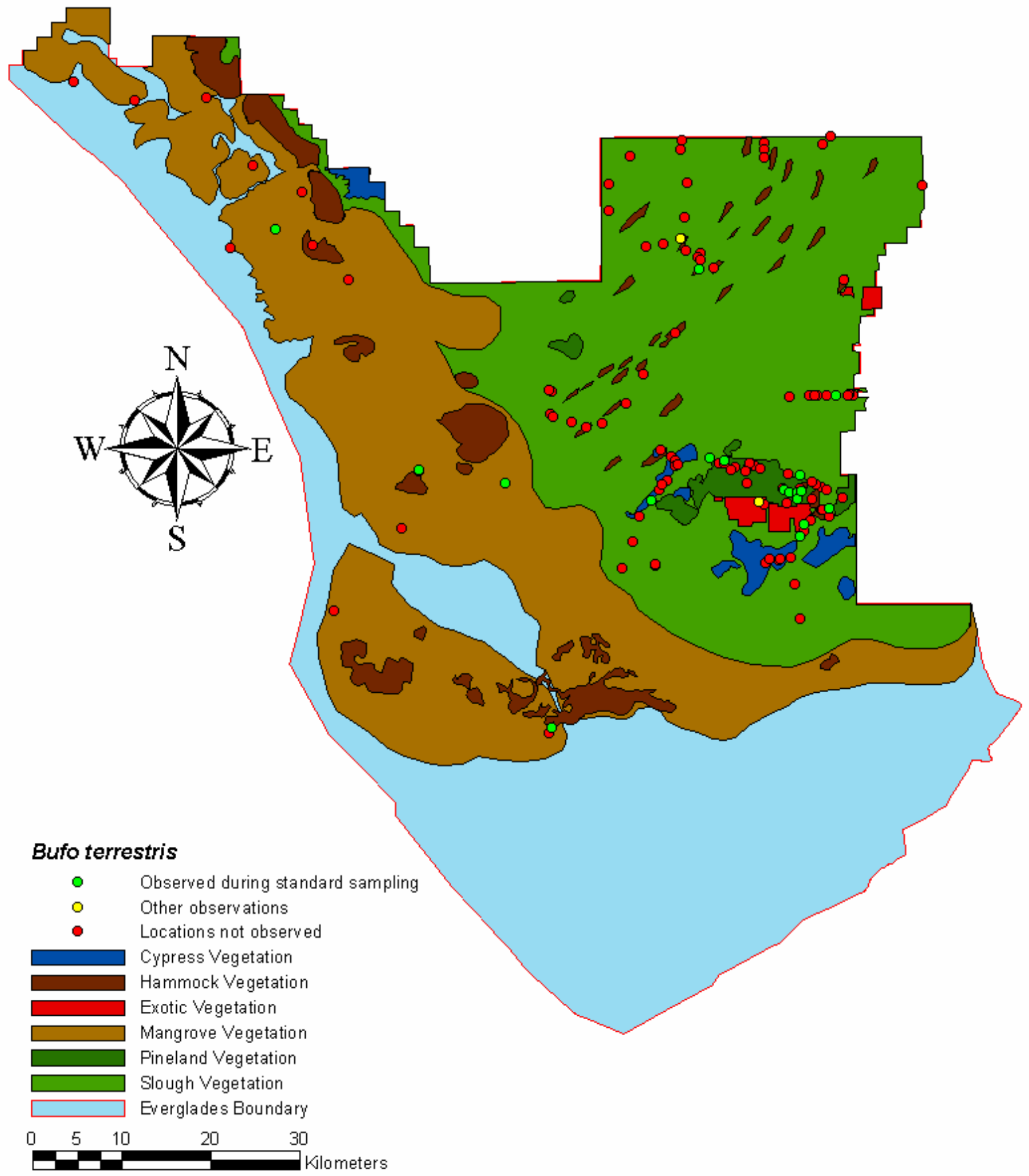

Figure 9: Bufo terrestris locations

Map of all locations at which Bufo terrestris were observed in Everglades National Park. 
Amphibians of Everglades National Park

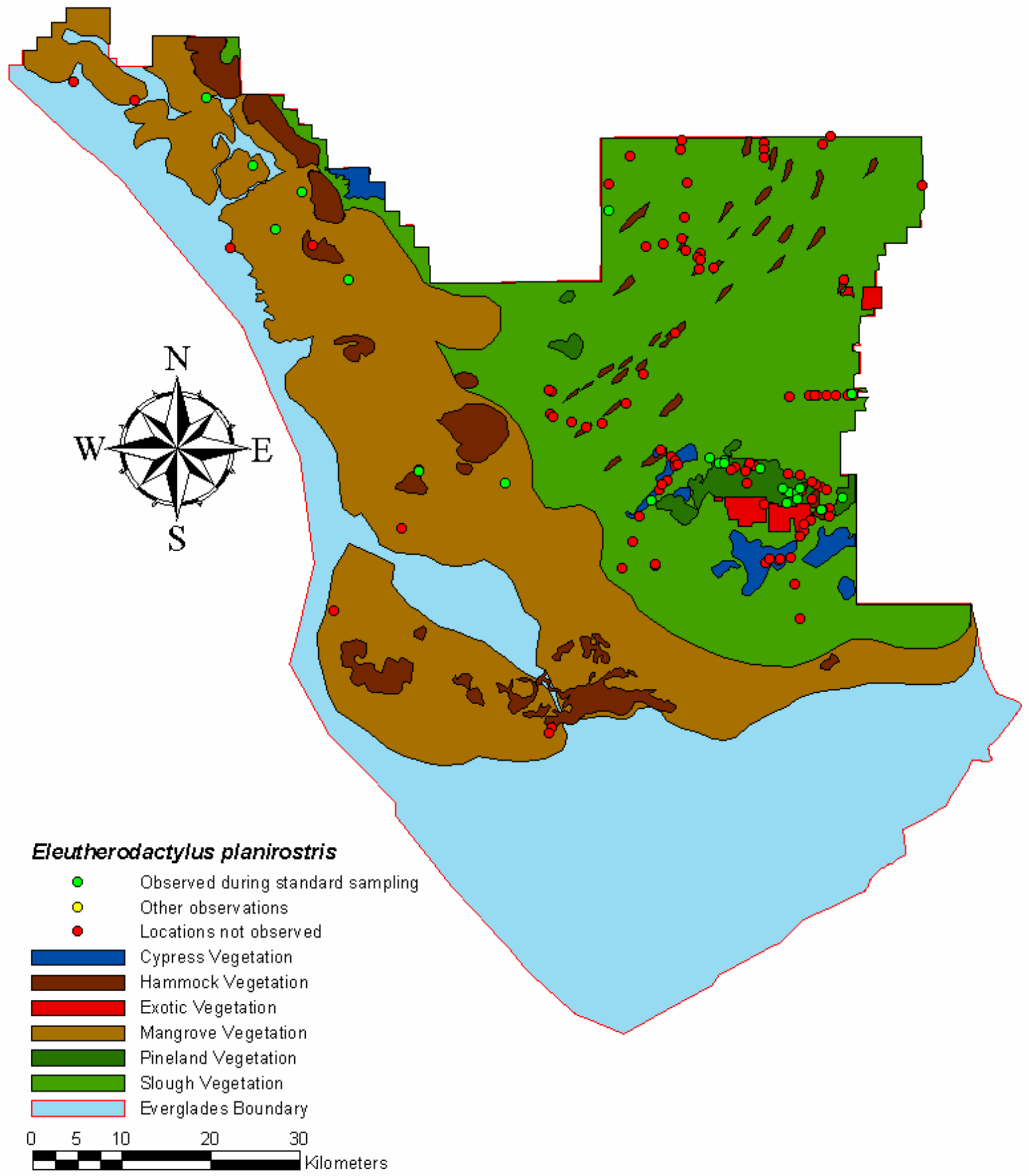

Figure 10: Eleutherodactylus planirostris locations

Map of all locations at which Eleutherodactylus planirostris were observed in Everglades National Park. 
Amphibians of Everglades National Park

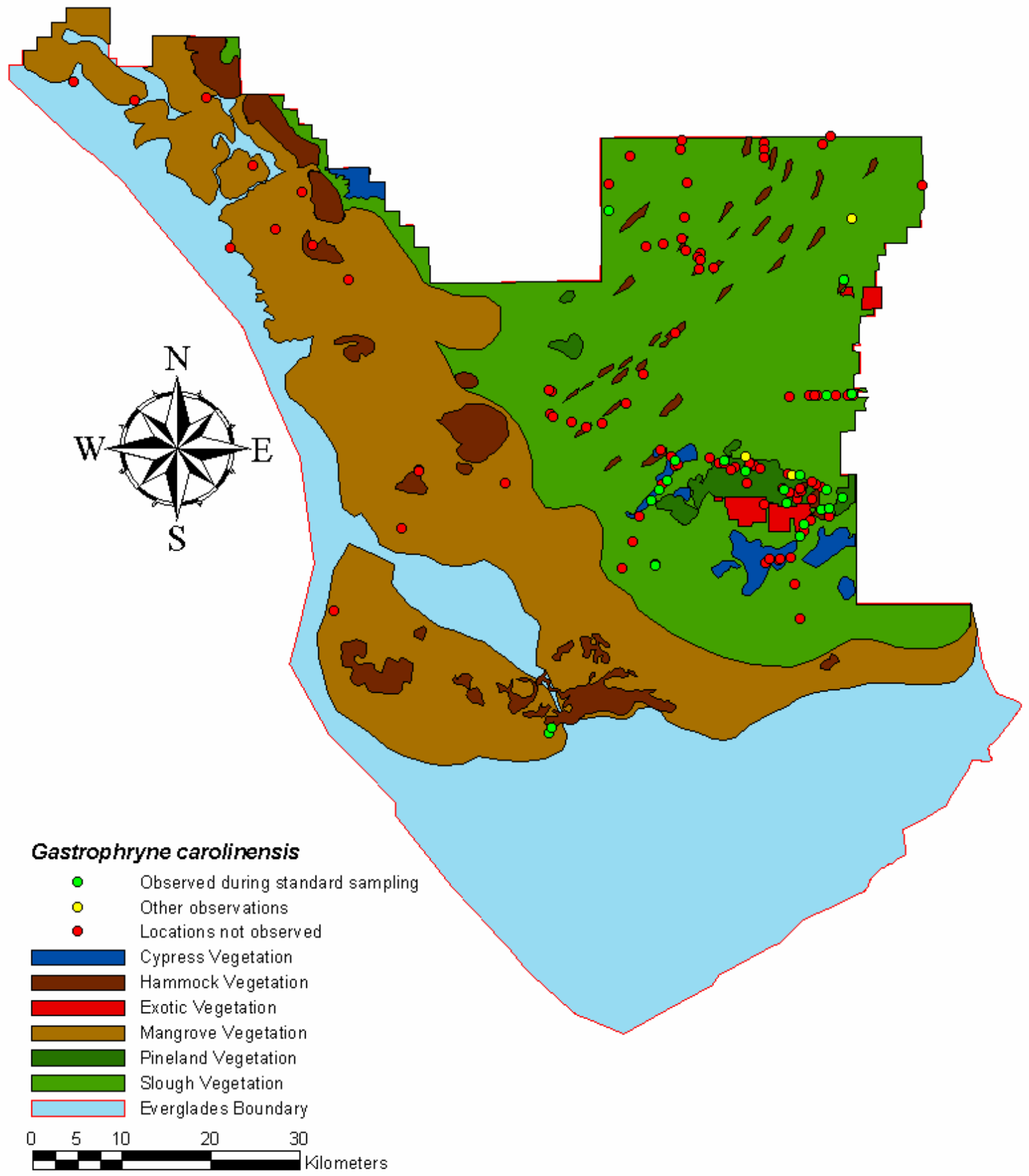

Figure 11: Gastrophryne carolinensis locations

Map of all locations at which Gastrophryne carolinensis were observed in Everglades National Park. 
Amphibians of Everglades National Park

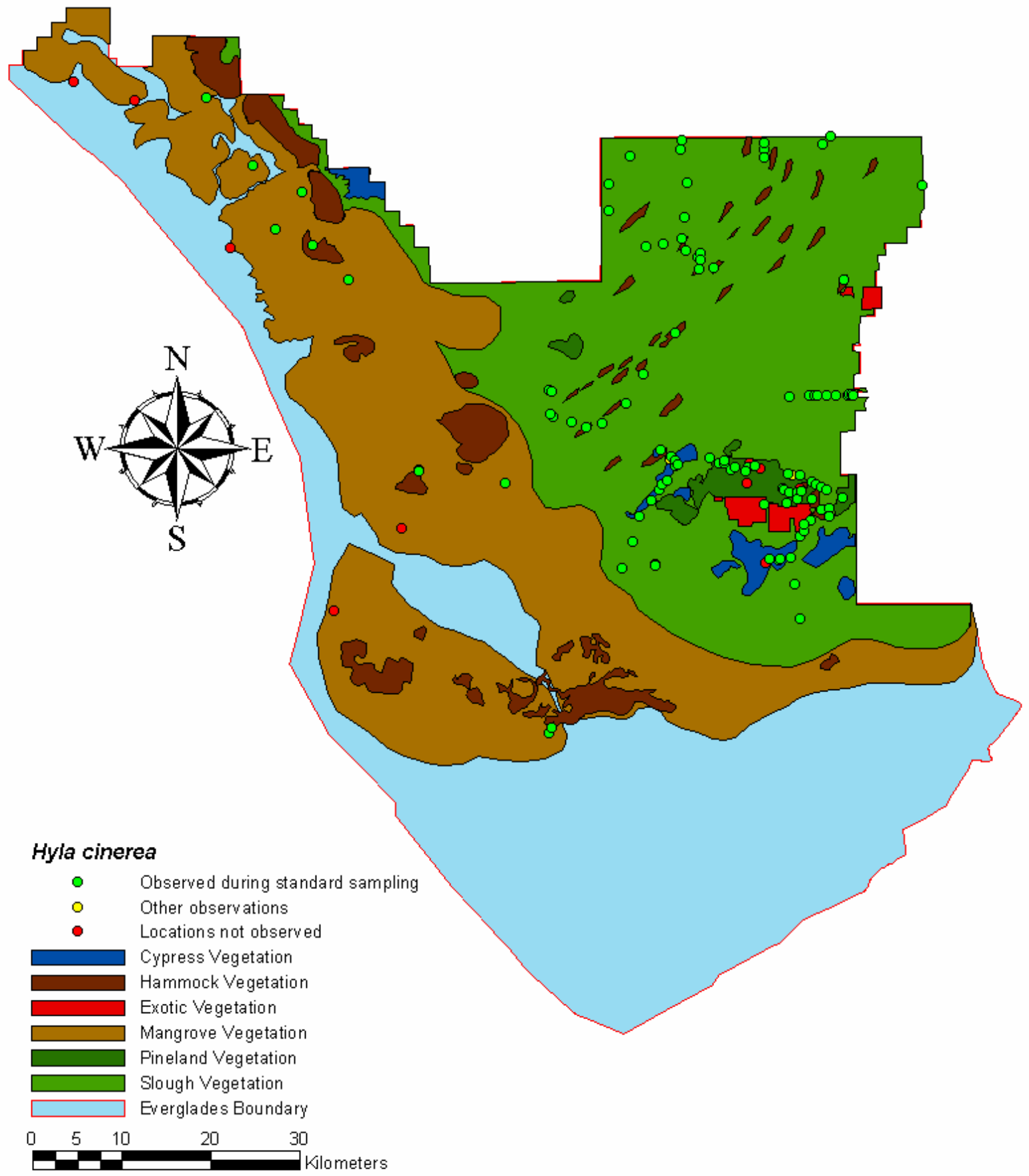

Figure 12: Hyla cinerea locations

Map of all locations at which Hyla cinerea were observed in Everglades National Park. 
Amphibians of Everglades National Park

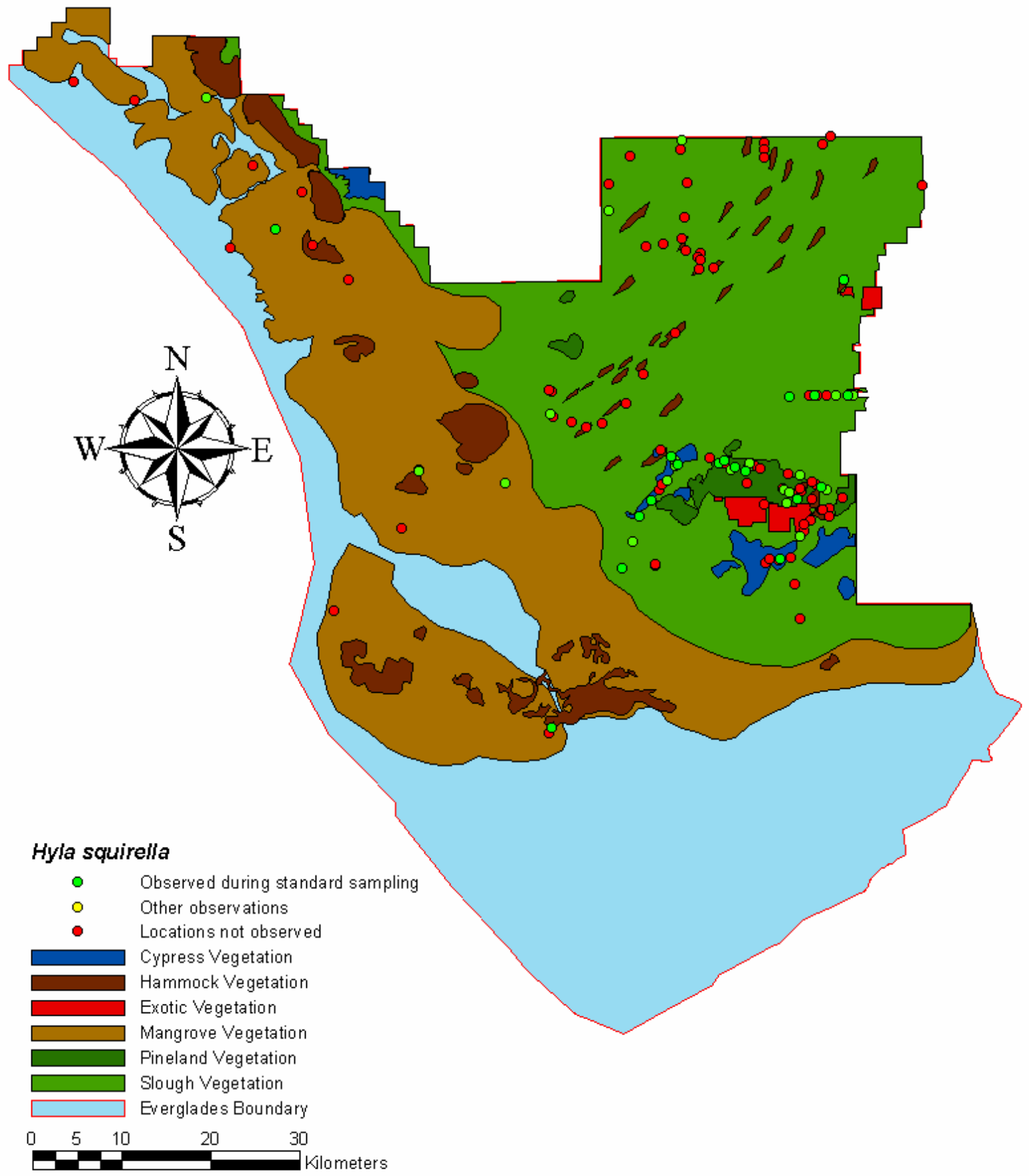

Figure 13: Hyla squirella locations

Map of all locations at which Hyla squirella were observed in Everglades National Park. 
Amphibians of Everglades National Park

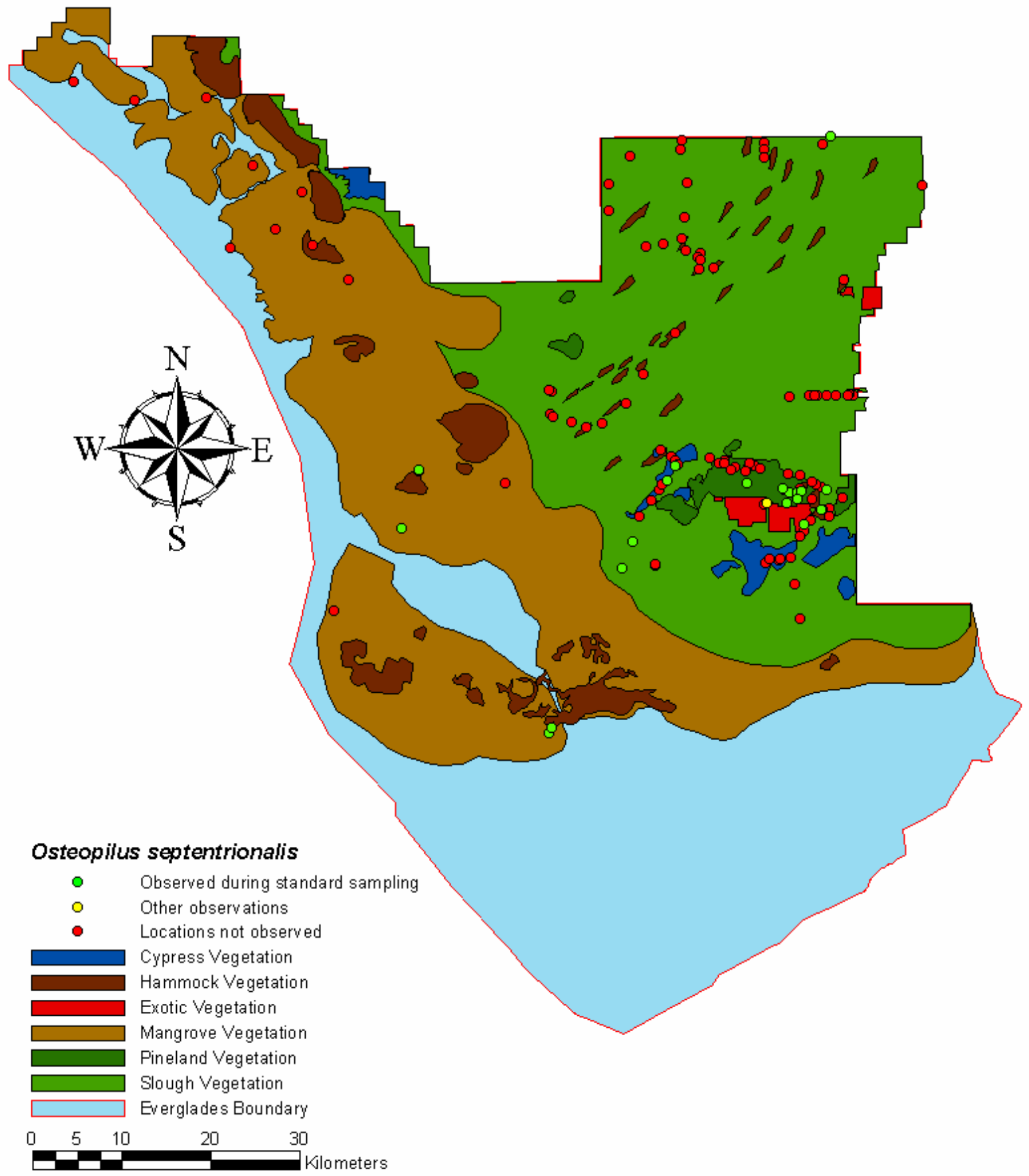

Figure 14: Osteopilus septentrionalis locations

Map of all locations at which Osteopilus septentrionalis were observed in Everglades National Park. 
Amphibians of Everglades National Park

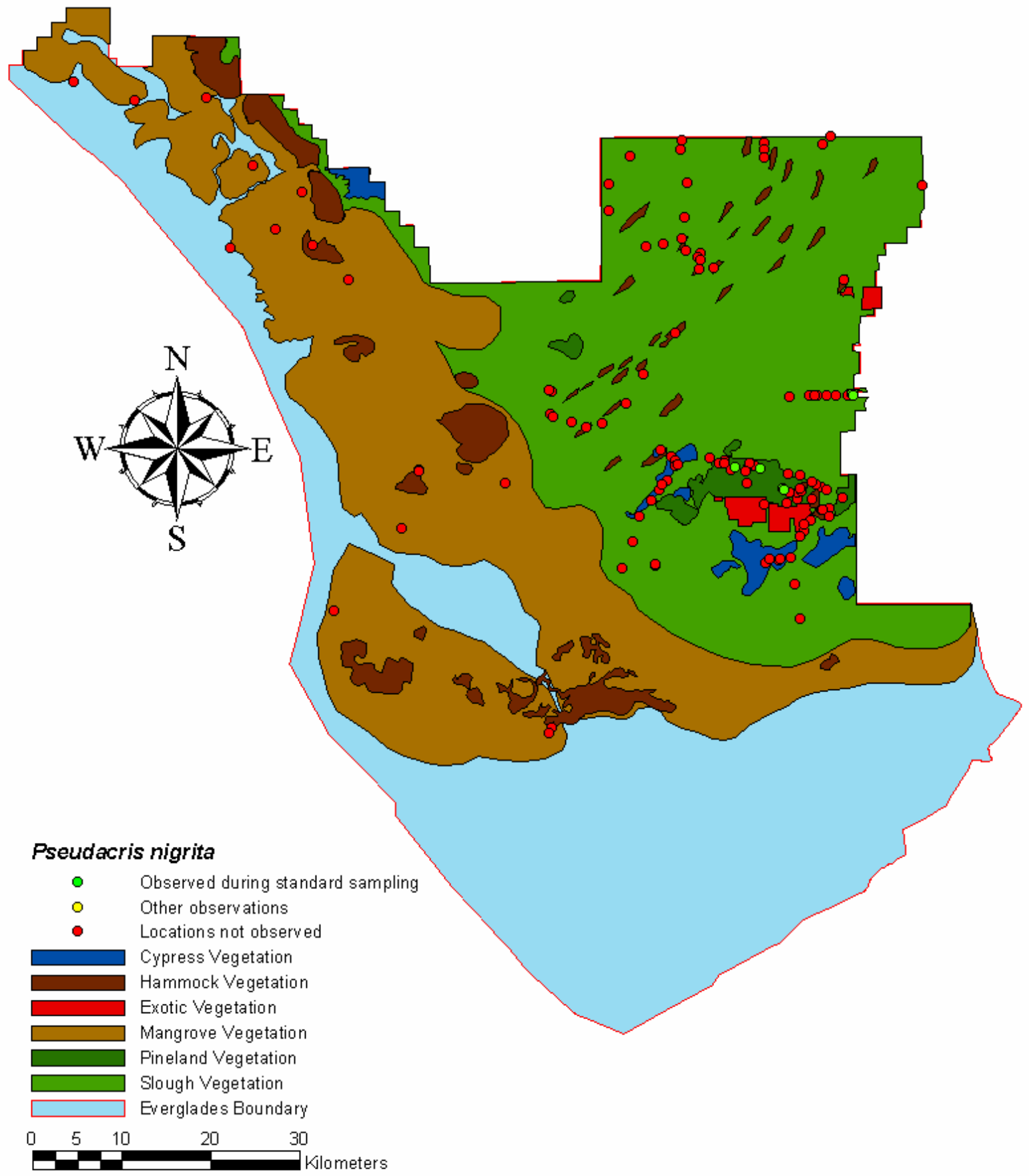

Figure 15: Pseudacris nigrita locations

Map of all locations at which Pseudacris nigrita were observed in Everglades National Park. 
Amphibians of Everglades National Park

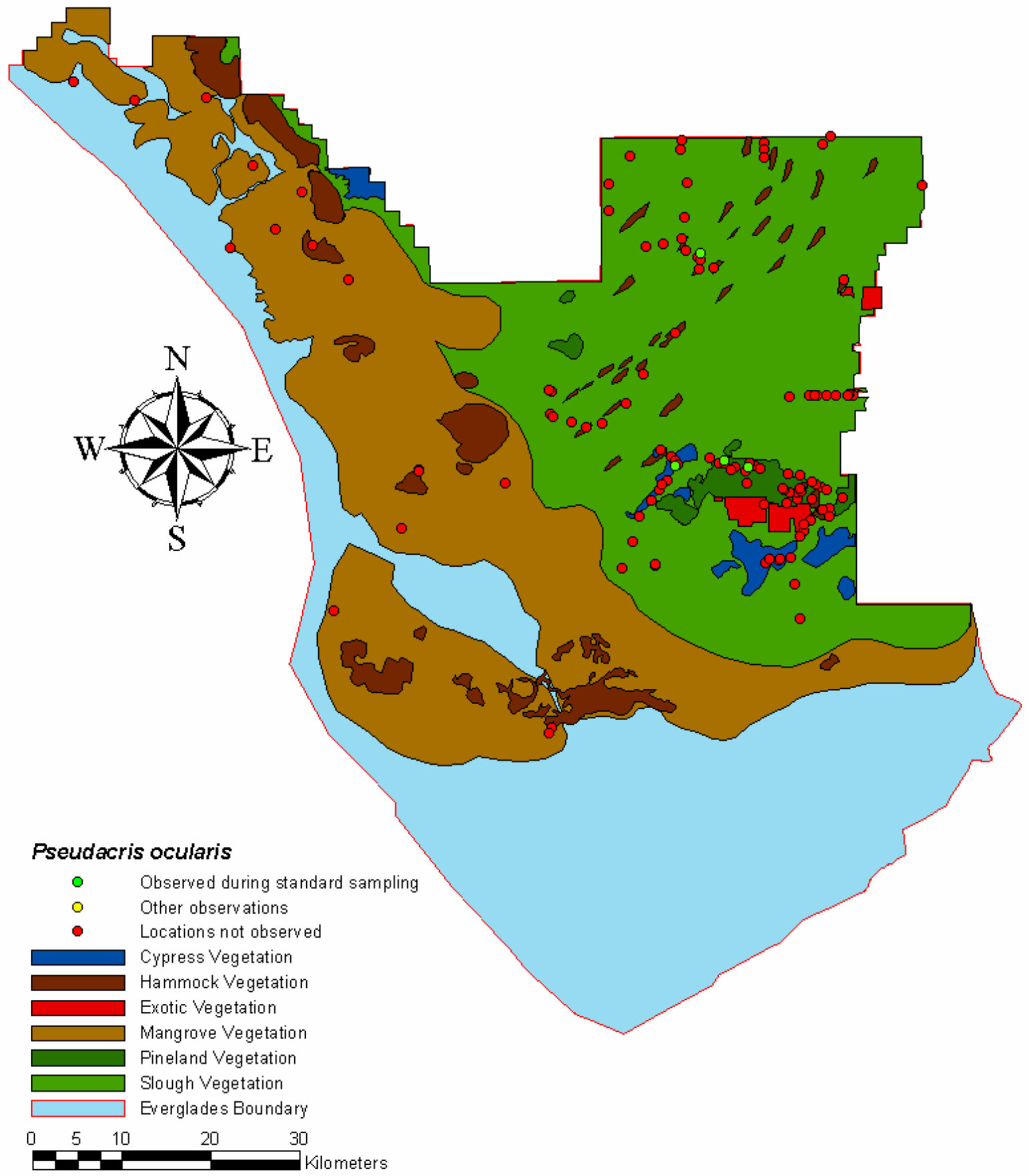

Figure 16: Pseudacris ocularis locations

Map of all locations at which Pseudacris ocularis were observed in Everglades National Park. 
Amphibians of Everglades National Park

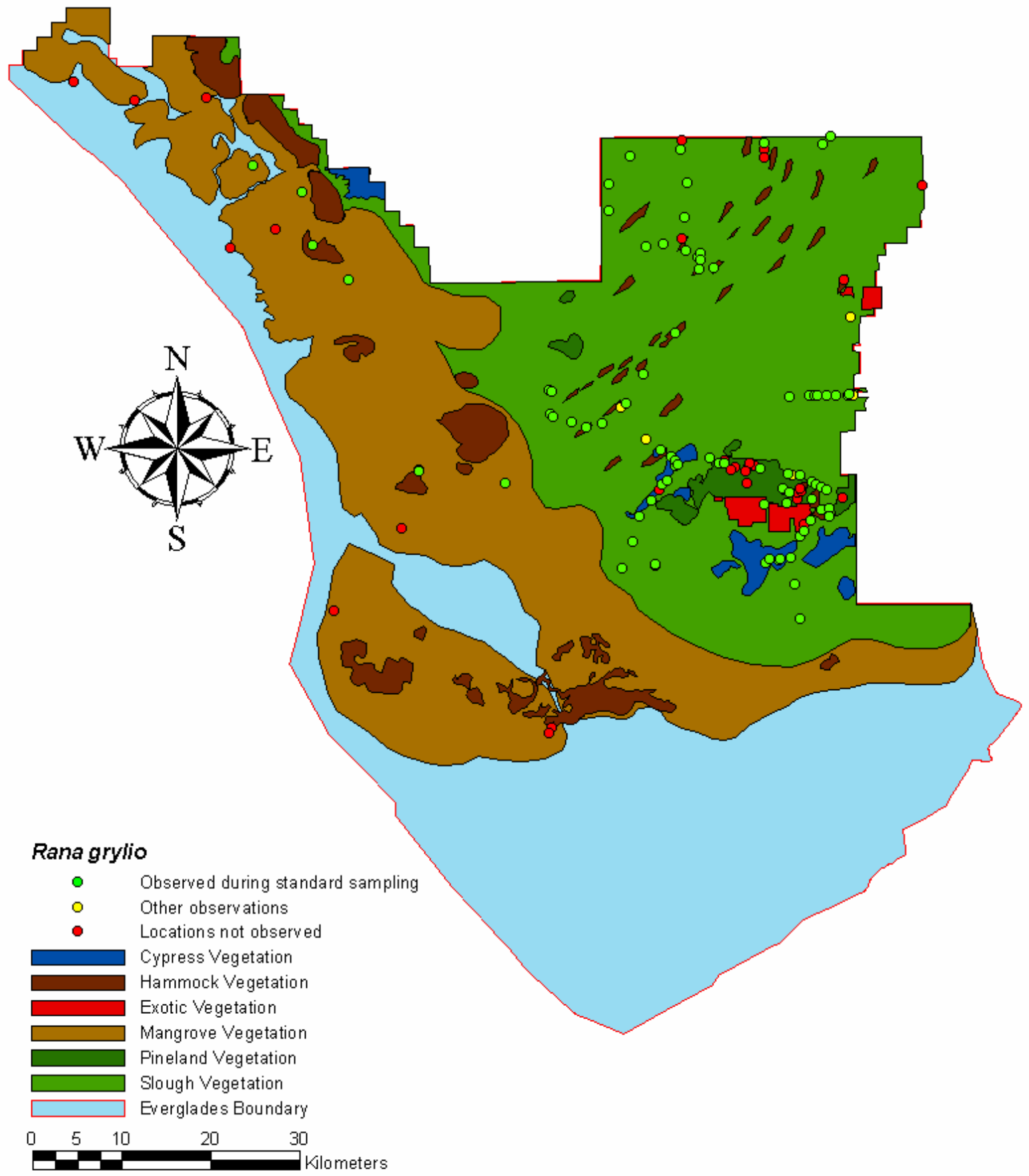

Figure 17: Rana grylio locations

Map of all locations at which Rana grylio were observed in Everglades National Park. 
Amphibians of Everglades National Park

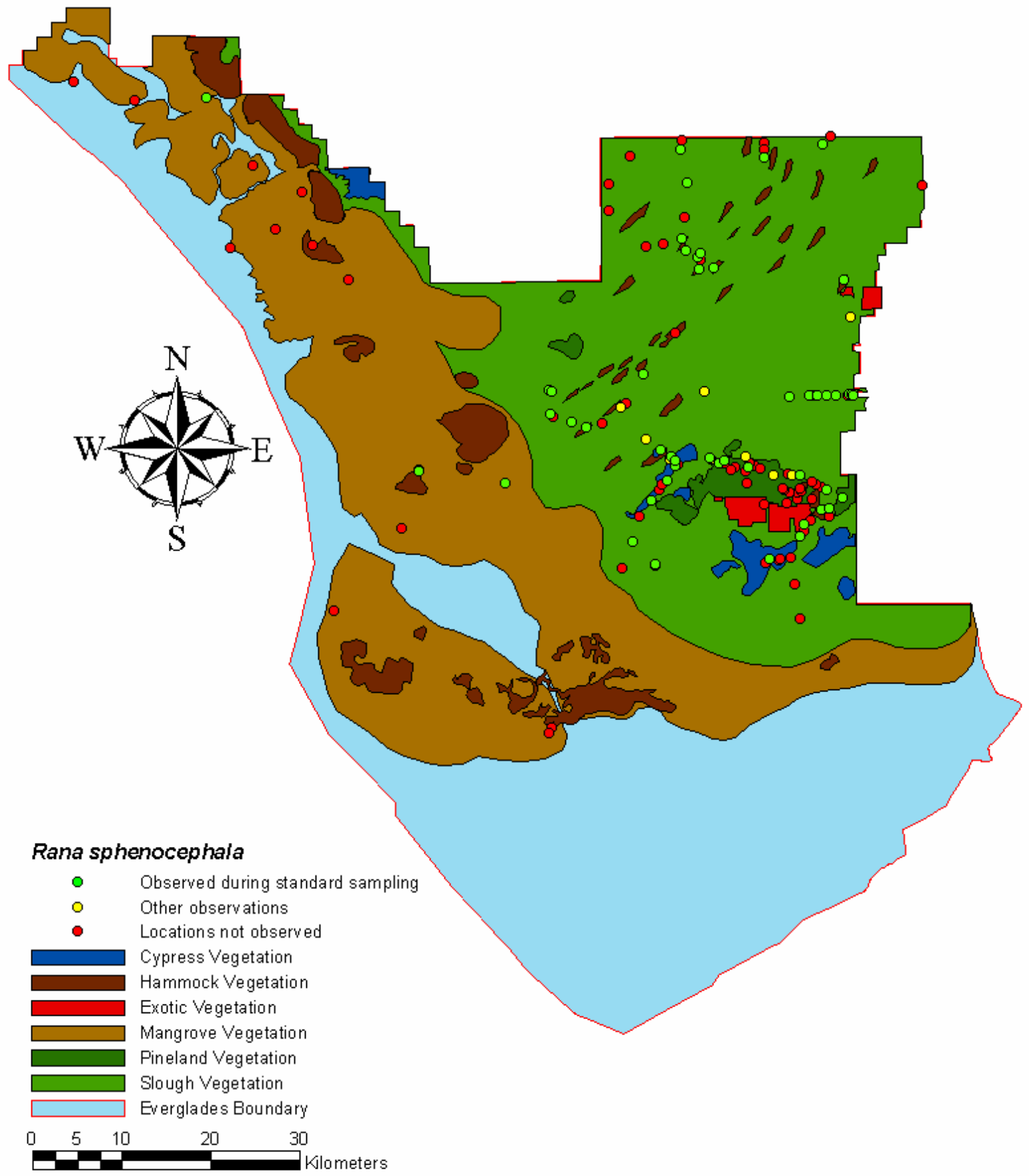

Figure 18: Rana sphenocephala locations

Map of all locations at which Rana sphenocephala were observed in Everglades National Park. 
Amphibians of Everglades National Park

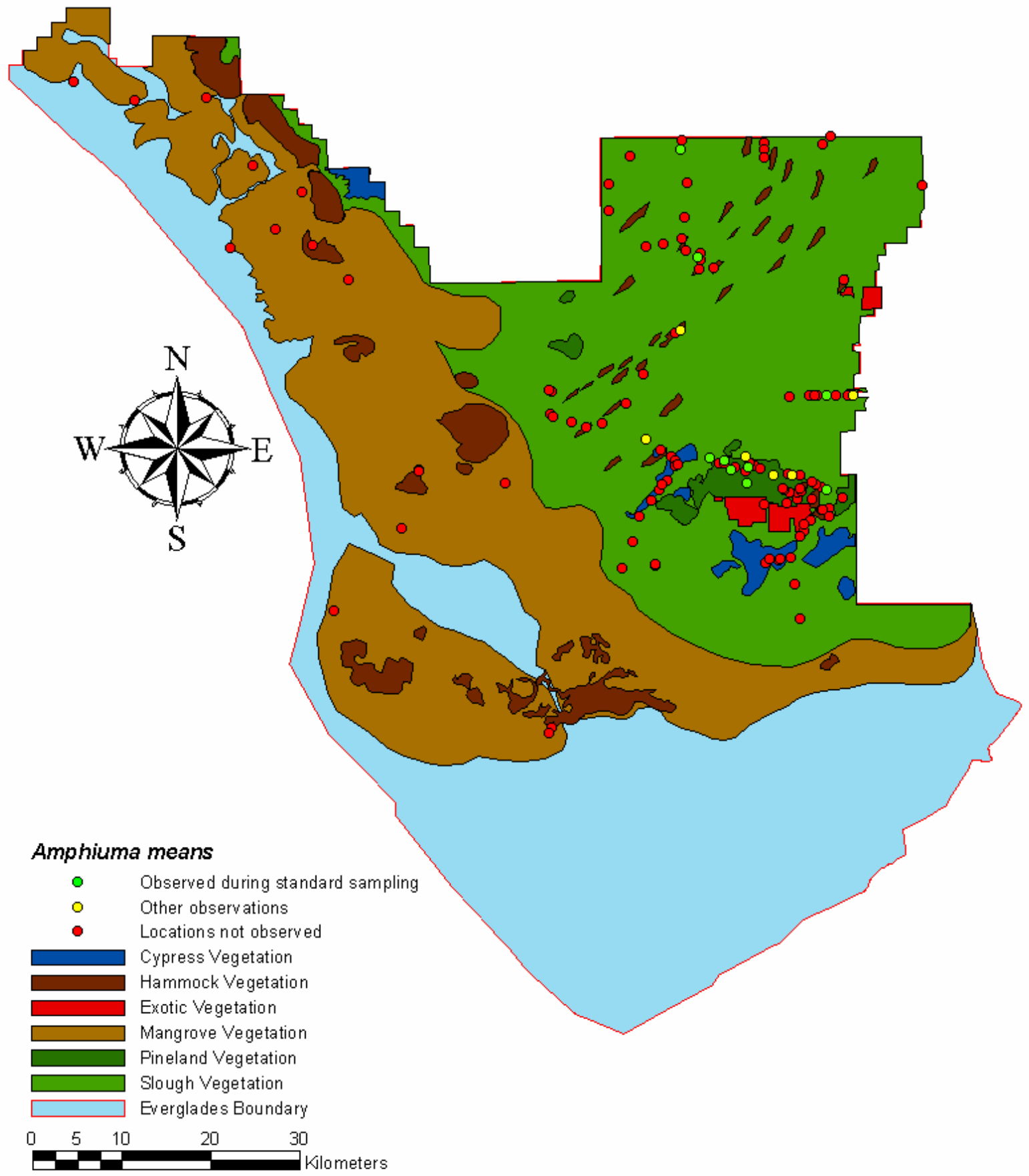

Figure 19: Amphiuma means locations

Map of all locations at which Amphiuma means were observed in Everglades National Park. 
Amphibians of Everglades National Park

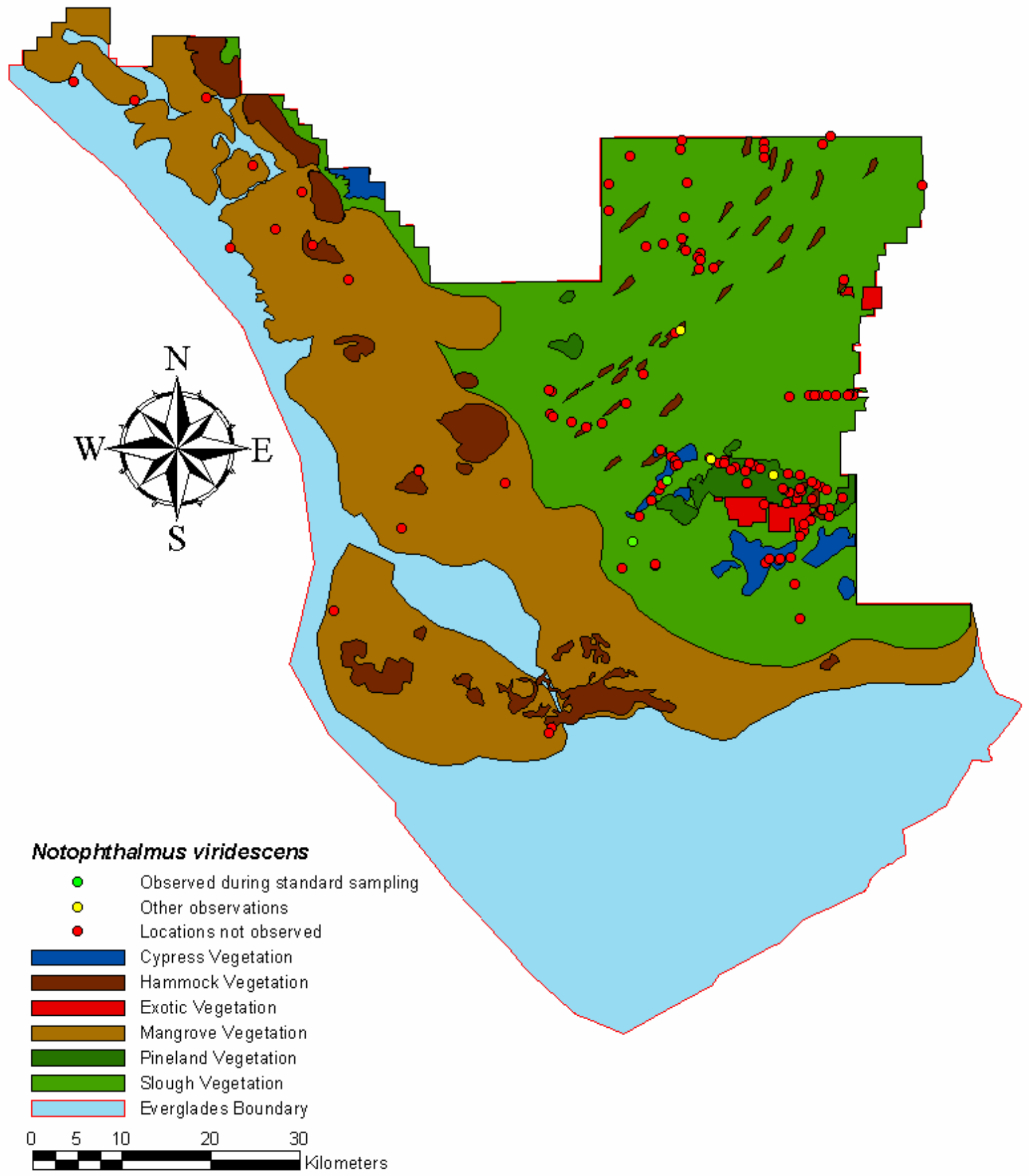

Figure 20: Notophthalmus viridescens locations

Map of all locations at which Notophthalmus viridescens were observed in Everglades National Park. 
Amphibians of Everglades National Park

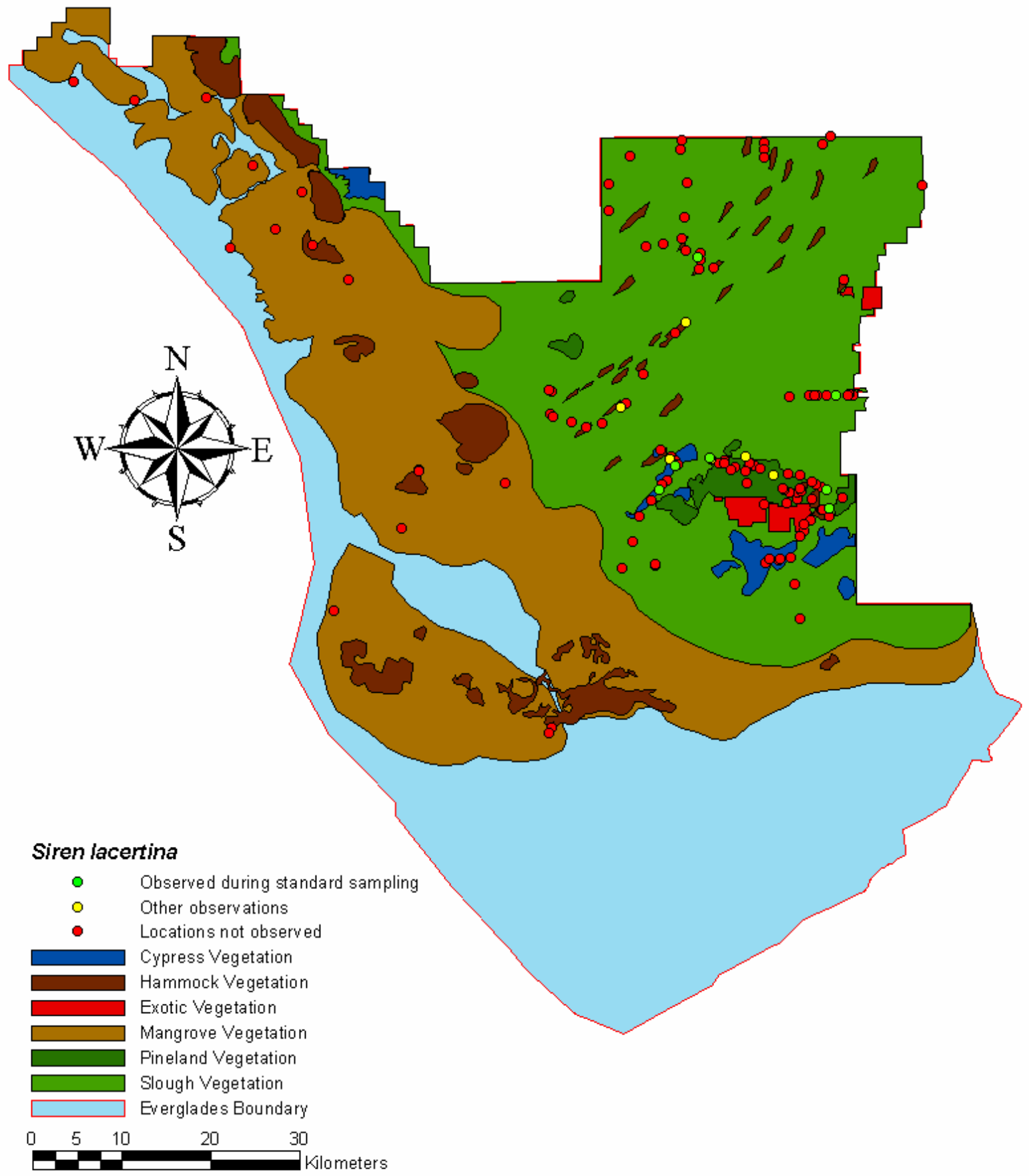

Figure 21: Siren lacertina locations

Map of all locations at which Siren lacertina were observed in Everglades National Park. 
Amphibians of Everglades National Park

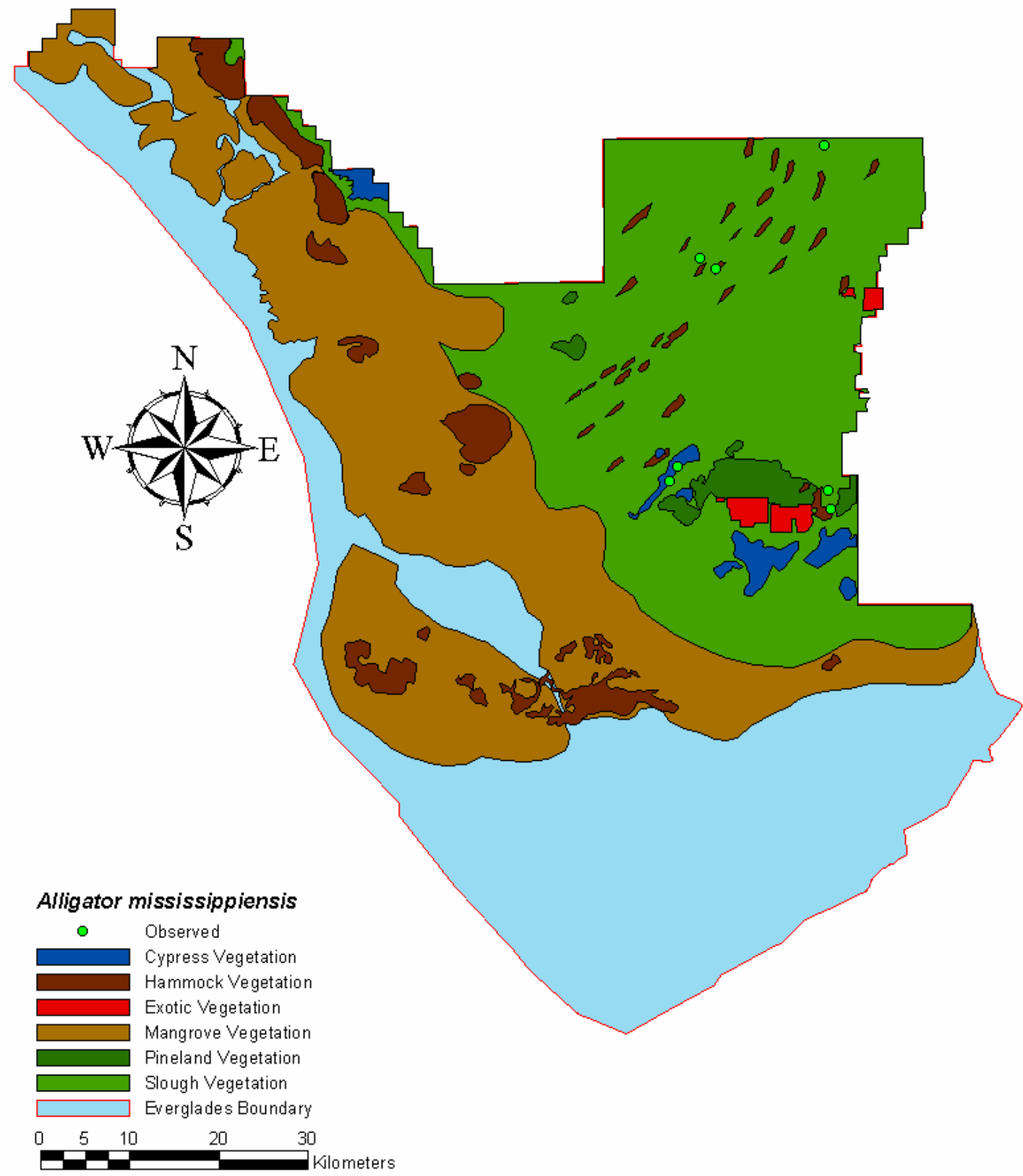

Figure 22: Alligator mississippiensis locations

Map of all locations at which Alligator mississippiensis were observed in Everglades National Park. 
Amphibians of Everglades National Park

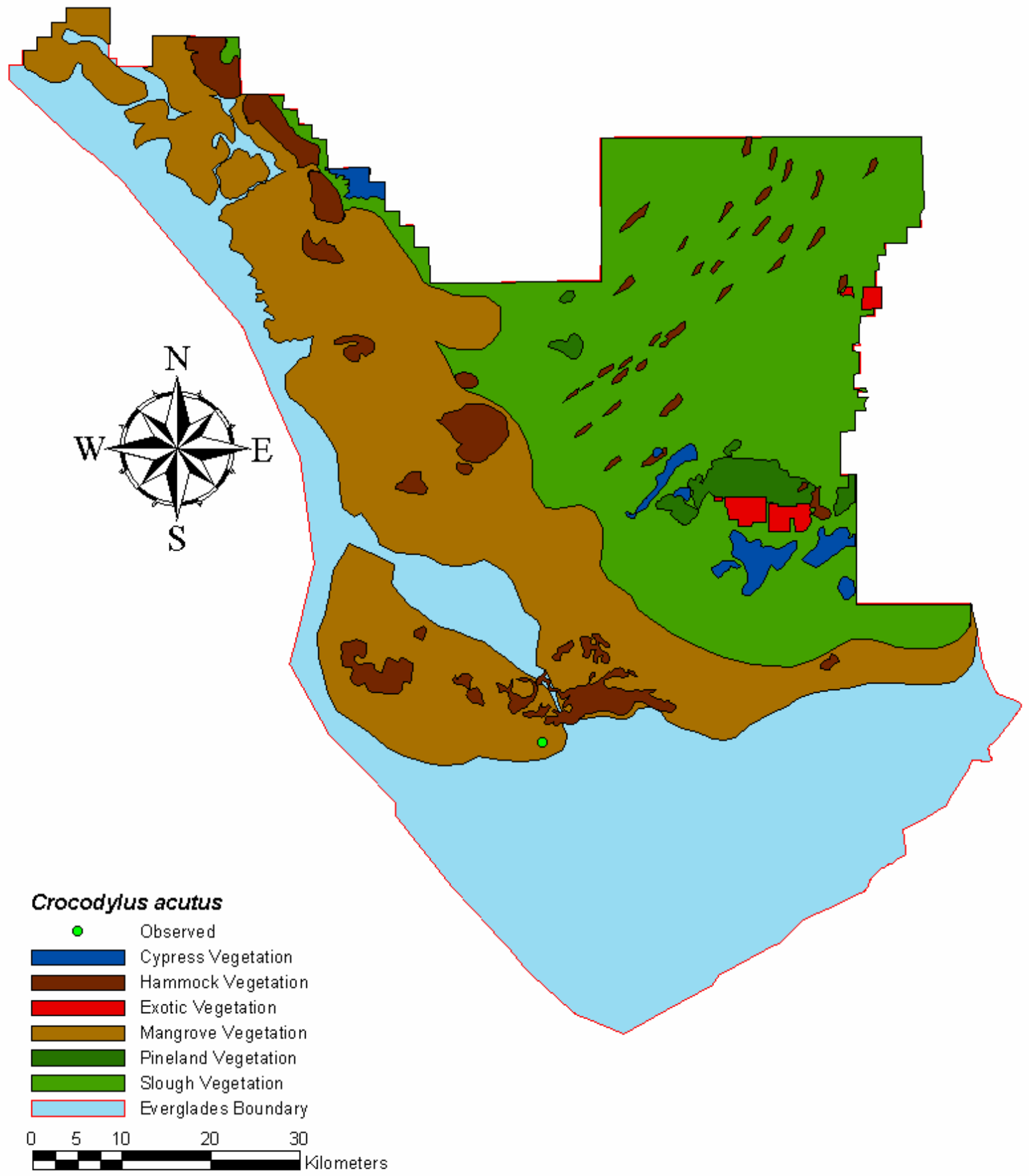

Figure 23: Crocodylus acutus locations

Map of all locations at which Crocodylus acutus were observed in Everglades National Park. 
Amphibians of Everglades National Park

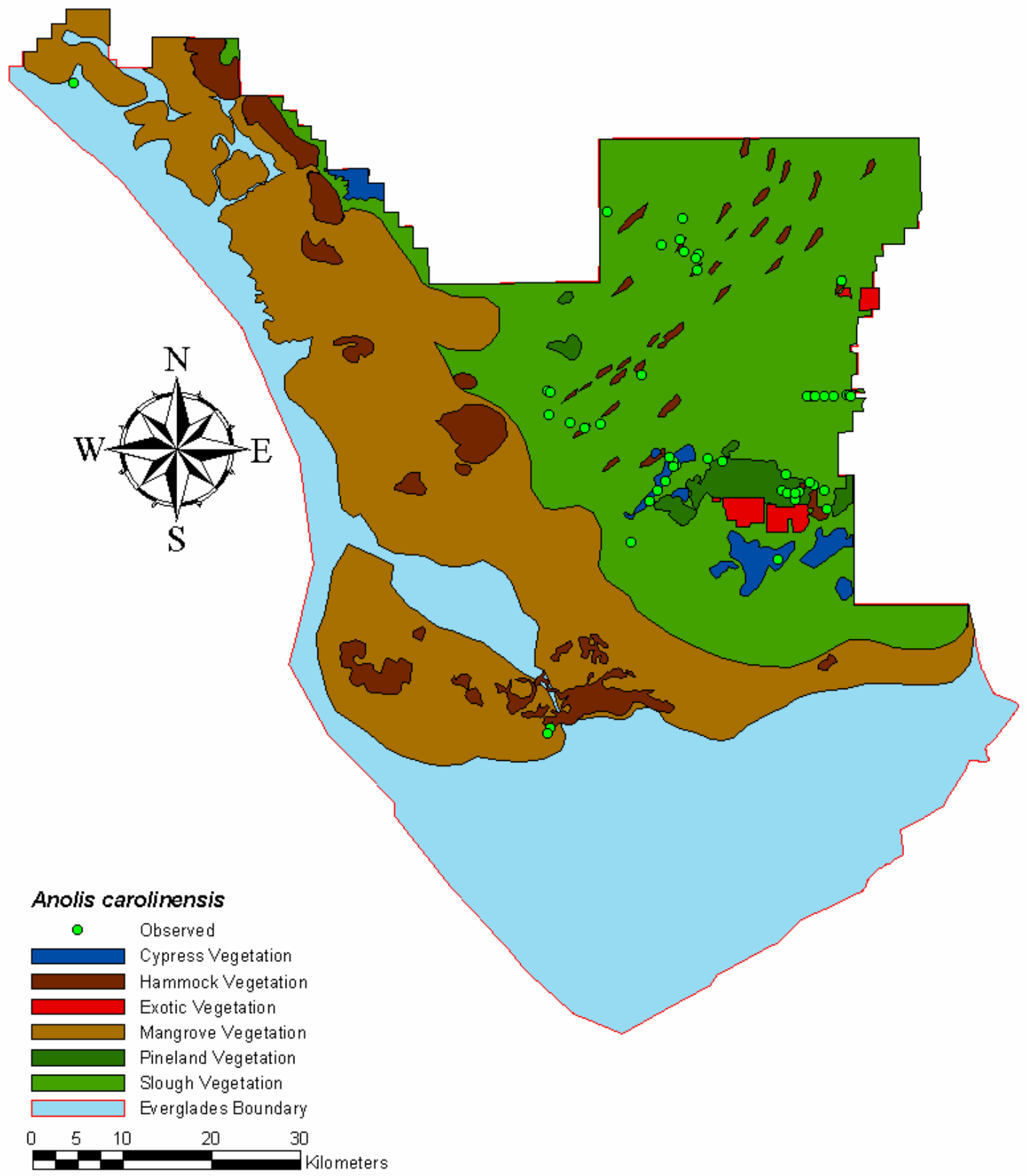

Figure 24: Anolis carolinensis locations

Map of all locations at which Anolis carolinensis were observed in Everglades National Park. 
Amphibians of Everglades National Park

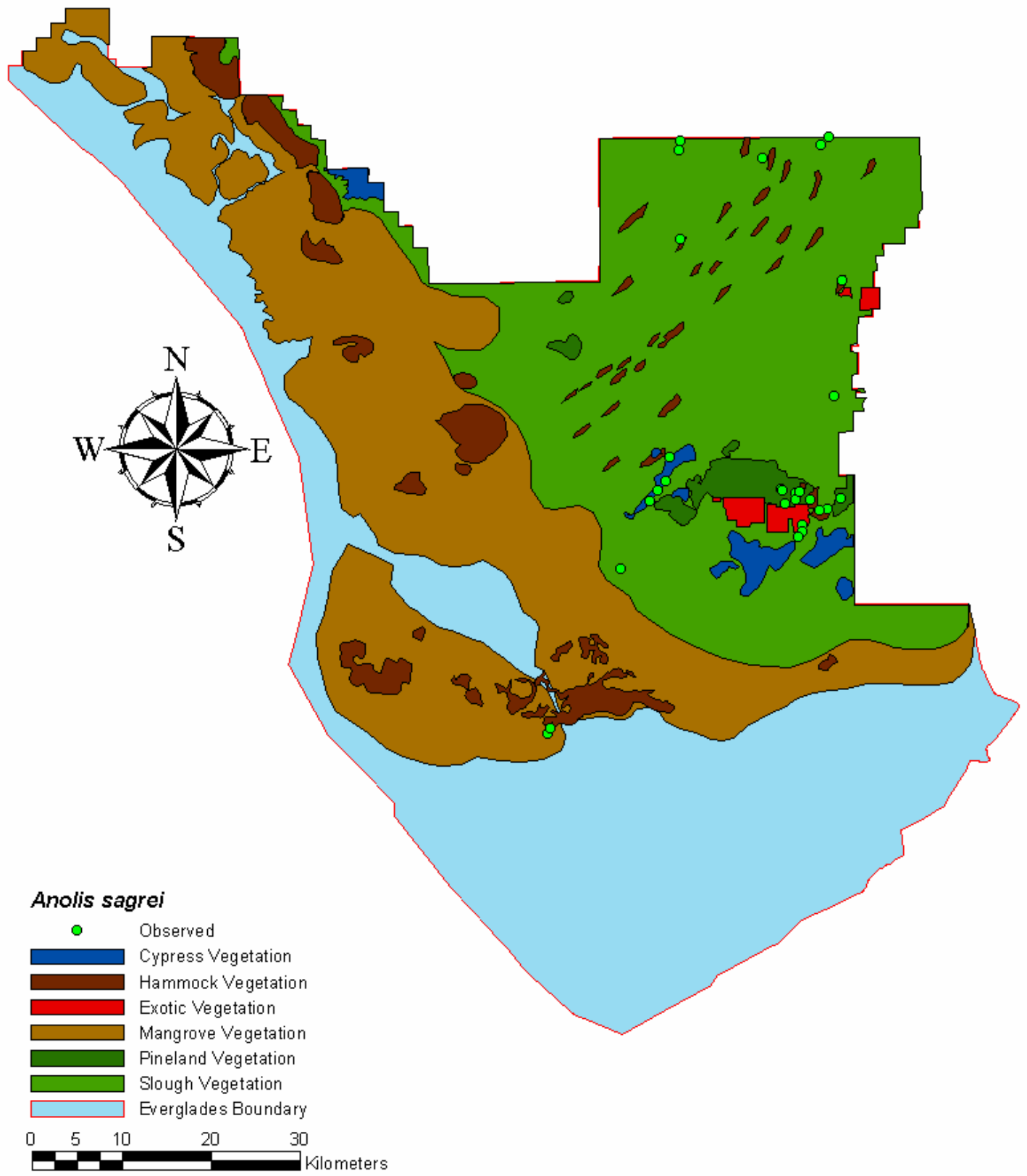

Figure 25: Anolis sagrei locations

Map of all locations at which Anolis sagrei were observed in Everglades National Park. 
Amphibians of Everglades National Park

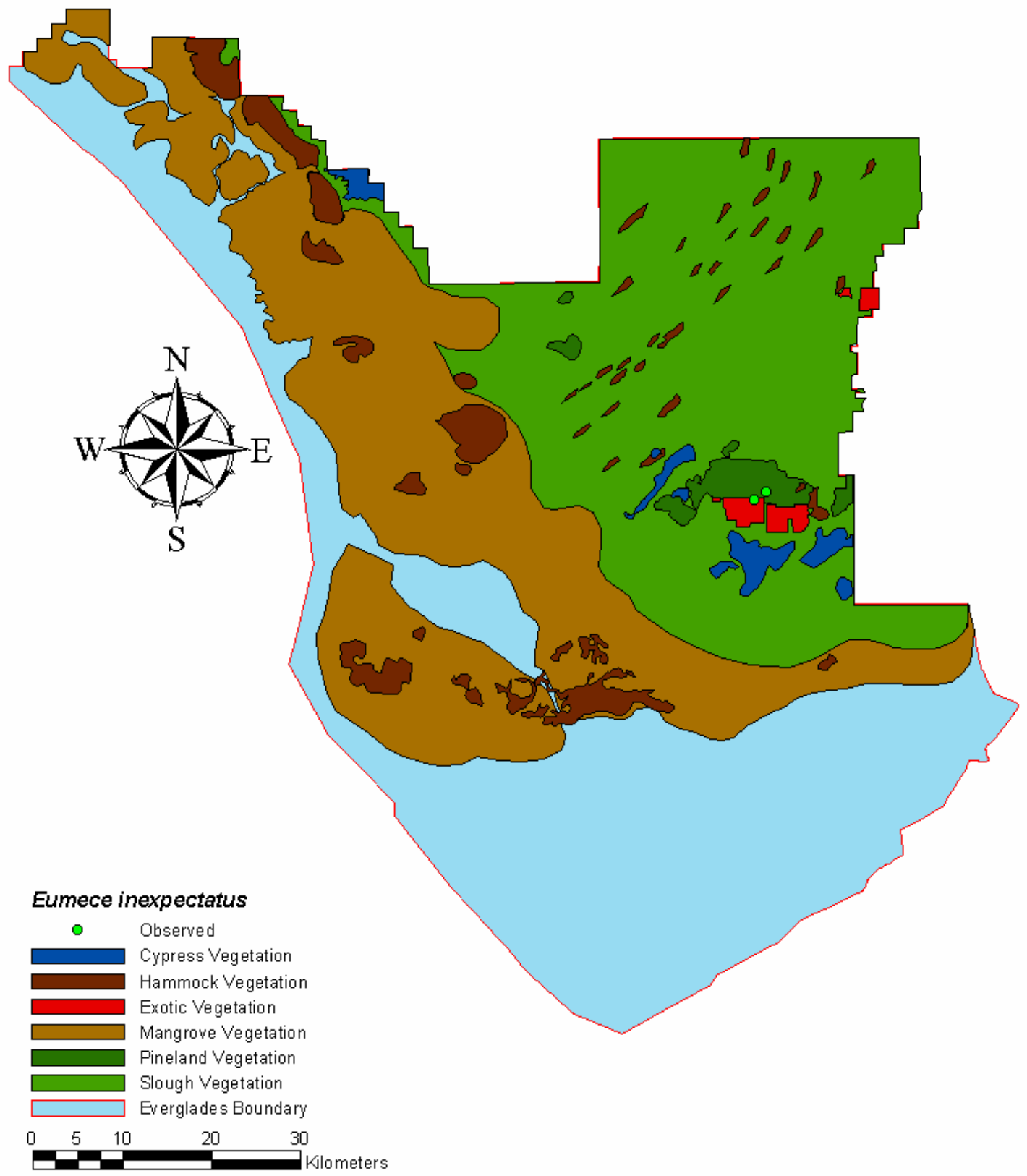

Figure 26: Eumeces inexpectatus locations

Map of all locations at which Eumeces inexpectatus were observed in Everglades National Park. 
Amphibians of Everglades National Park

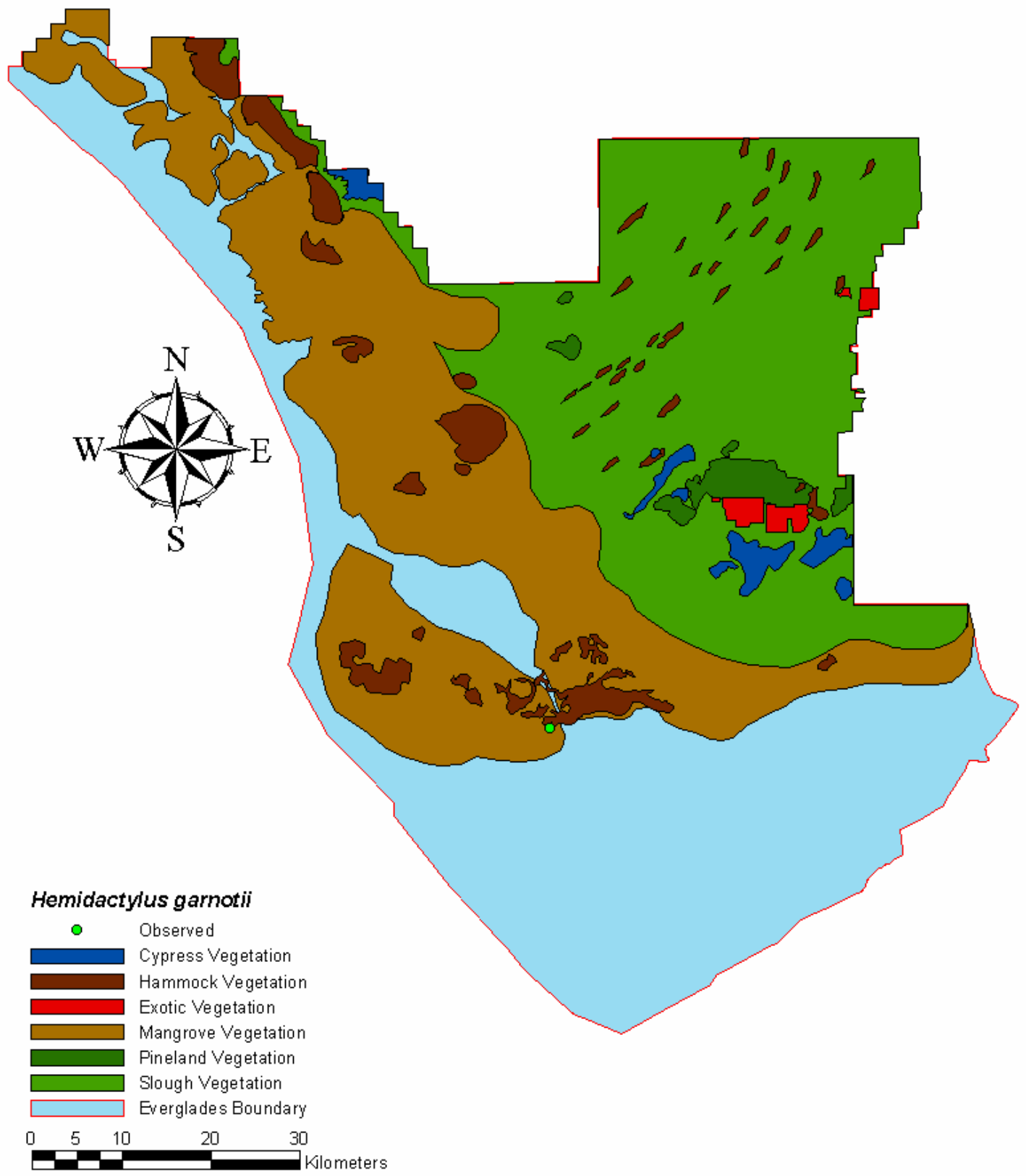

Figure 27: Hemidactylus garnotii locations

Map of all locations at which Hemidactylus garnotii were observed in Everglades National Park. 
Amphibians of Everglades National Park

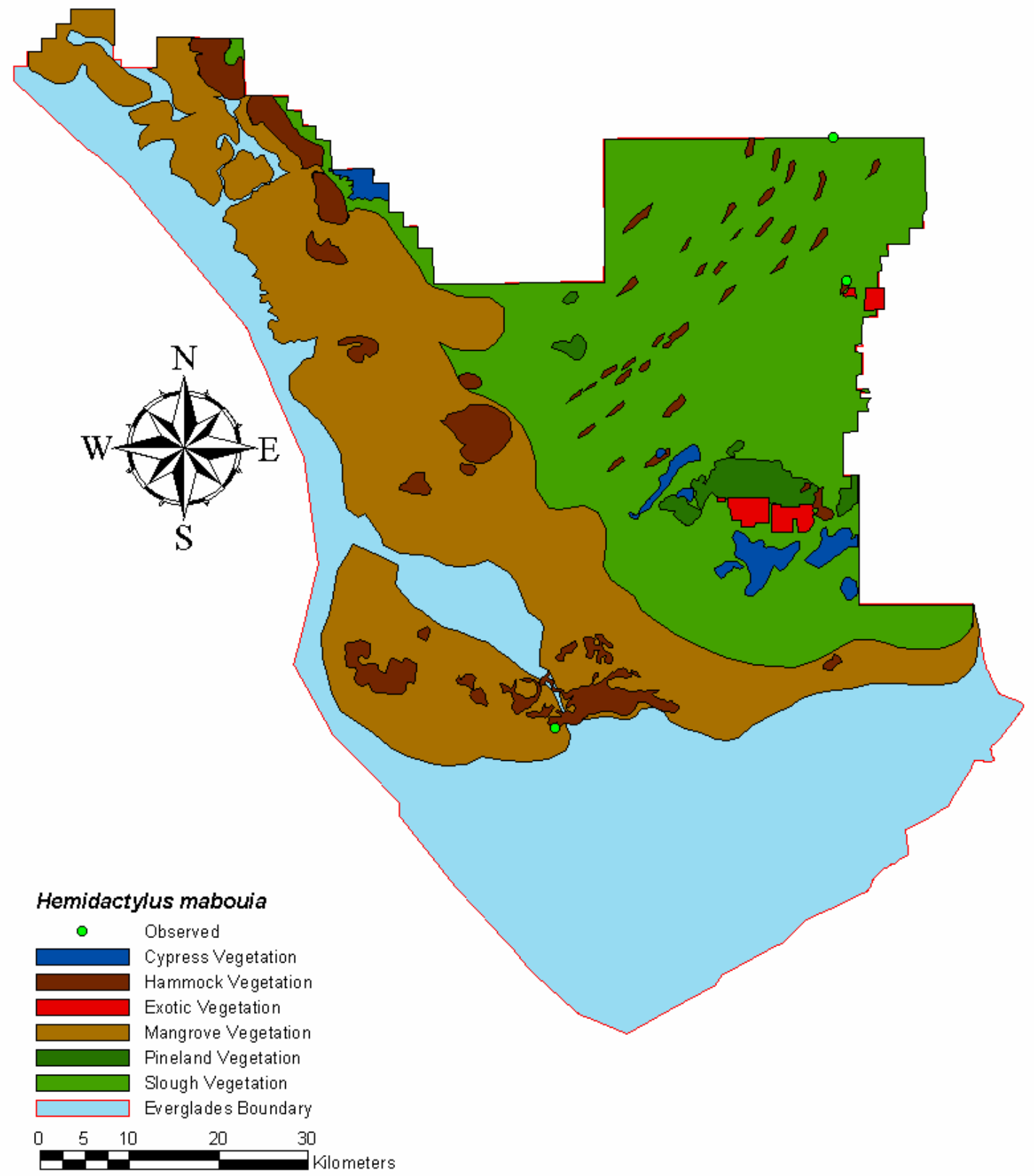

Figure 28: Hemidactylus mabouia locations

Map of all locations at which Hemidactylus mabouia were observed in Everglades National Park. 
Amphibians of Everglades National Park

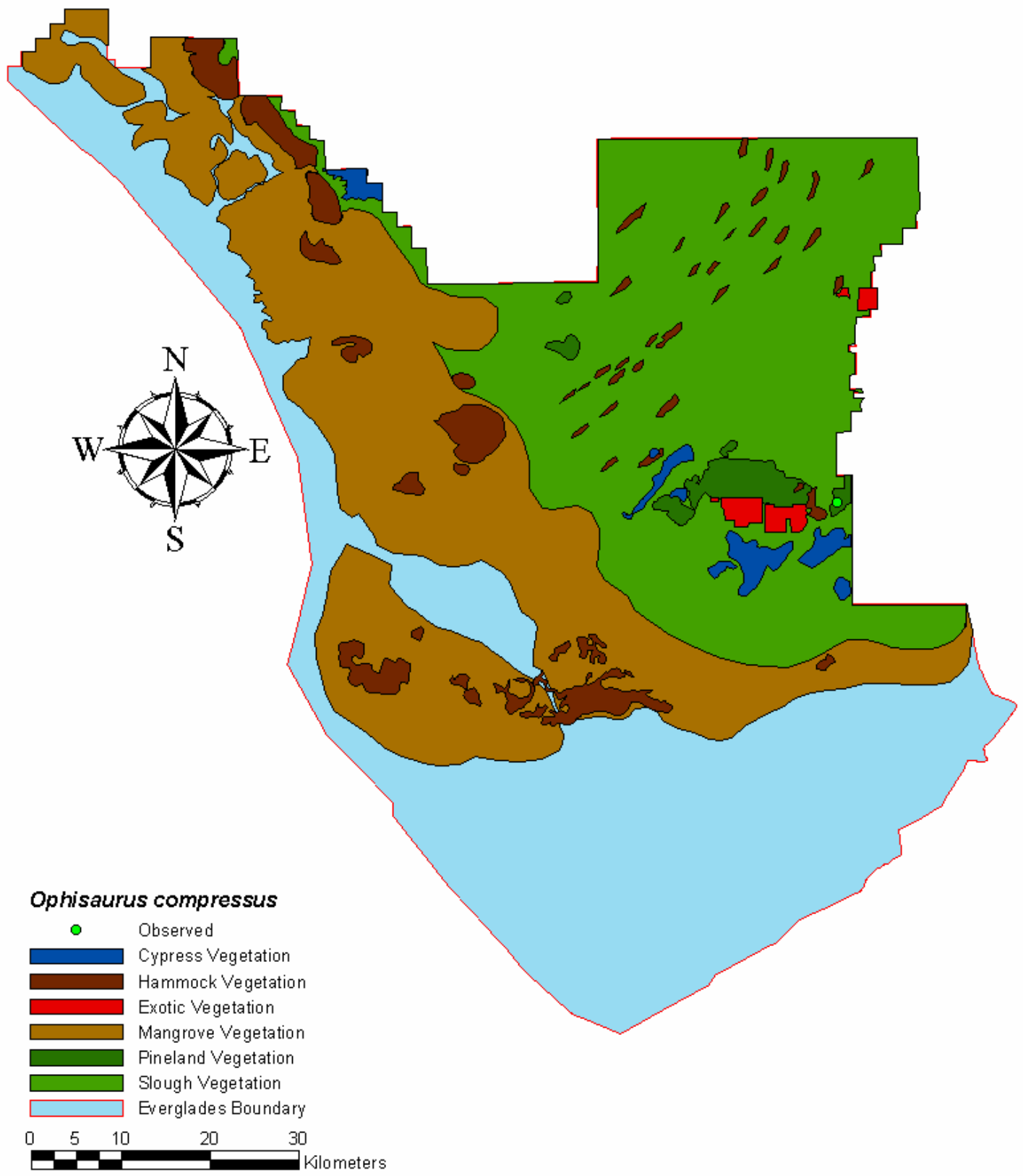

Figure 29: Ophisaurus compressus locations

Map of all locations at which Ophisaurus compressus were observed in Everglades National Park. 
Amphibians of Everglades National Park

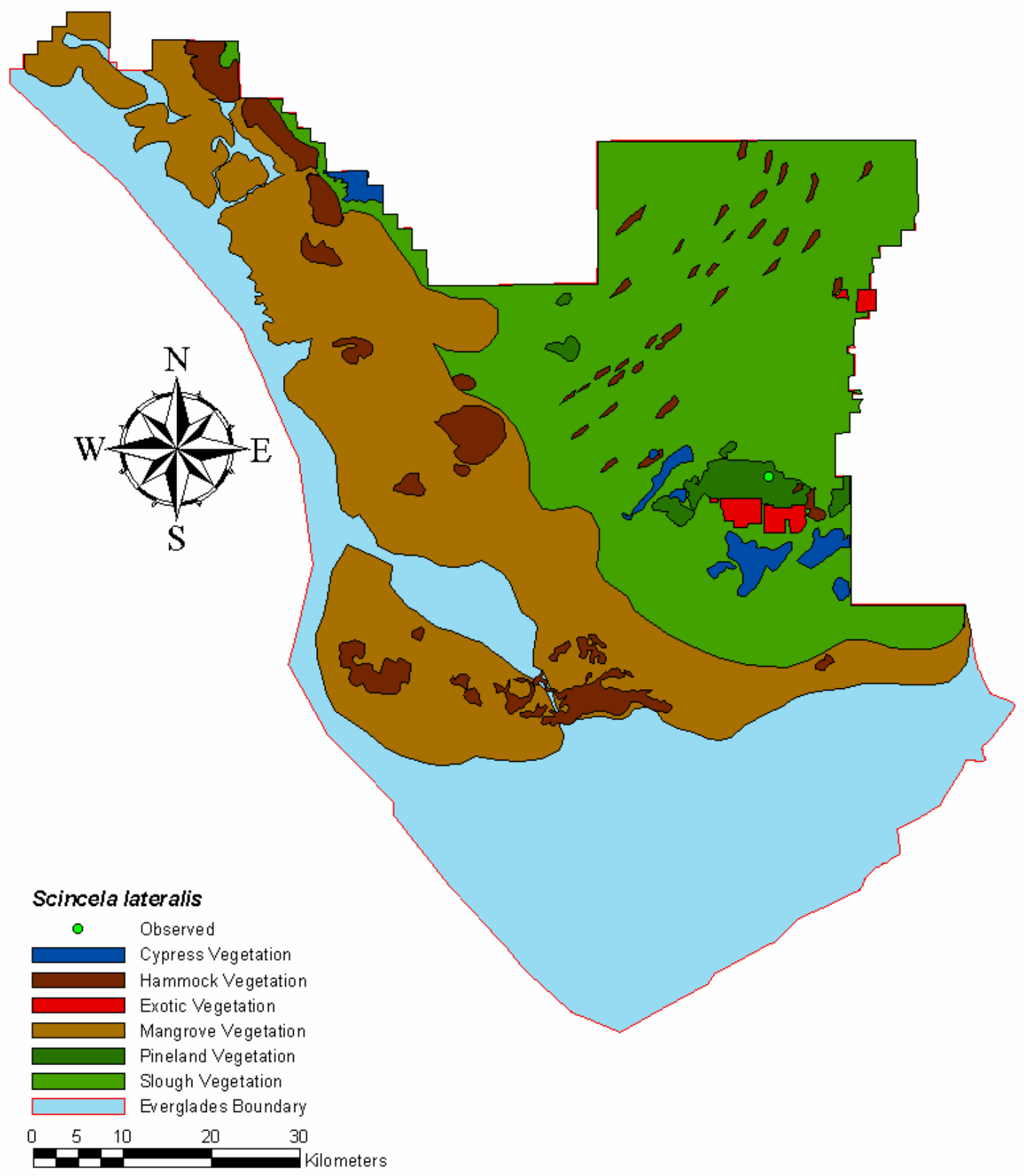

Figure 30: Scincella lateralis locations

Map of all locations at which Scincella lateralis were observed in Everglades National Park. 
Amphibians of Everglades National Park

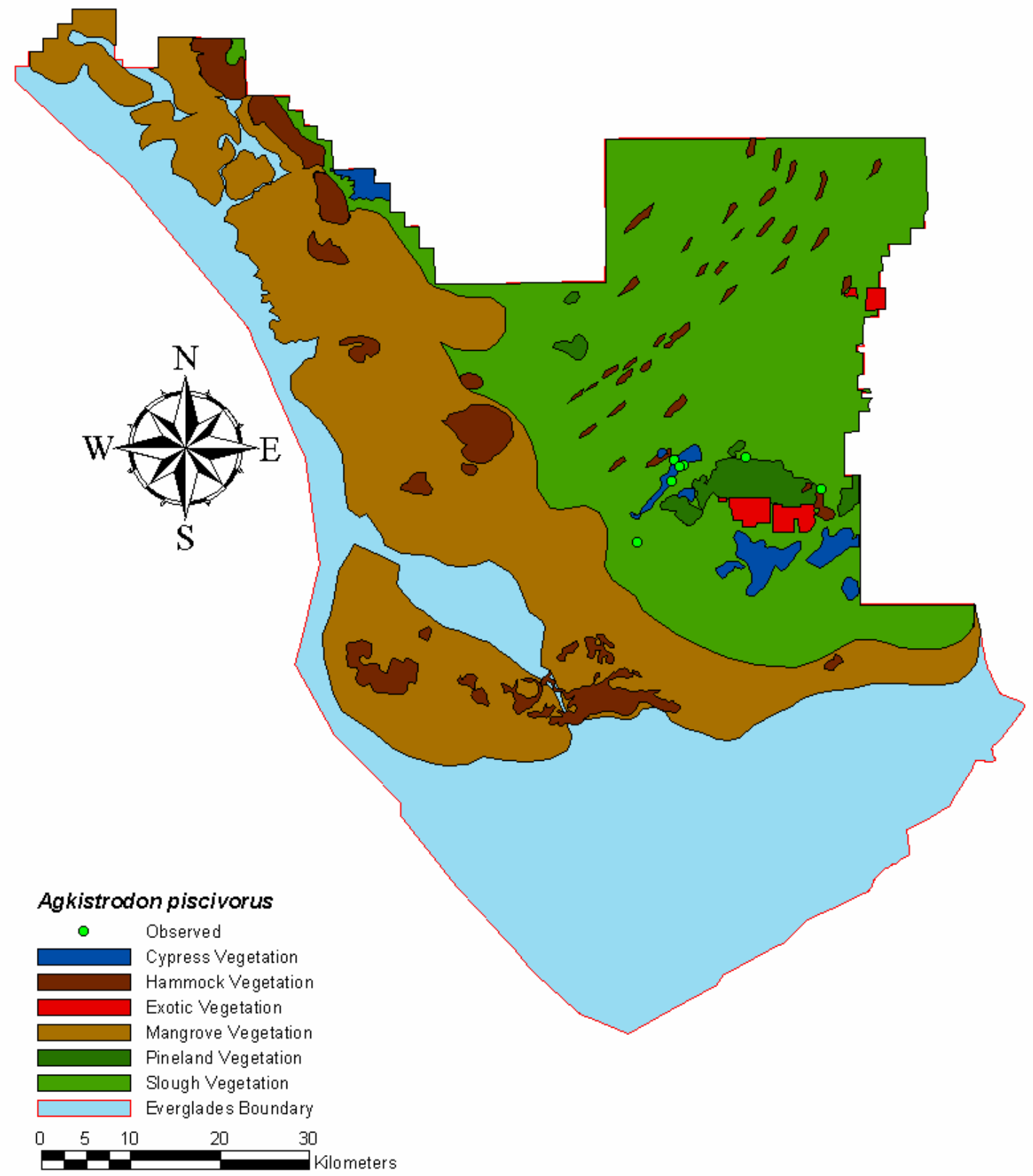

Figure 31: Agkistrodon piscivorus locations

Map of all locations at which Agkistrodon piscivorus were observed in Everglades National Park. 
Amphibians of Everglades National Park

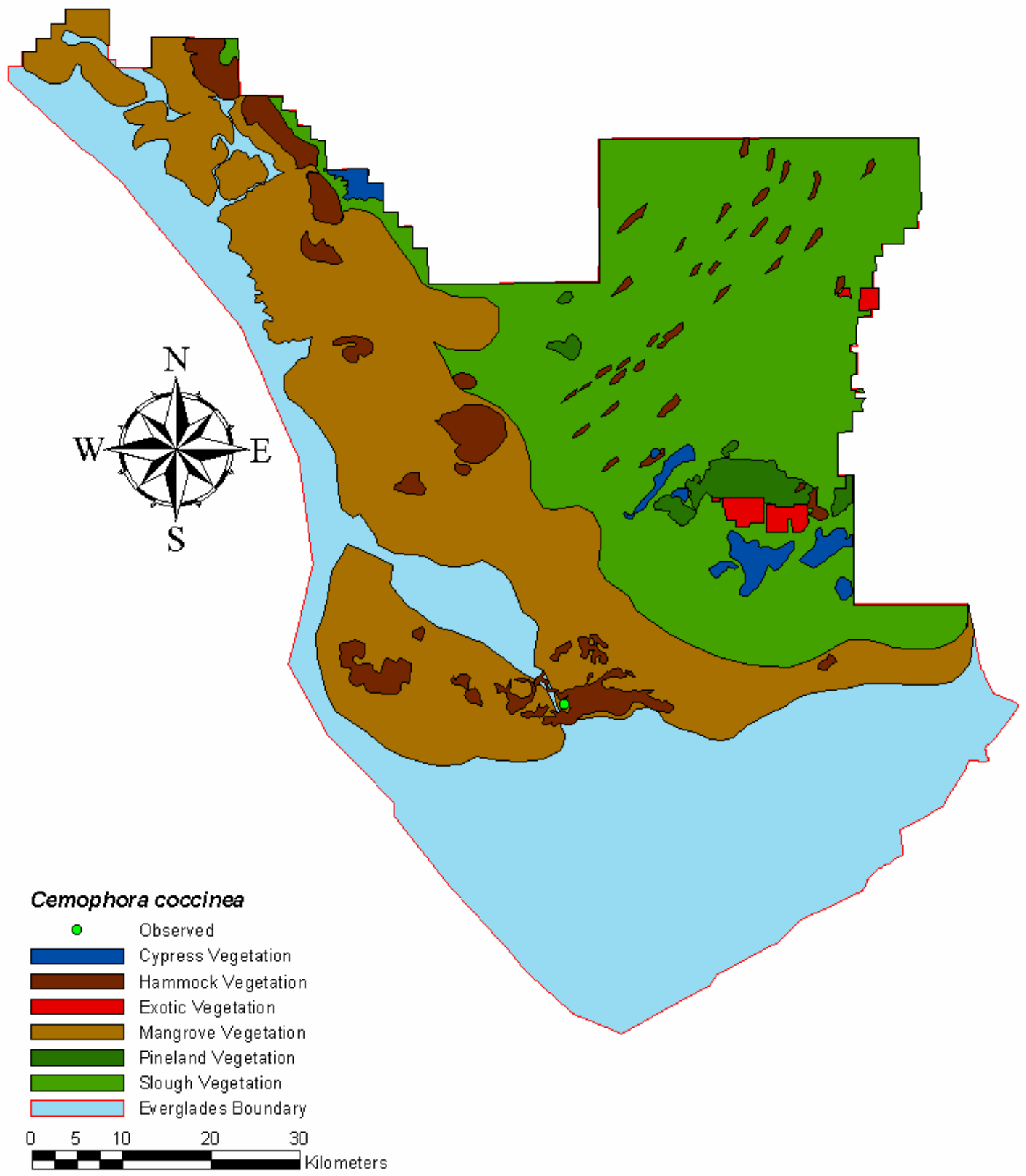

Figure 32: Cemophora coccinea locations

Map of all locations at which Cemophora coccinea were observed in Everglades National Park. 
Amphibians of Everglades National Park

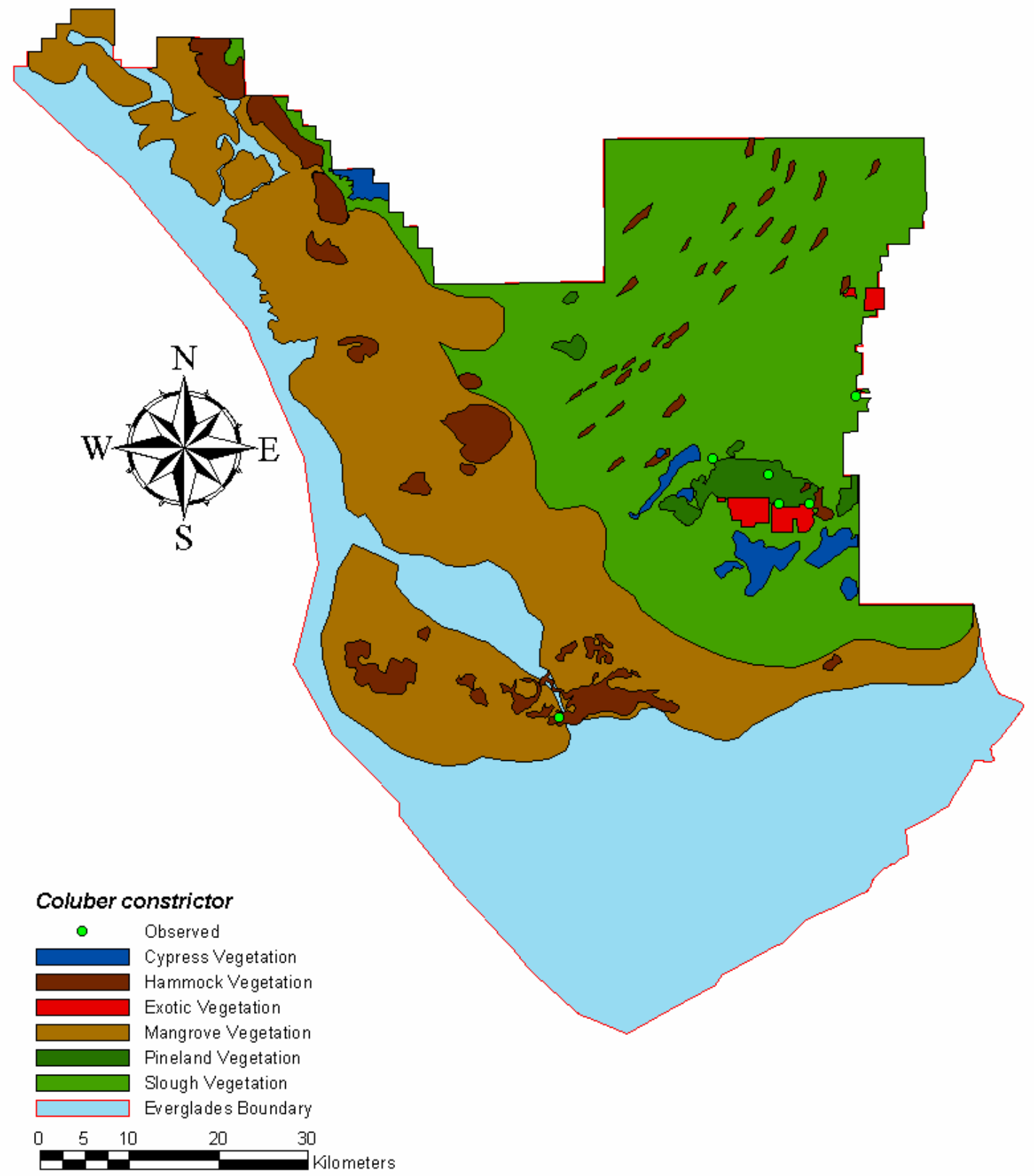

Figure 33: Coluber constrictor locations

Map of all locations at which Coluber constrictor were observed in Everglades National Park. 
Amphibians of Everglades National Park

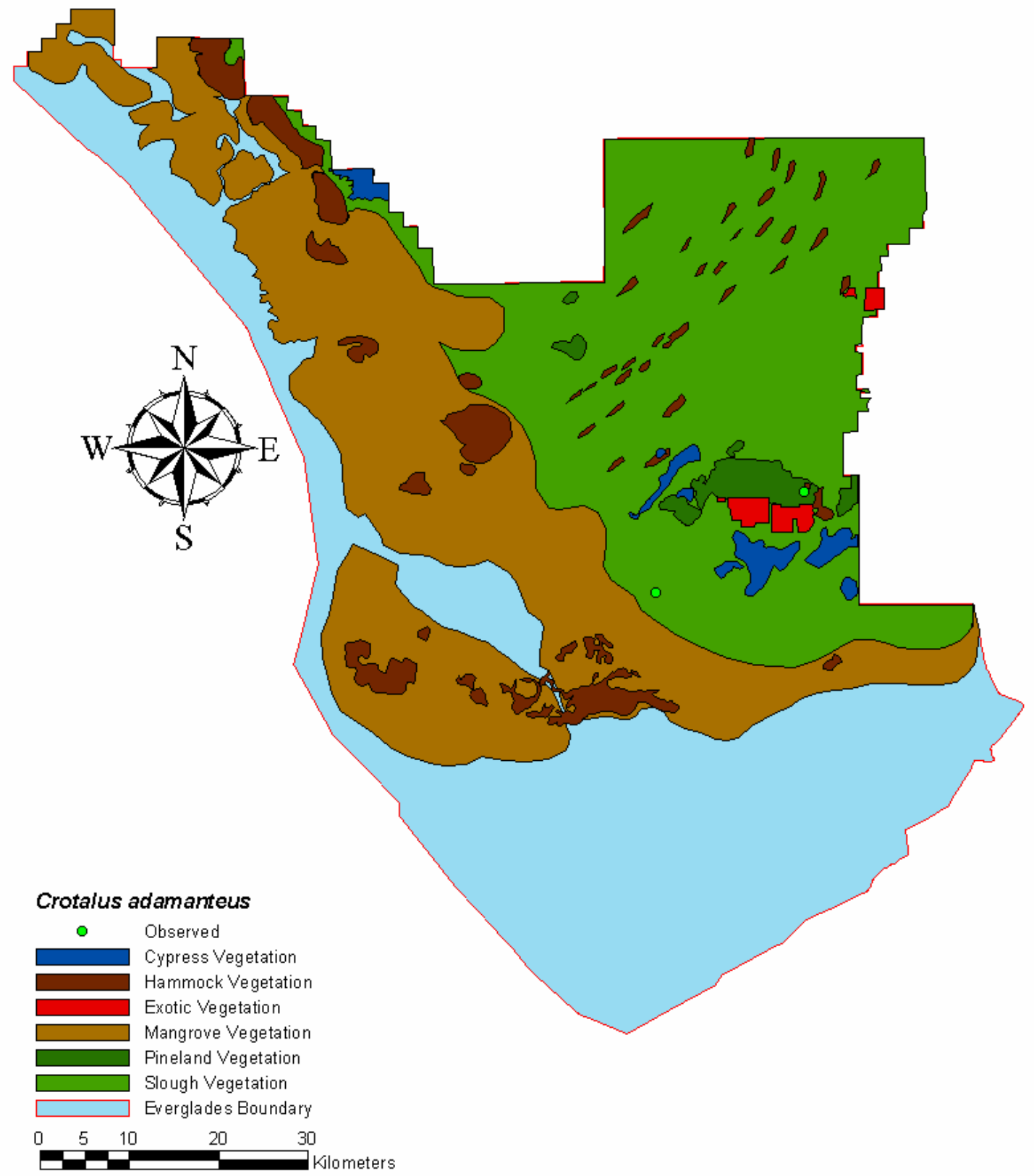

Figure 34: Crotalus adamanteus locations

Map of all locations at which Crotalus adamanteus were observed in Everglades National Park. 
Amphibians of Everglades National Park

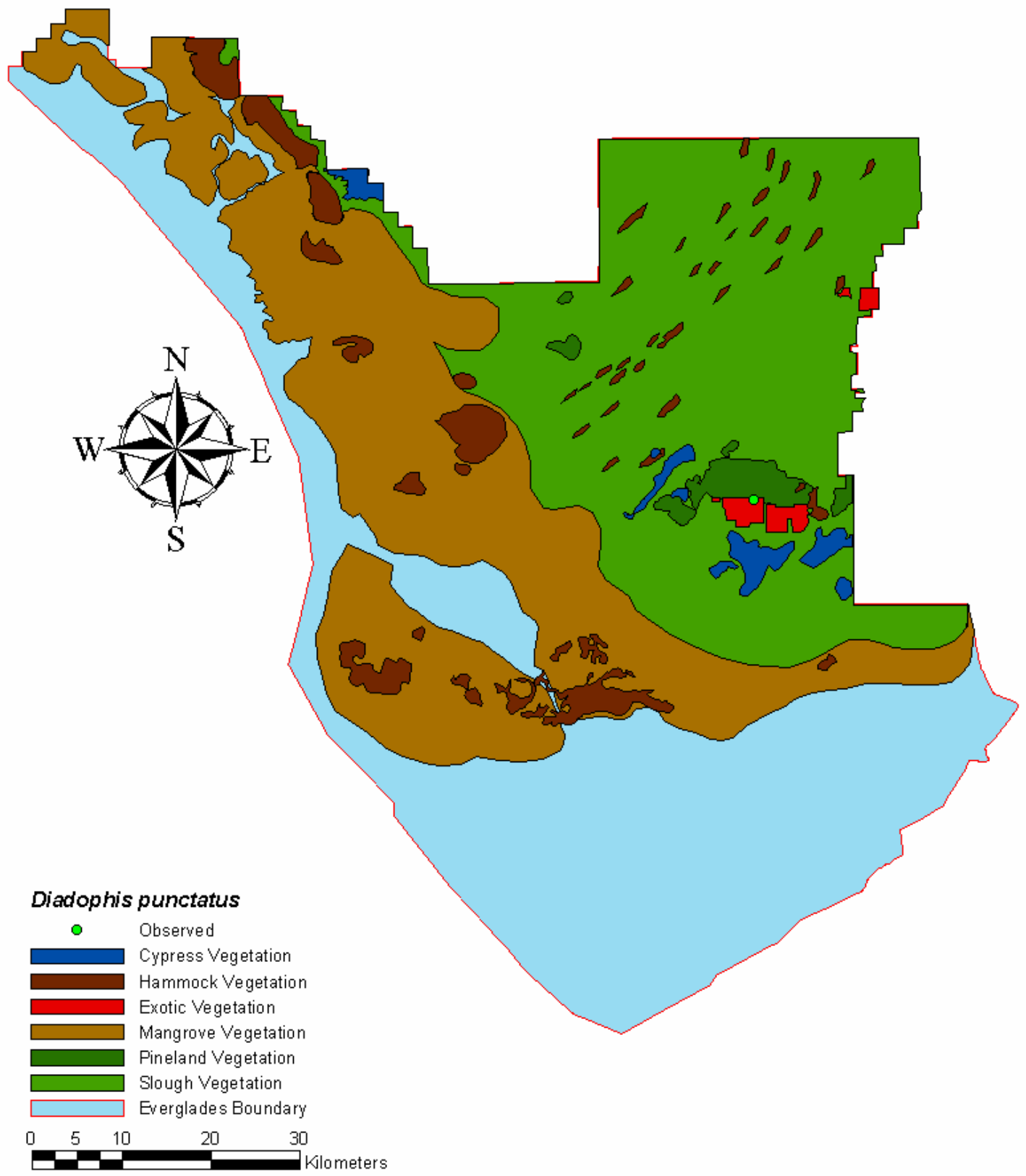

Figure 35: Diadophis punctatus

Map of all locations at which Diadophis punctatus were observed in Everglades National Park. 
Amphibians of Everglades National Park

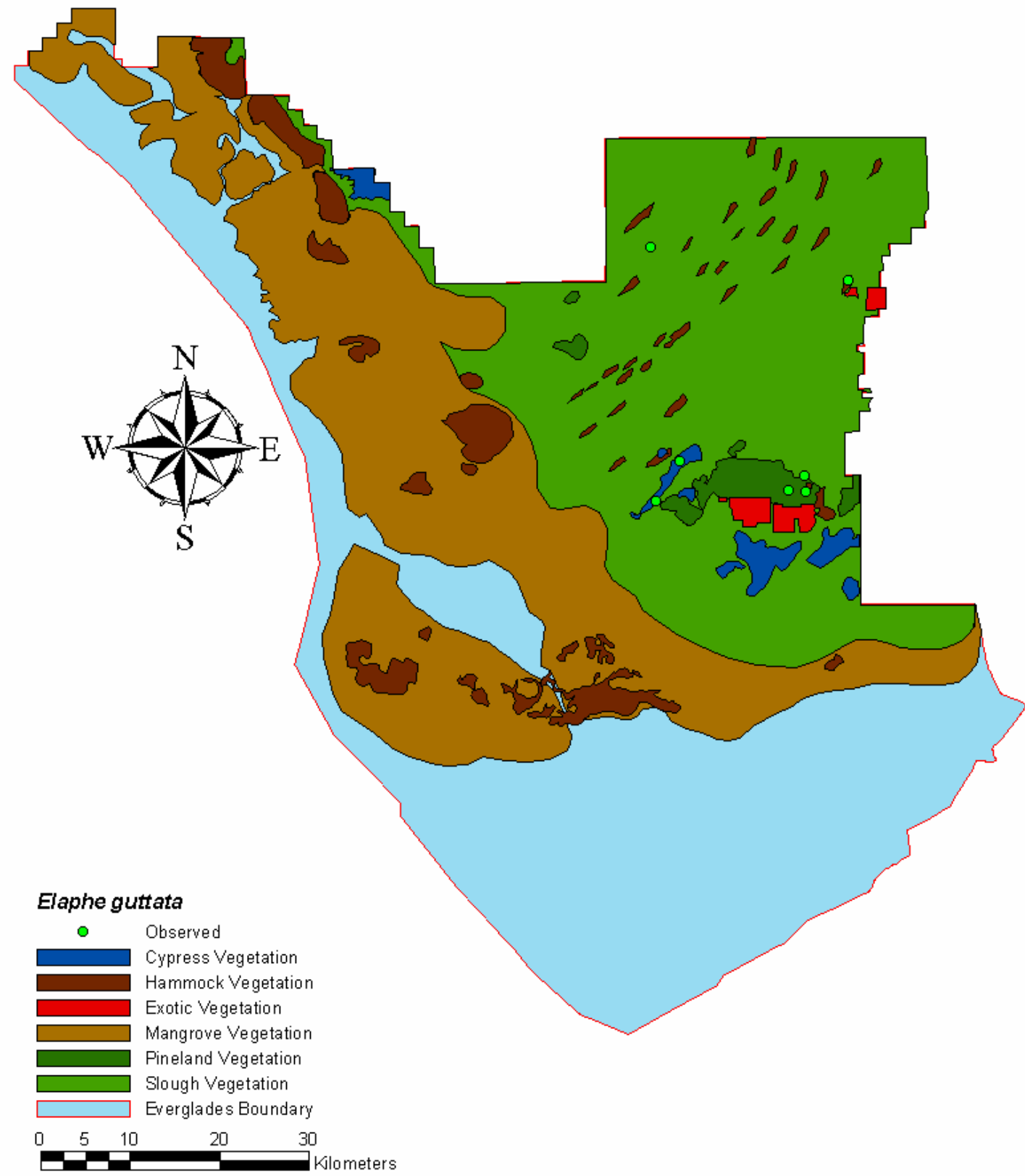

Figure 36: Elaphe guttata locations

Map of all locations at which Elaphe guttata were observed in Everglades National Park. 
Amphibians of Everglades National Park

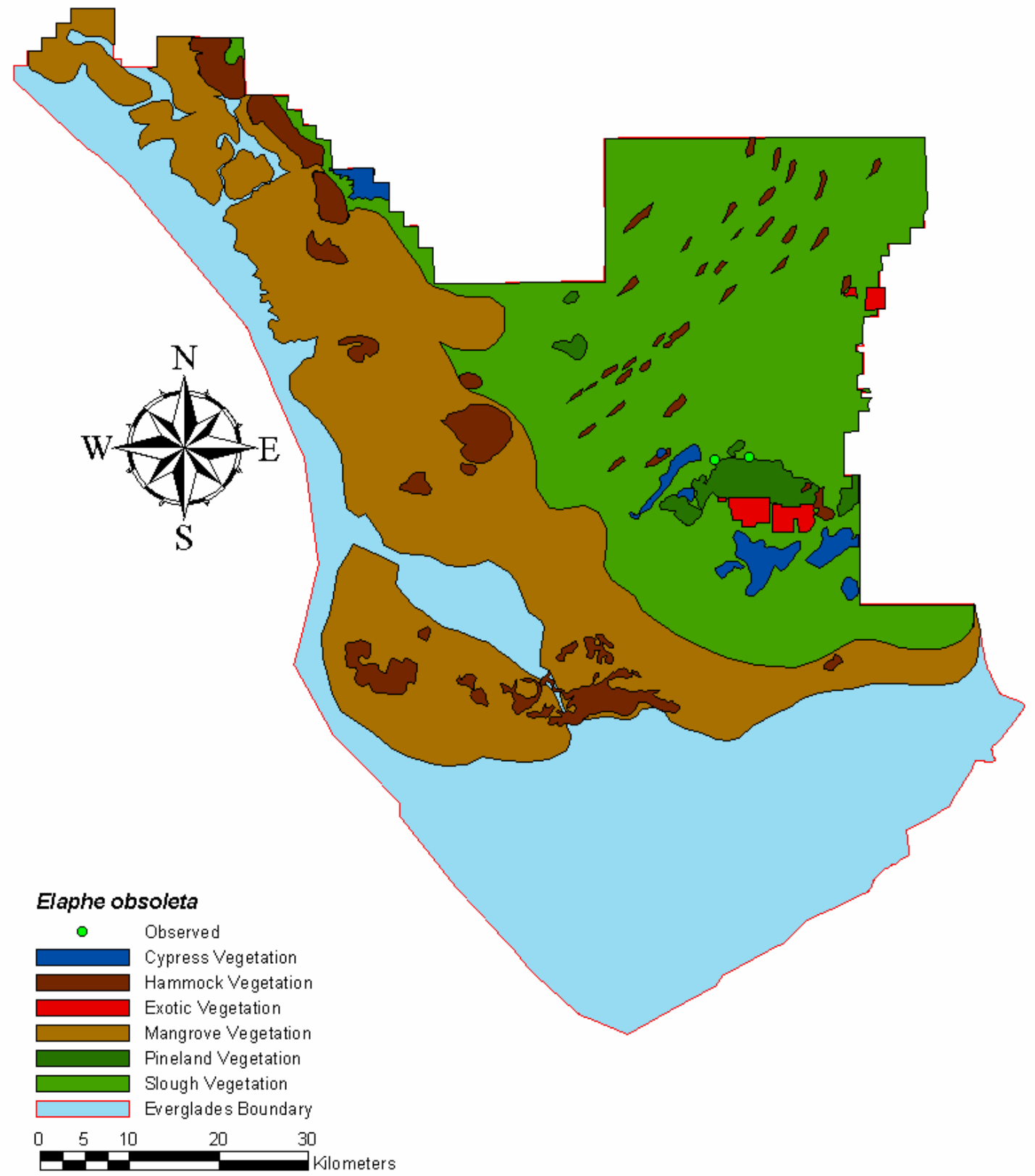

Figure 37: Elaphe obsoleta locations

Map of all locations at which Elaphe obsoleta were observed in Everglades National Park. 
Amphibians of Everglades National Park

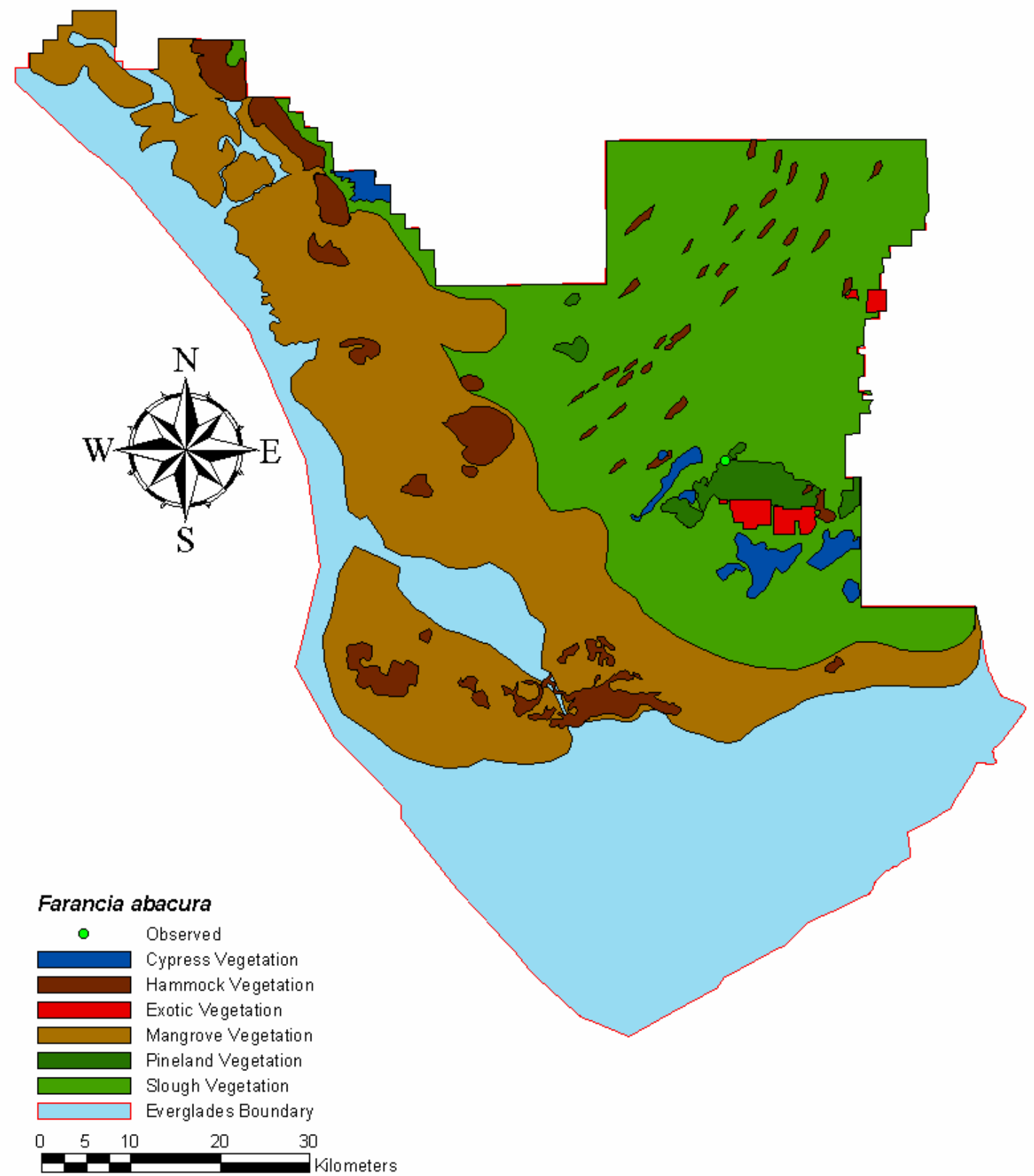

Figure 38: Farancia abacura locations

Map of all locations at which Farancia abacura were observed in Everglades National Park. 
Amphibians of Everglades National Park

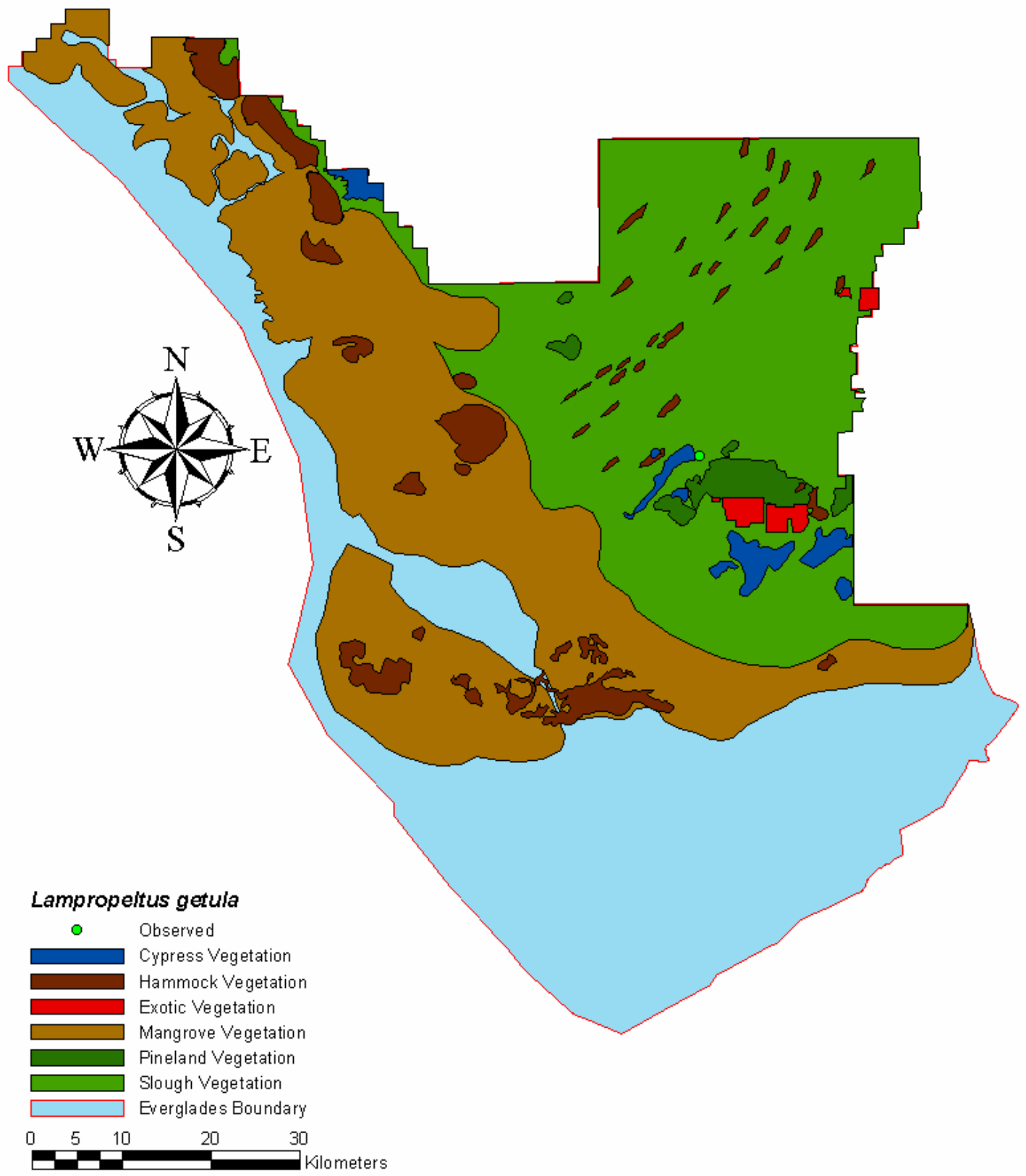

Figure 39: Lampropeltis getula locations

Map of all locations at which Lampropeltis getula were observed in Everglades National Park. 
Amphibians of Everglades National Park

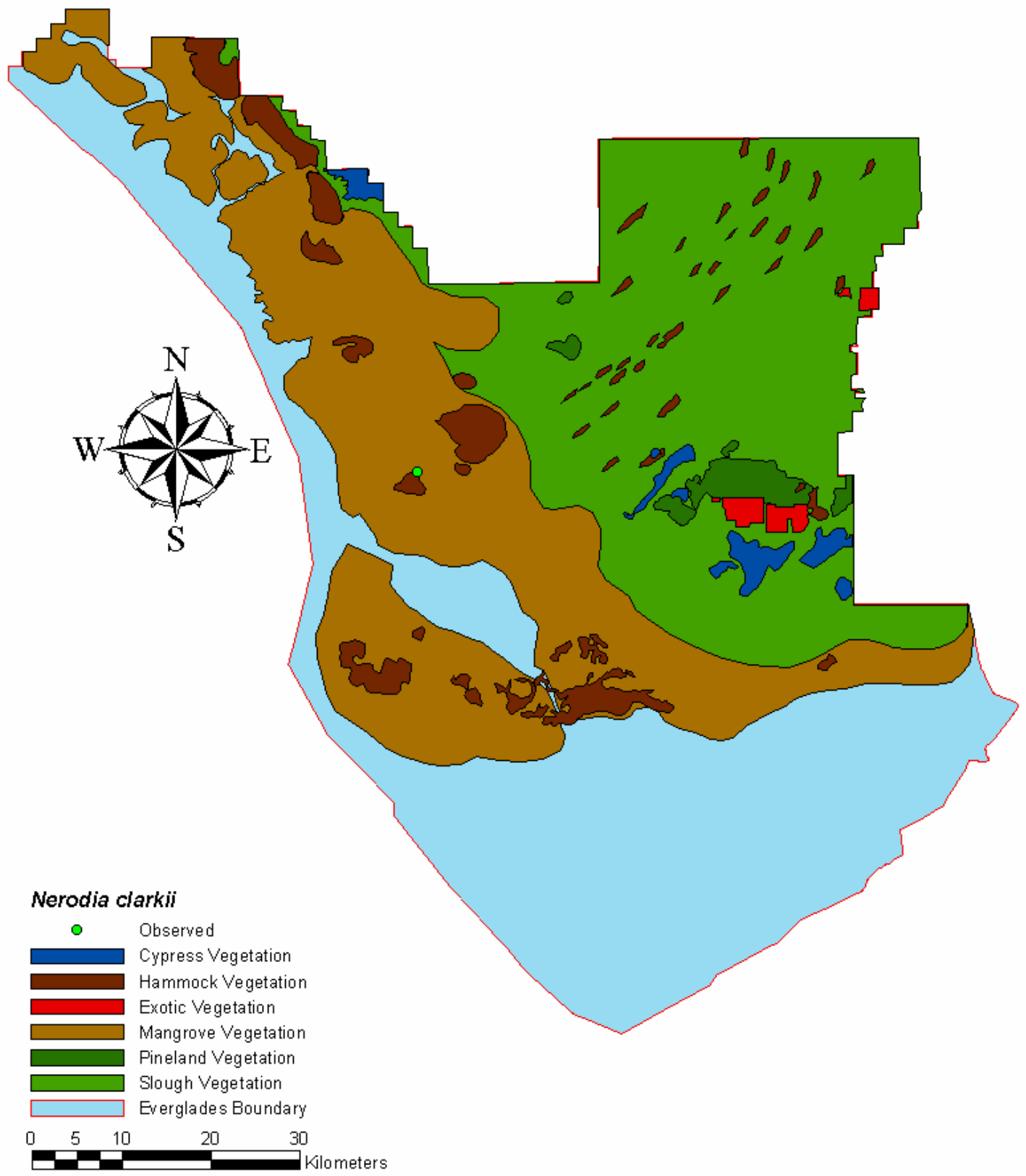

Figure 40: Nerodia clarkii locations

Map of all locations at which Nerodia clarkii were observed in Everglades National Park. 
Amphibians of Everglades National Park

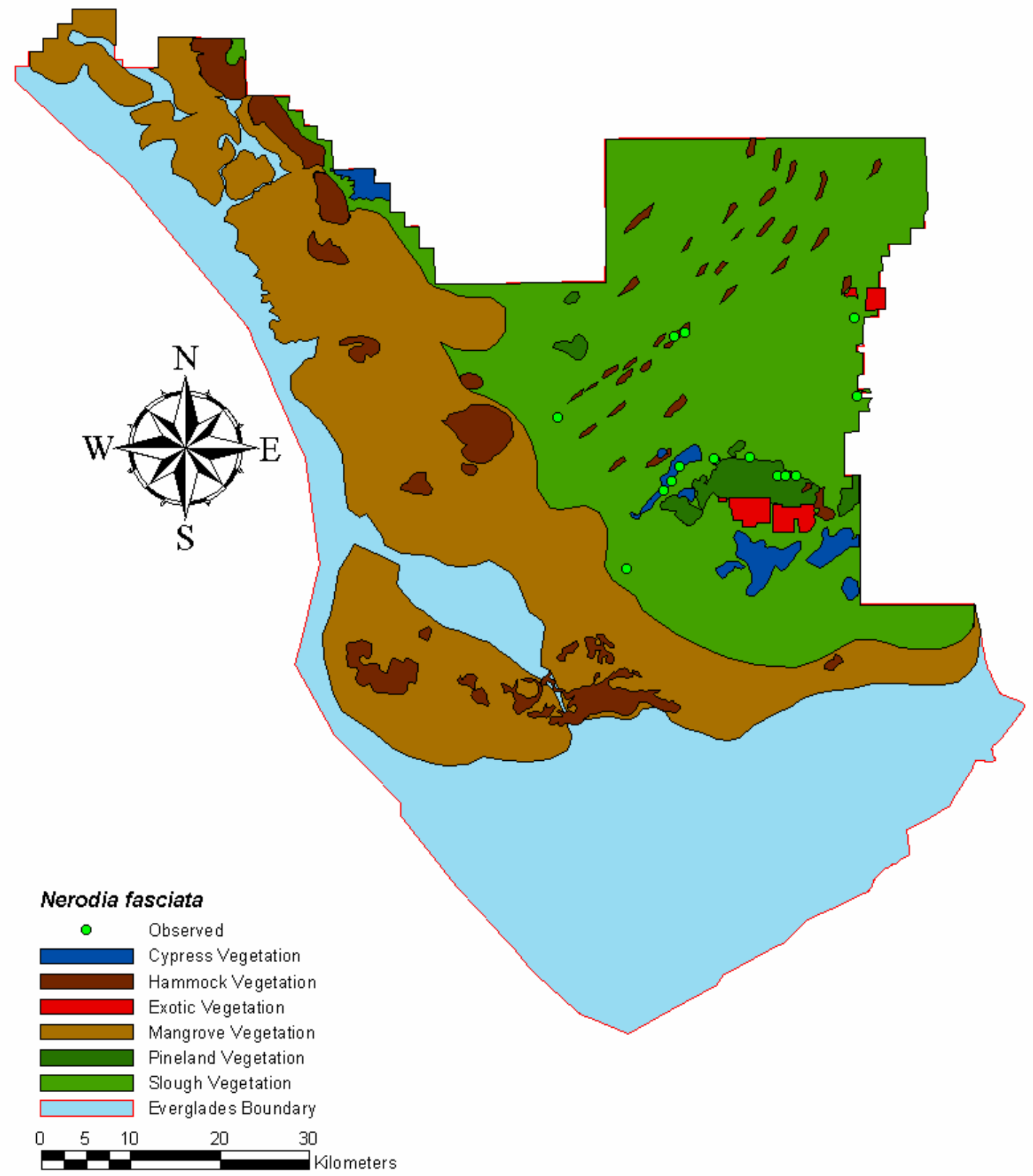

Figure 41: Nerodia fasciata locations

Map of all locations at which Nerodia fasciata were observed in Everglades National Park. 
Amphibians of Everglades National Park

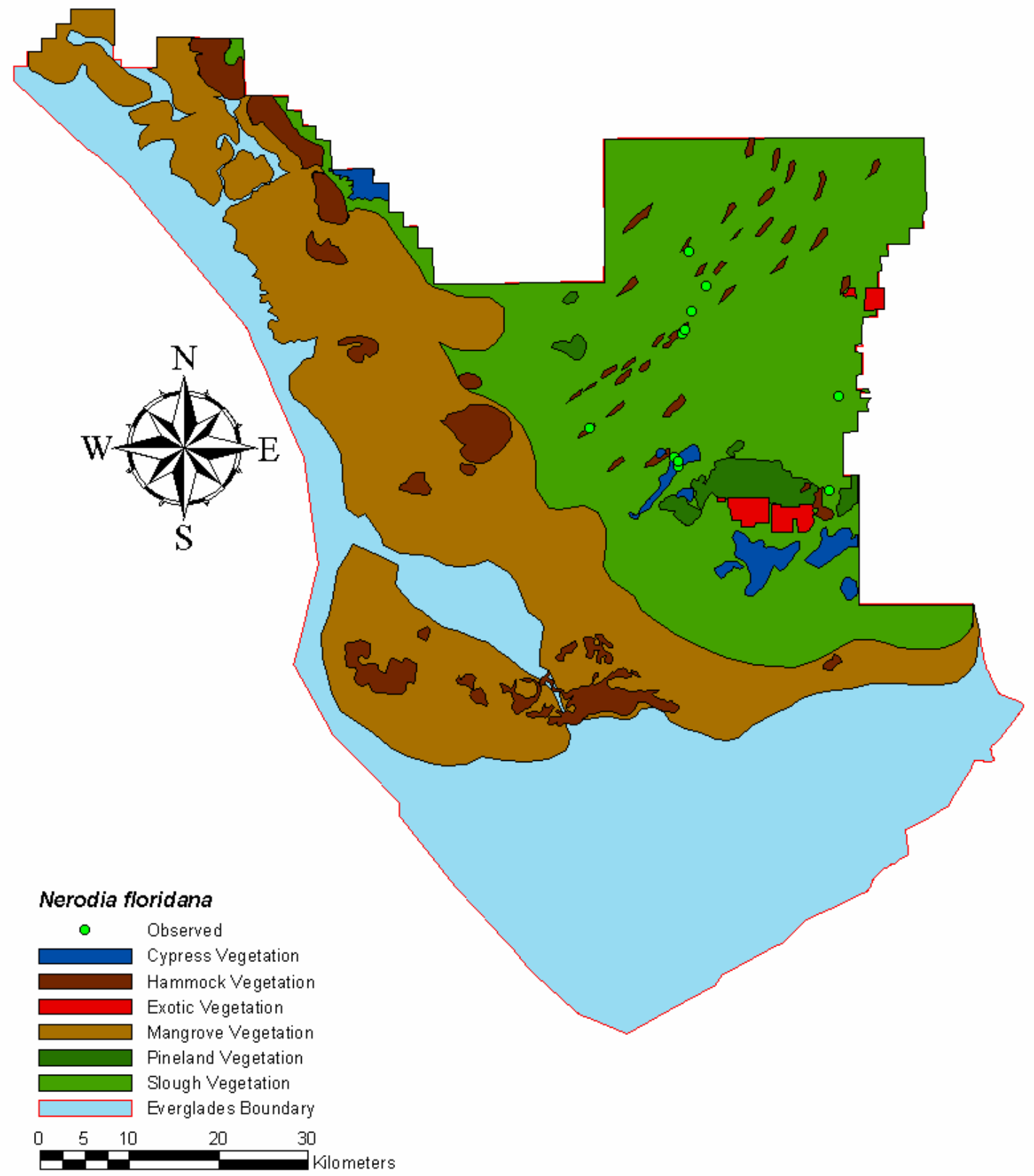

Figure 42: Nerodia floridana locations

Map of all locations at which Nerodia floridana were observed in Everglades National Park. 
Amphibians of Everglades National Park

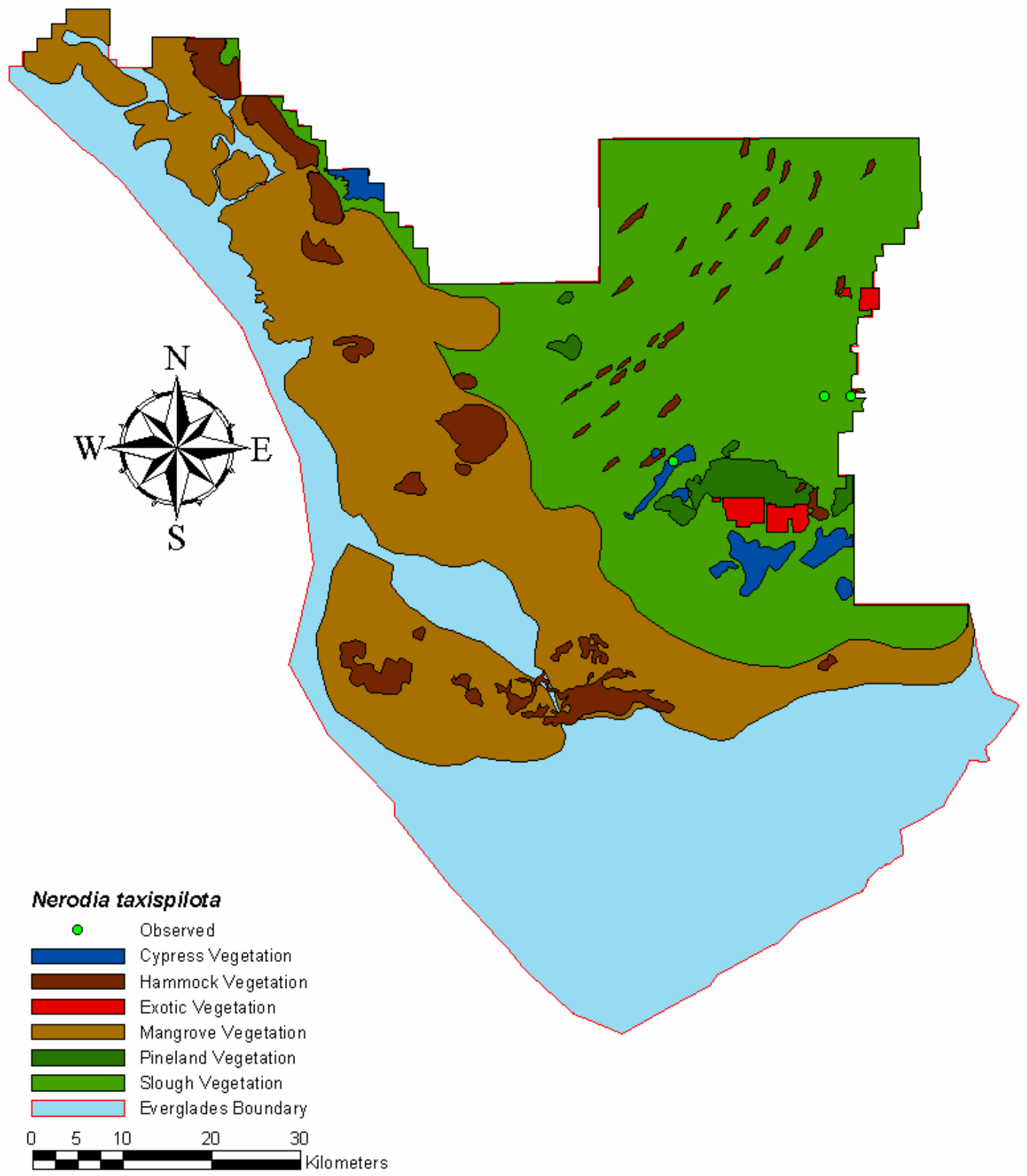

Figure 43: Nerodia taxispilota locations

Map of all locations at which Nerodia taxispilota were observed in Everglades National Park. 
Amphibians of Everglades National Park

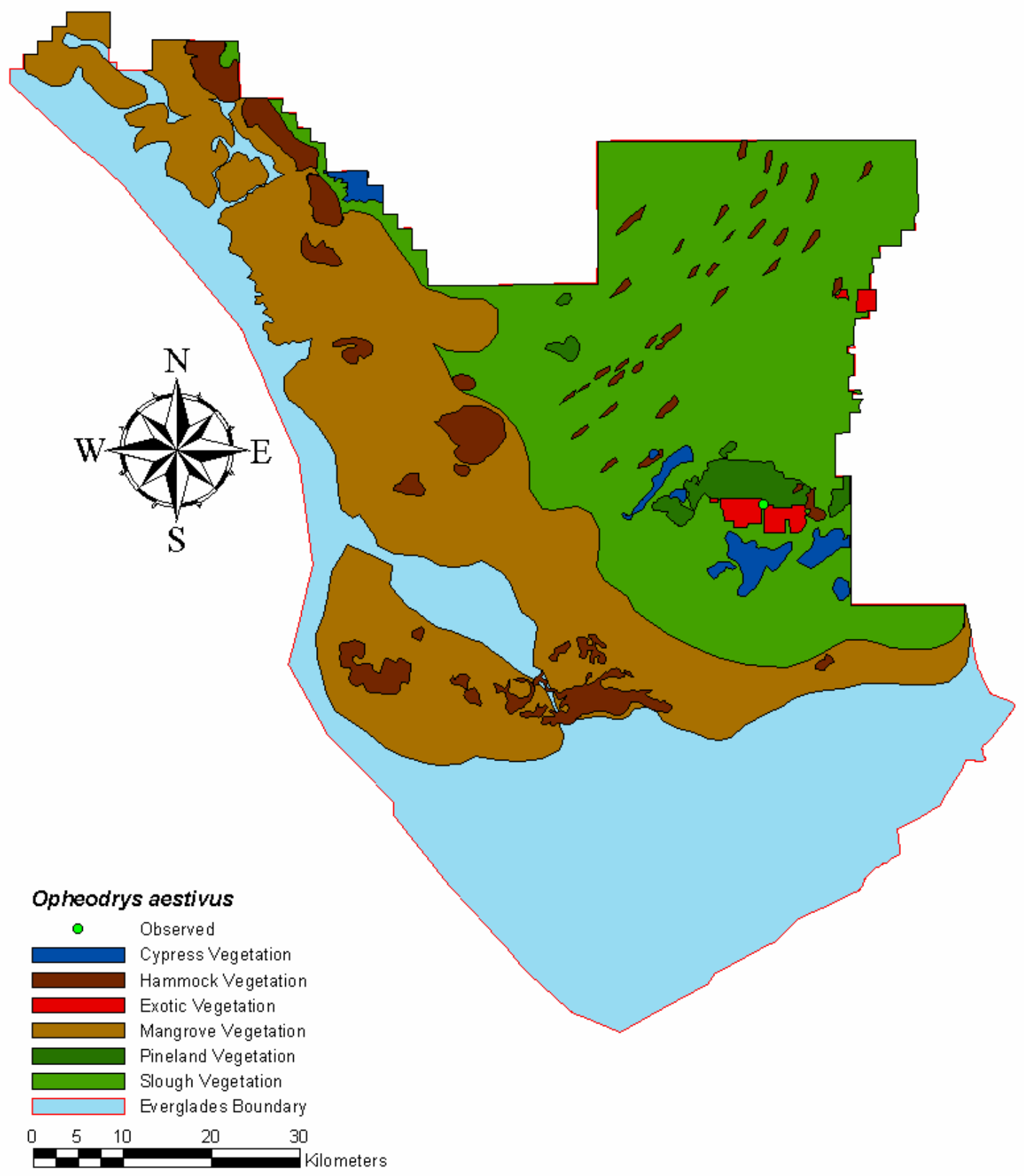

Figure 44: Opheodrys aestivus locations

Map of all locations at which Opheodrys aestivus were observed in Everglades National Park. 
Amphibians of Everglades National Park

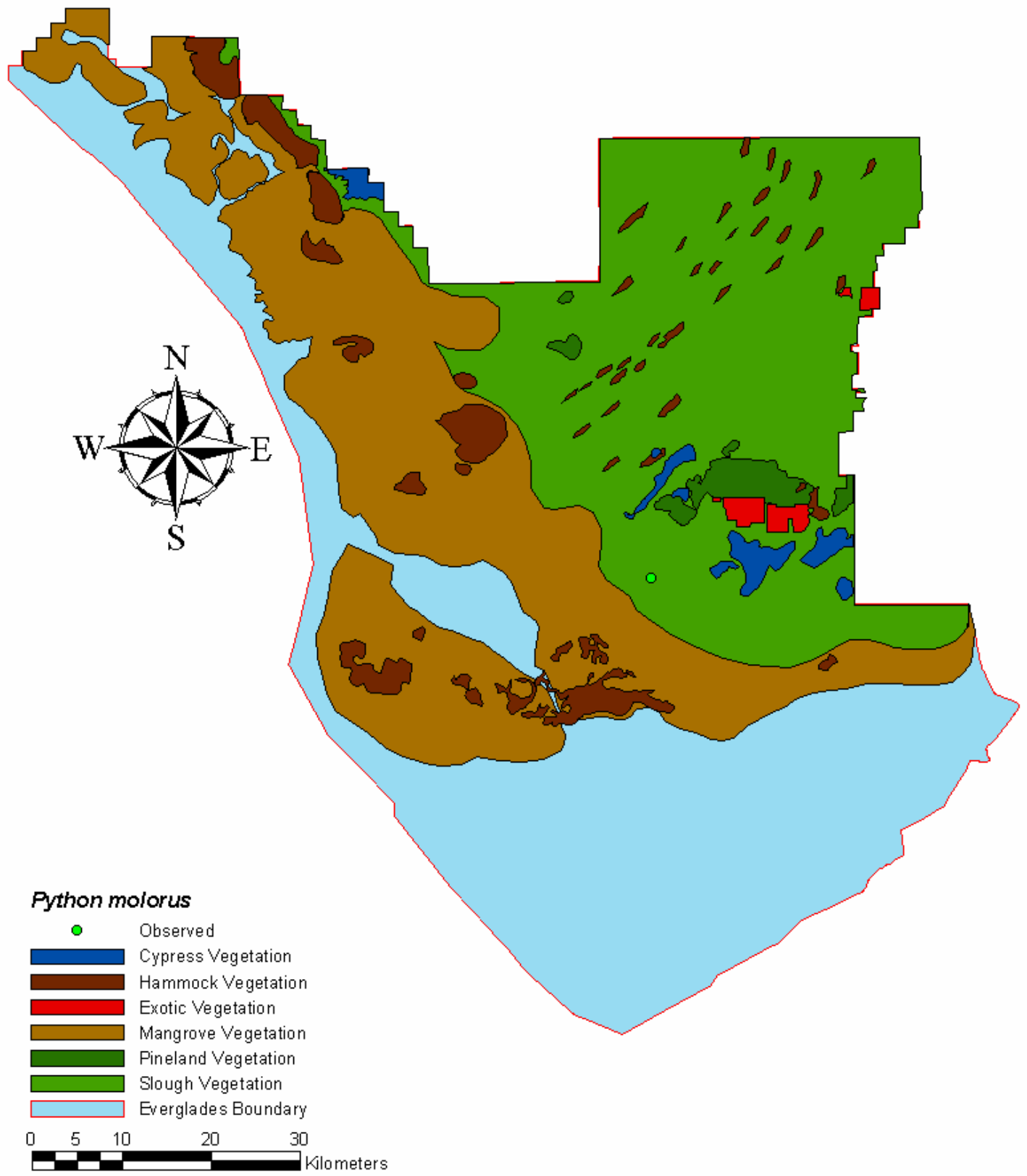

Figure 45: Python molorus locations

Map of all locations at which Python molorus were observed in Everglades National Park. 
Amphibians of Everglades National Park

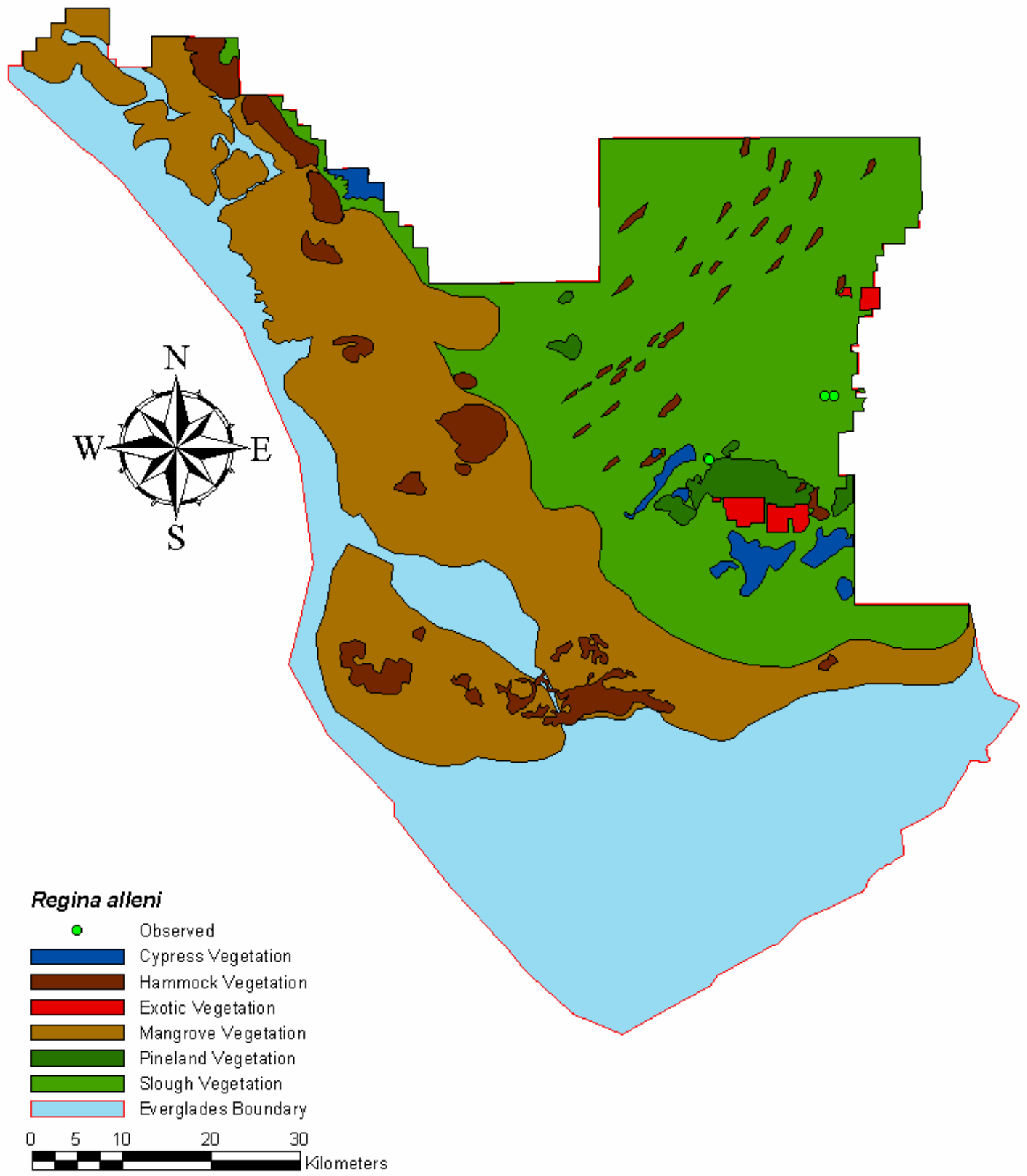

Figure 46: Regina alleni locations

Map of all locations at which Regina alleni were observed in Everglades National Park. 
Amphibians of Everglades National Park

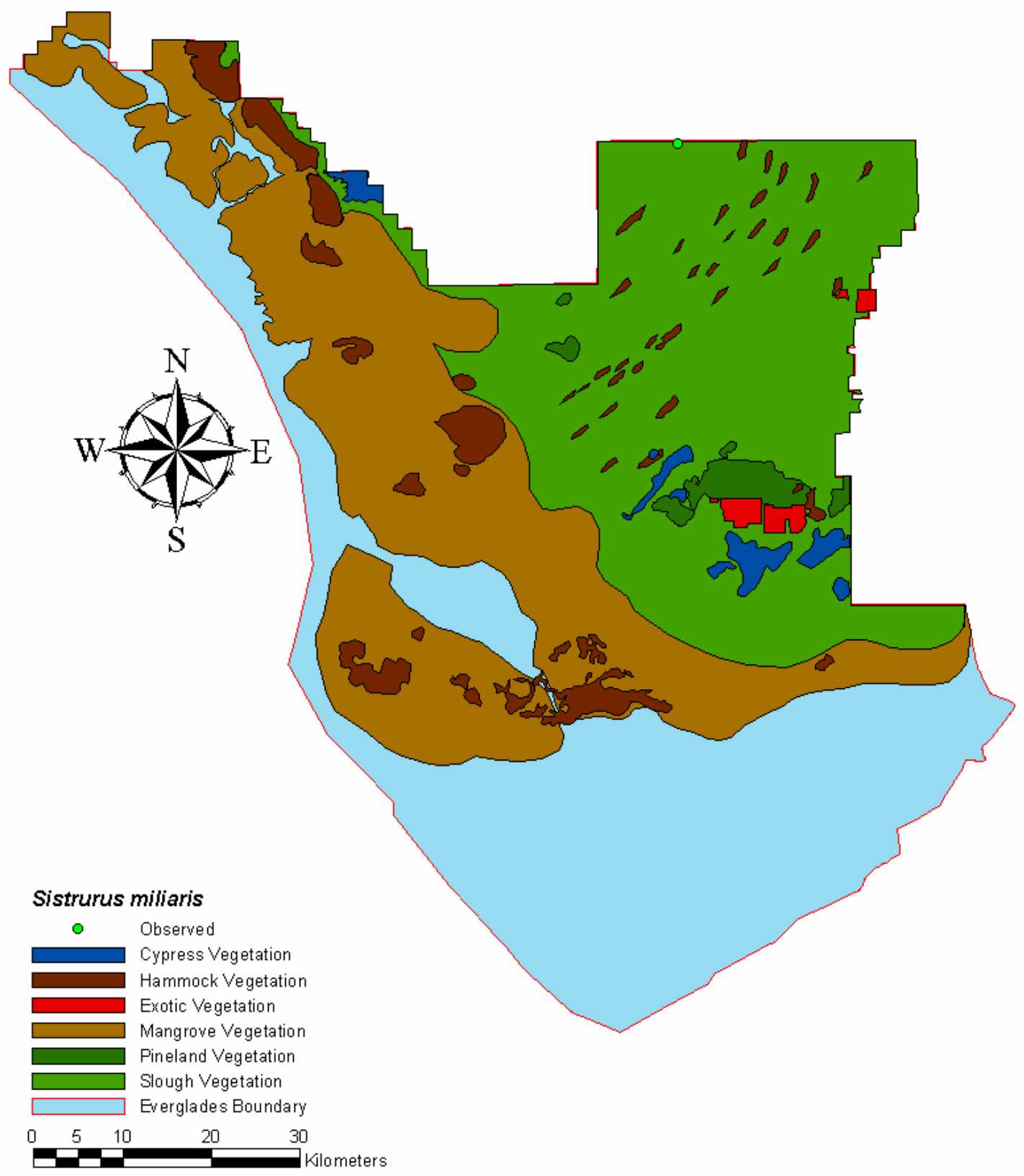

Figure 47: Sistrurus miliarius locations

Map of all locations at which Sistrurus miliarius were observed in Everglades National Park. 
Amphibians of Everglades National Park

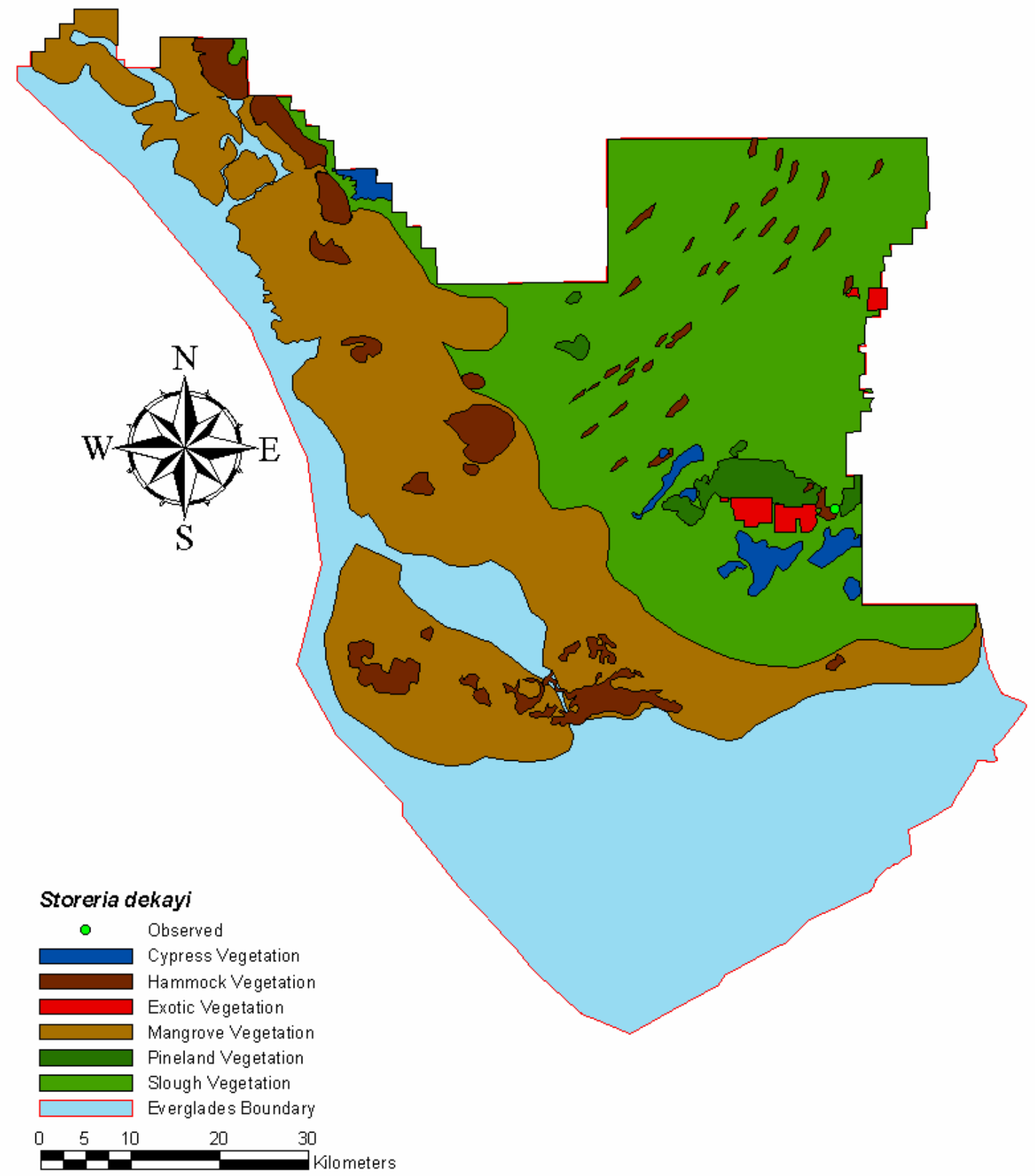

Figure 48: Storeria dekayi locations

Map of all locations at which Storeria dekayi were observed in Everglades National Park. 
Amphibians of Everglades National Park

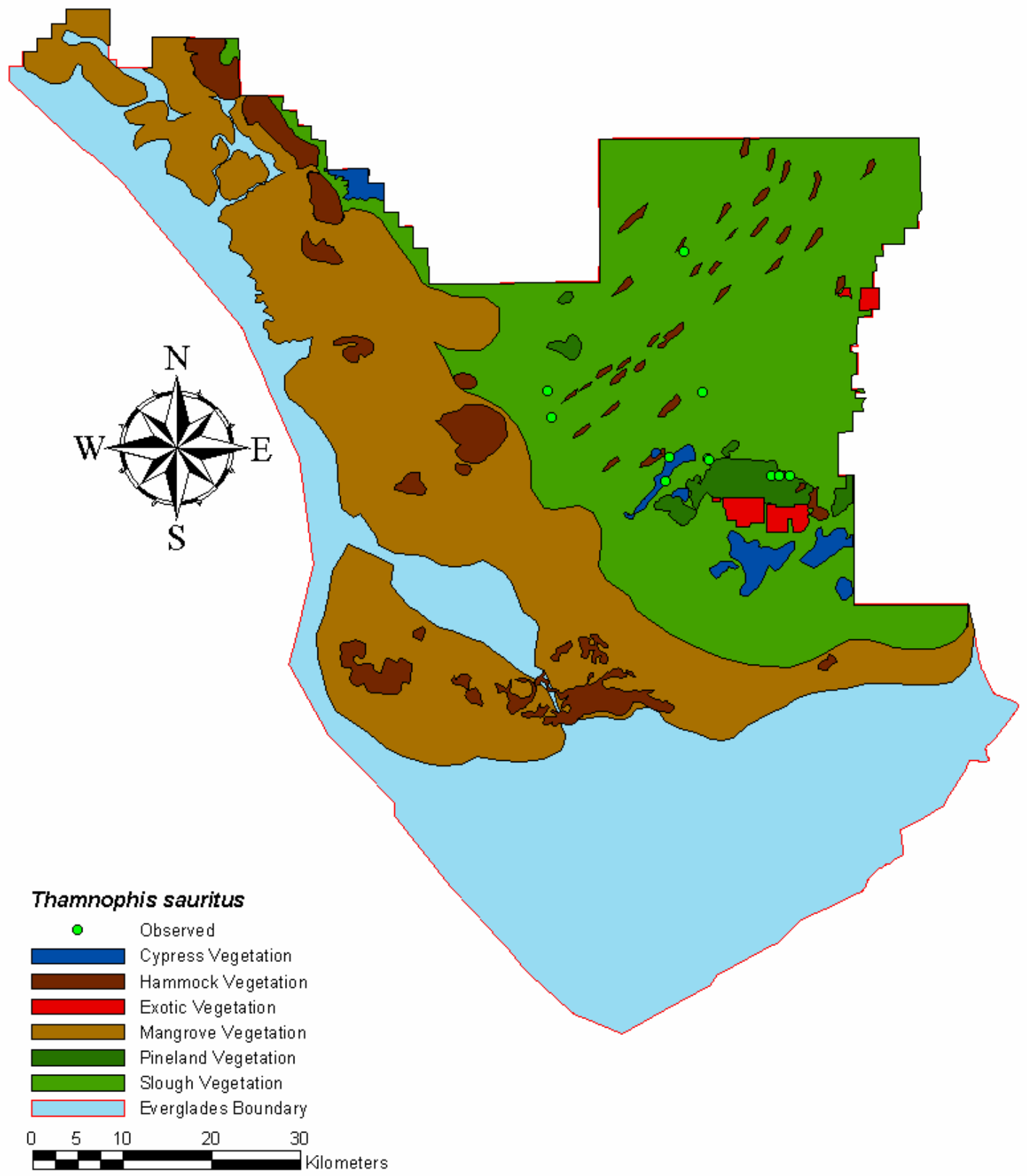

Figure 49: Thamnophis sauritus locations

Map of all locations at which Thamnophis sauritus were observed in Everglades National Park. 
Amphibians of Everglades National Park

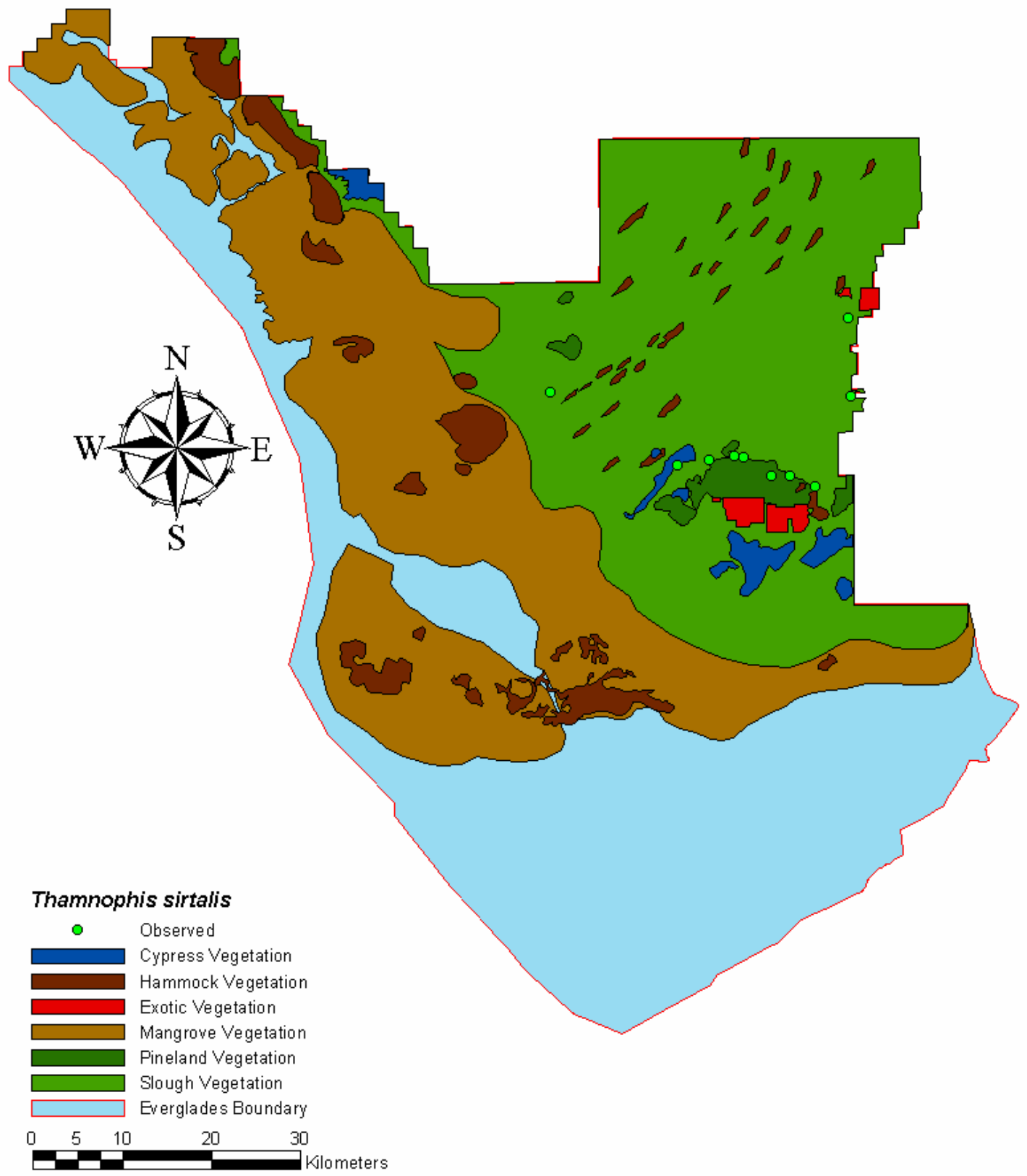

Figure 50: Thamnophis sirtalis locations

Map of all locations at which Thamnophis sirtalis were observed in Everglades National Park. 
Amphibians of Everglades National Park

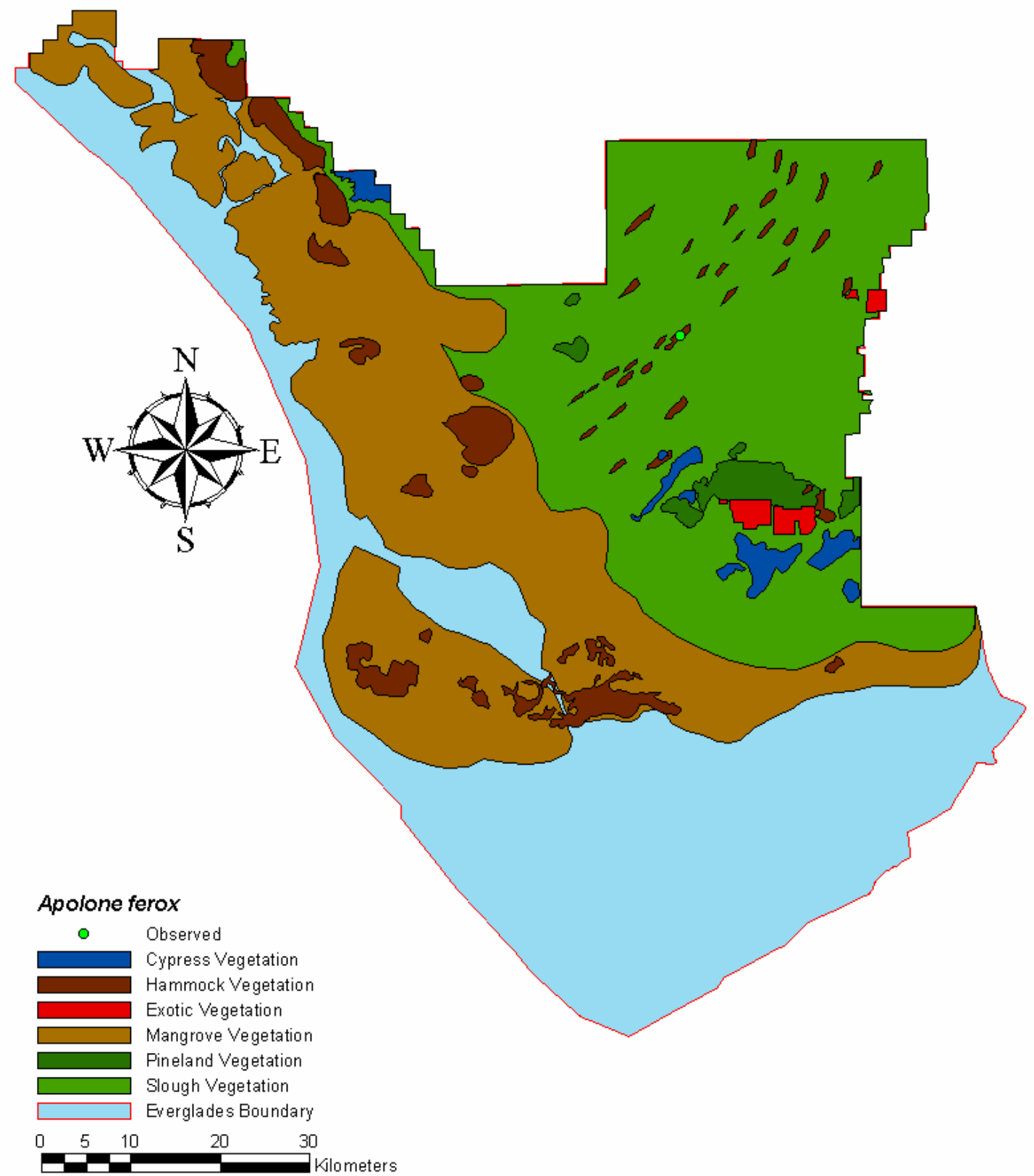

Figure 51: Apolone ferox locations

Map of all locations at which Apolone ferox were observed in Everglades National Park. 
Amphibians of Everglades National Park

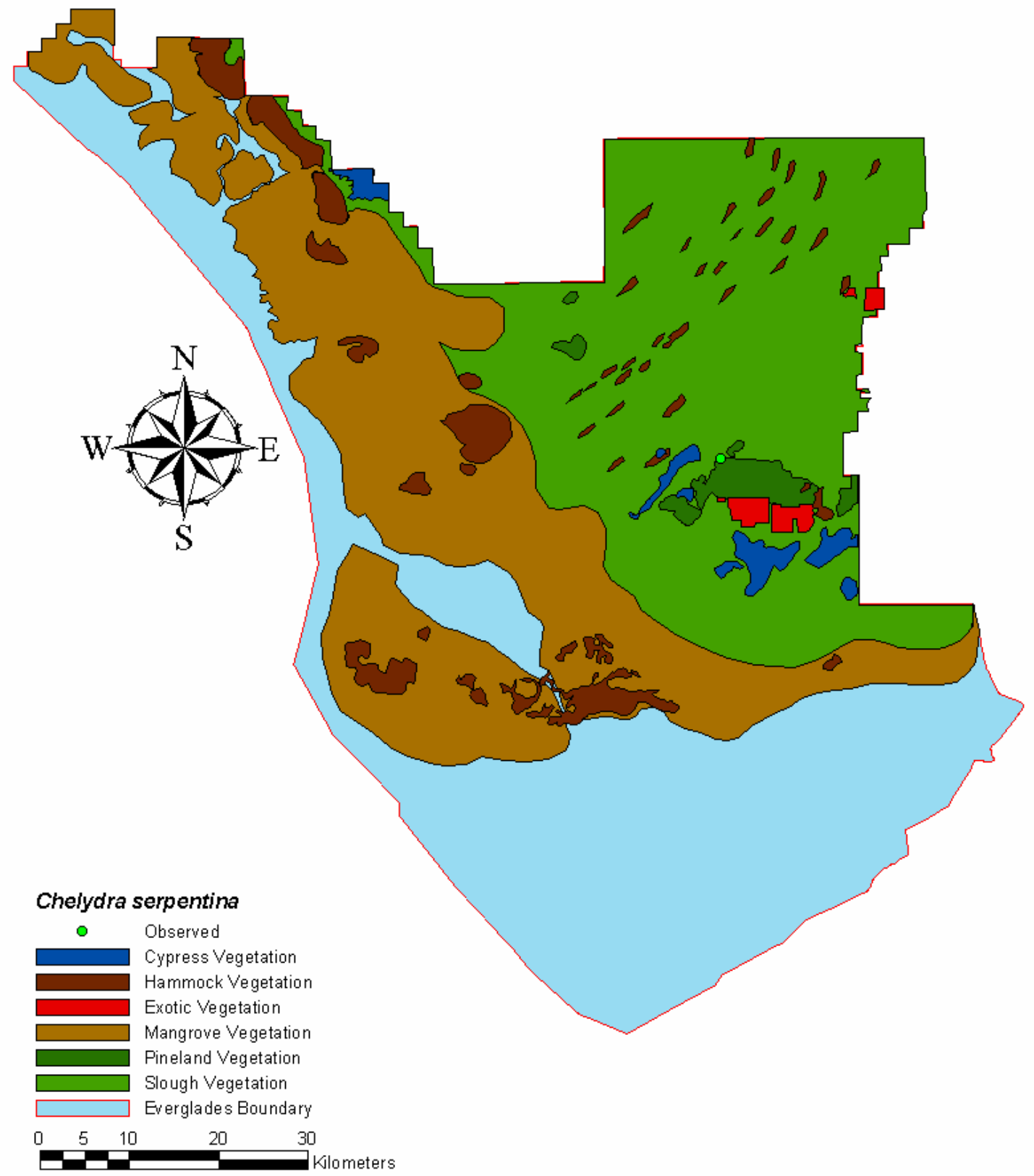

Figure 52: Chelydra serpentina locations

Map of all locations at which Chelydra serpentina were observed in Everglades National Park. 
Amphibians of Everglades National Park

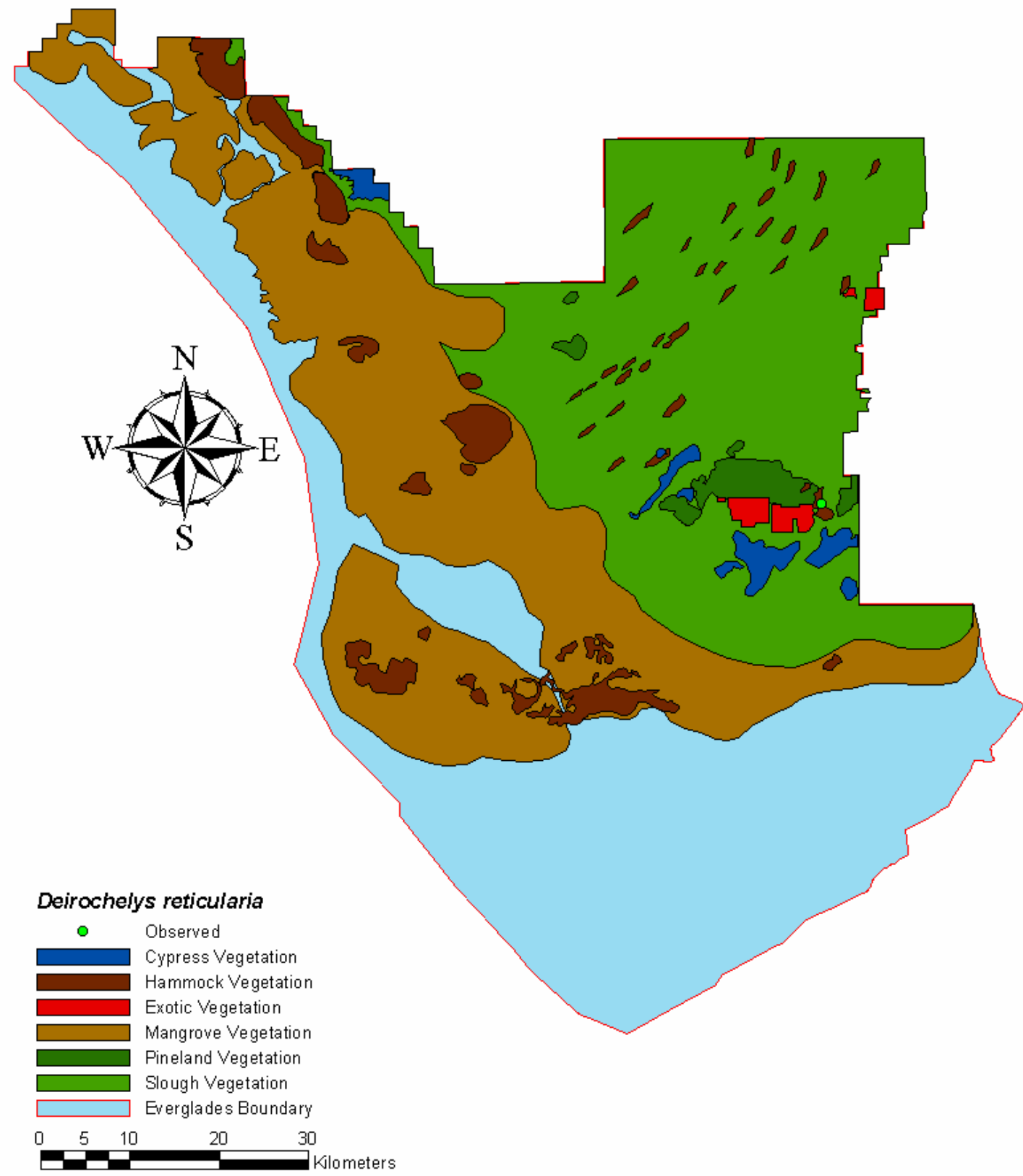

Figure 53: Deirochelys reticularia locations

Map of all locations at which Deirochelys reticularia were observed in Everglades National Park. 
Amphibians of Everglades National Park

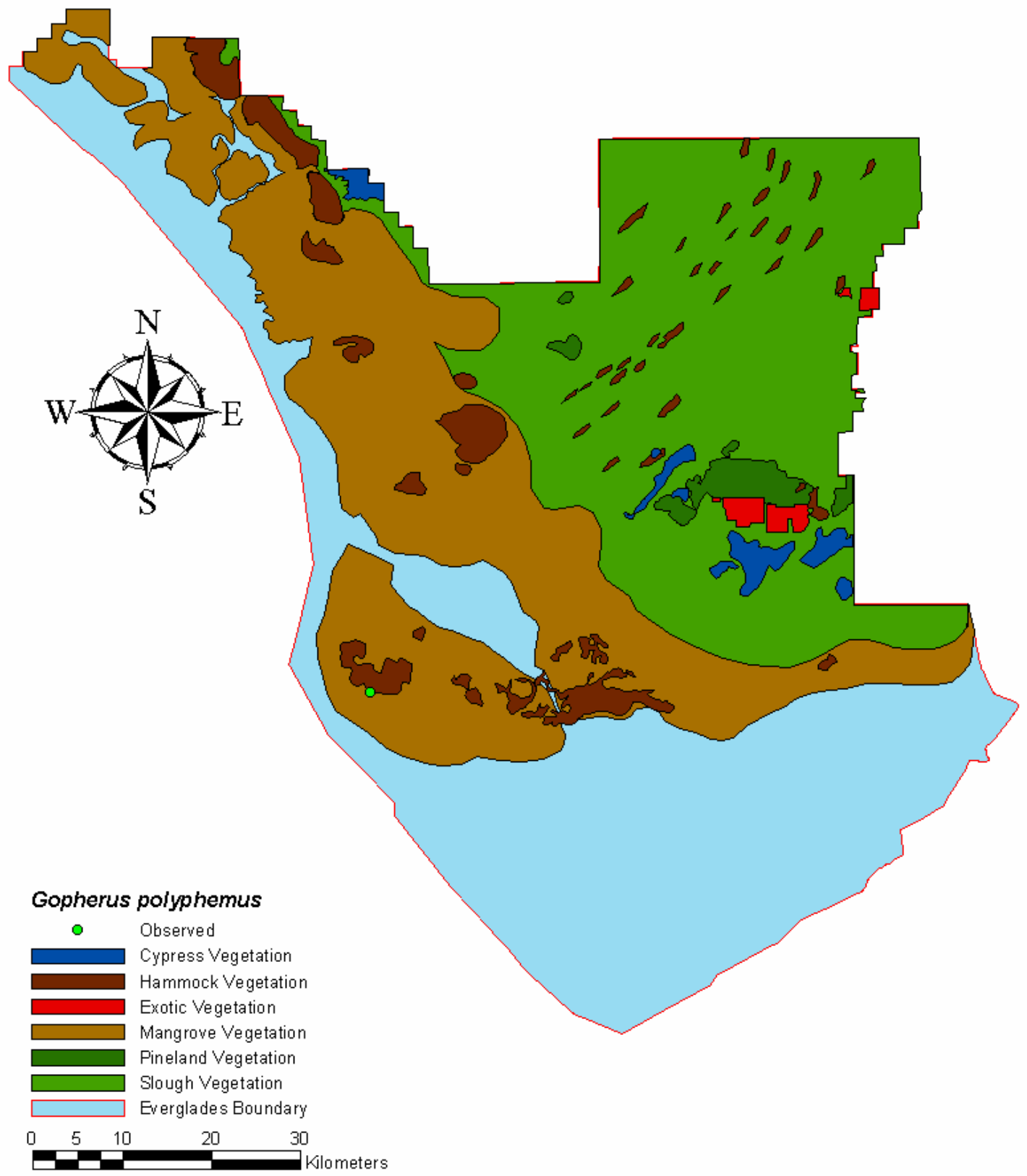

Figure 54: Gopherus polyphemus locations

Map of all locations at which Gopherus polyphemus were observed in Everglades National Park. 
Amphibians of Everglades National Park

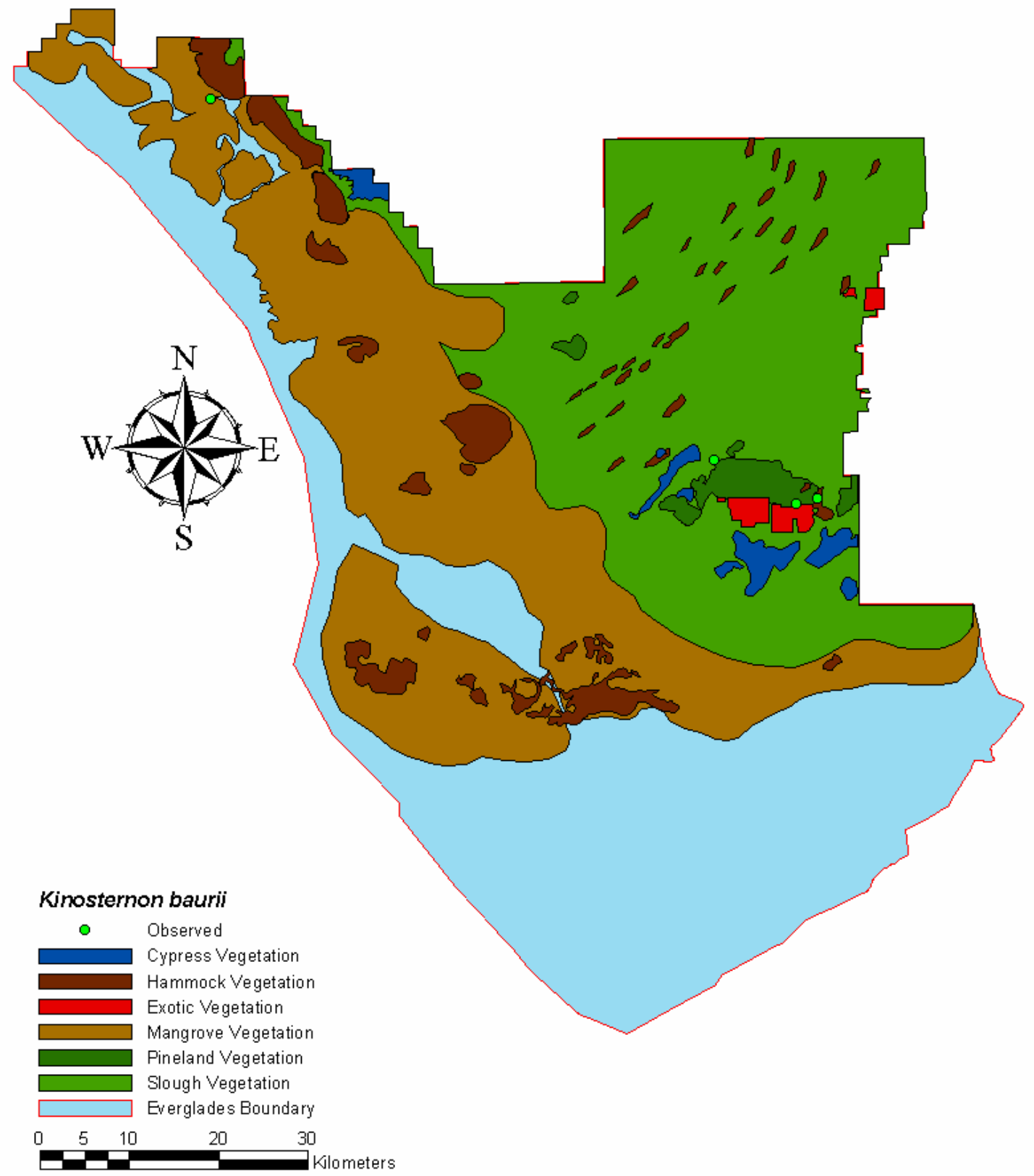

Figure 55: Kinosternon baurii locations

Map of all locations at which Kinosternon baurii were observed in Everglades National Park. 
Amphibians of Everglades National Park

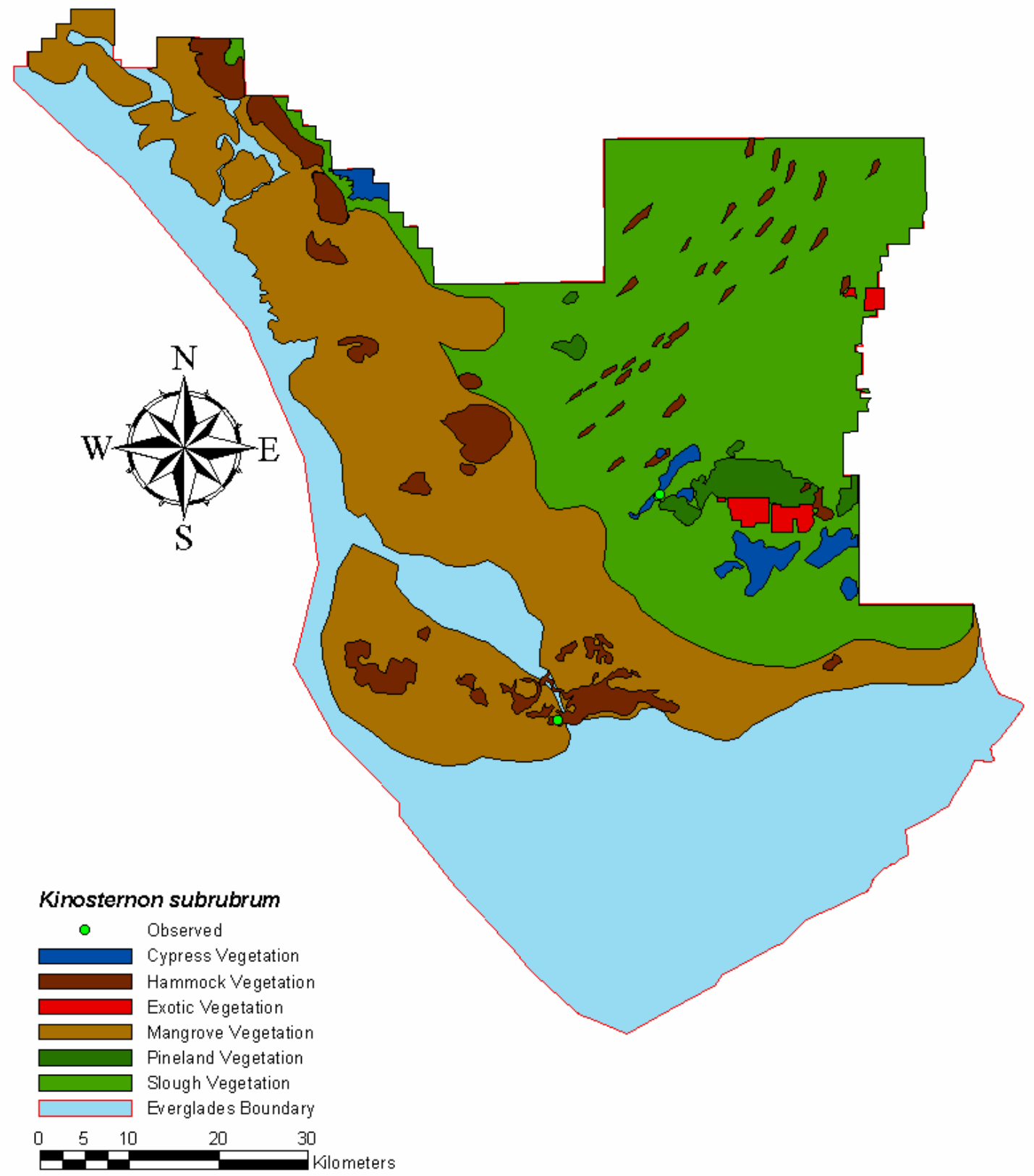

Figure 56: Kinosternon subrubrum locations

Map of all locations at which Kinosternon subrubrum were observed in Everglades National Park. 
Amphibians of Everglades National Park

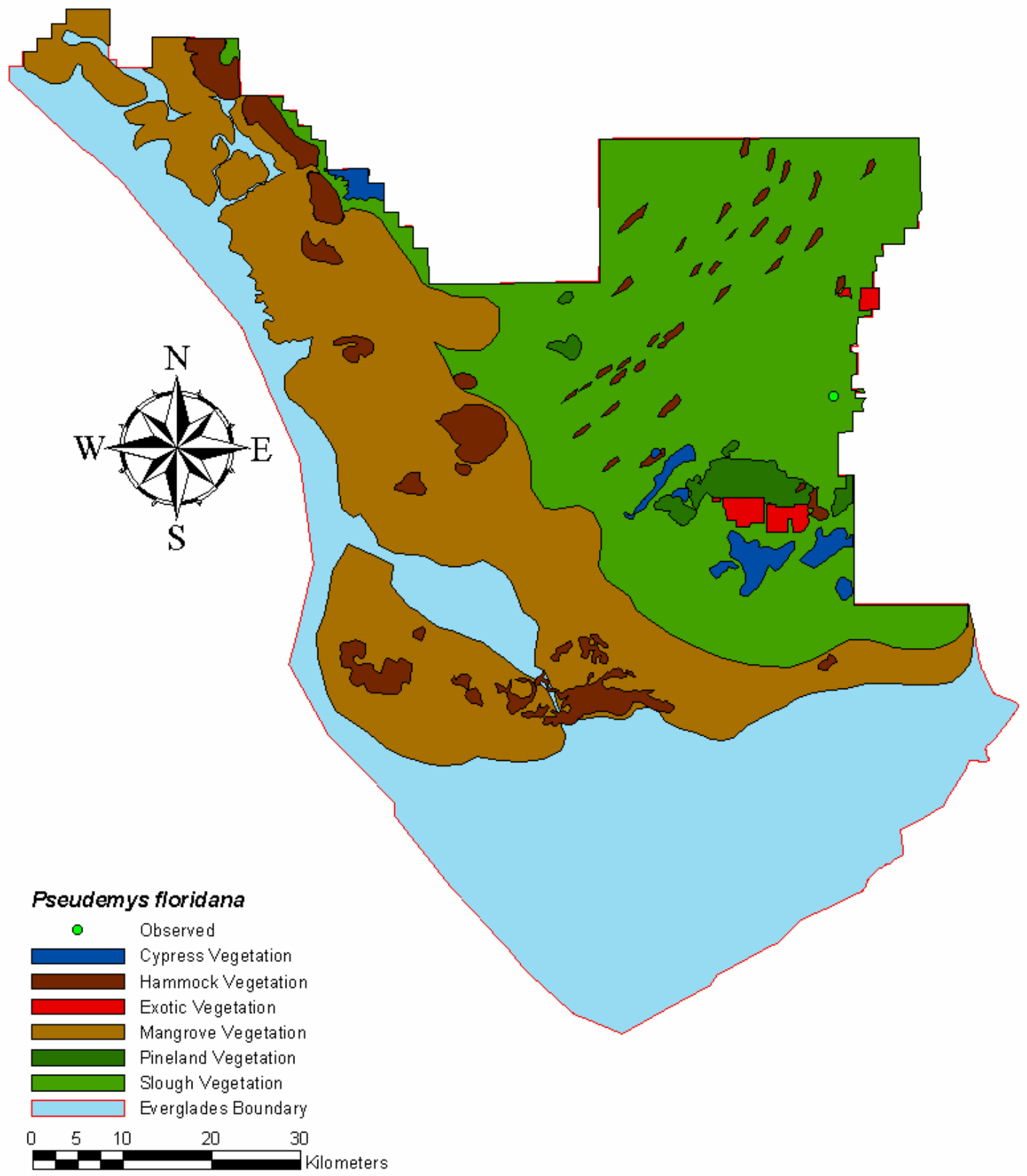

Figure 57: Pseudemys floridana locations

Map of all locations at which Pseudemys floridana were observed in Everglades National Park. 
Amphibians of Everglades National Park

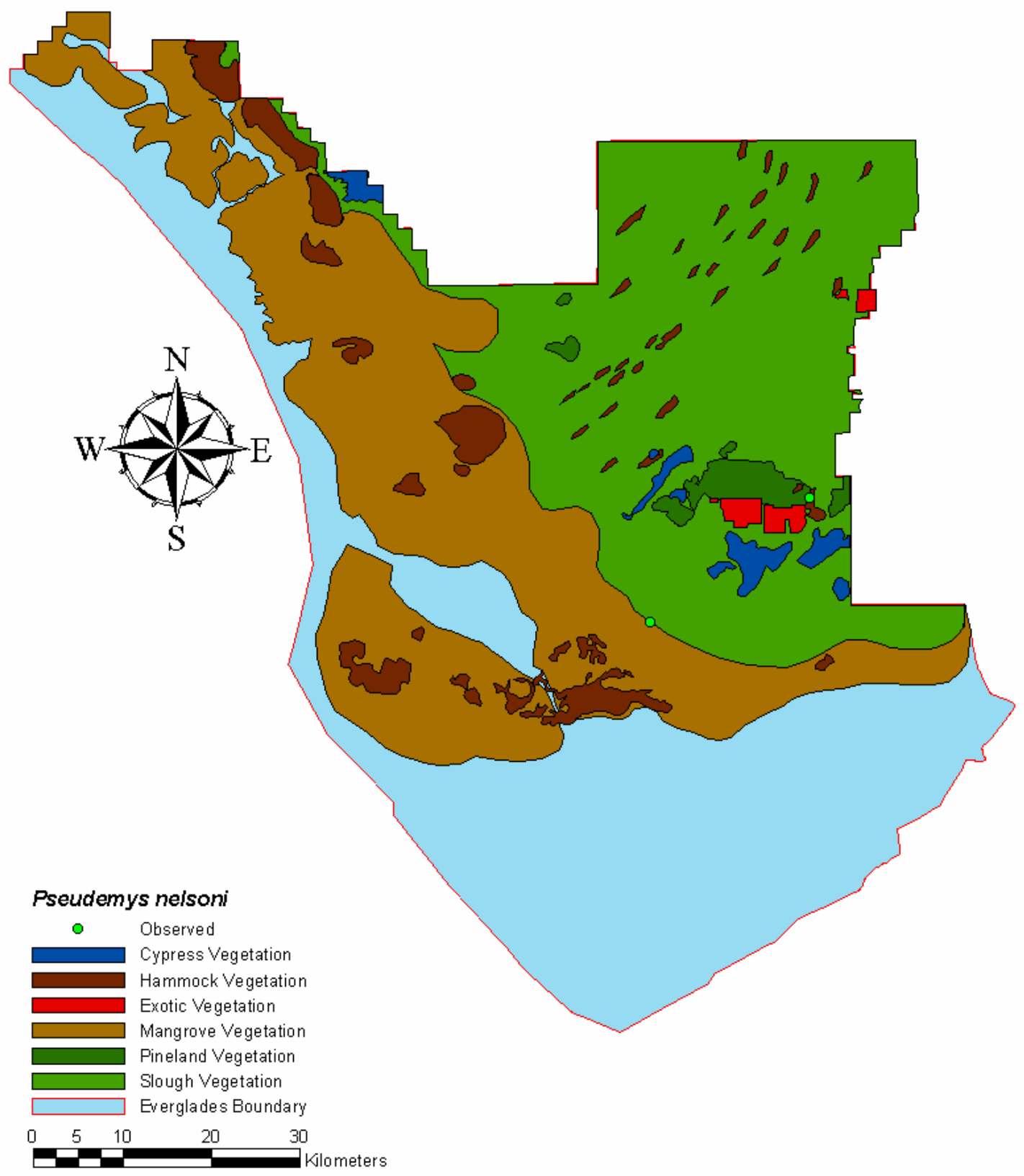

Figure 58: Pseudemys nelsoni locations

Map of all locations at which Pseudemys nelsoni were observed in Everglades National Park. 
Amphibians of Everglades National Park

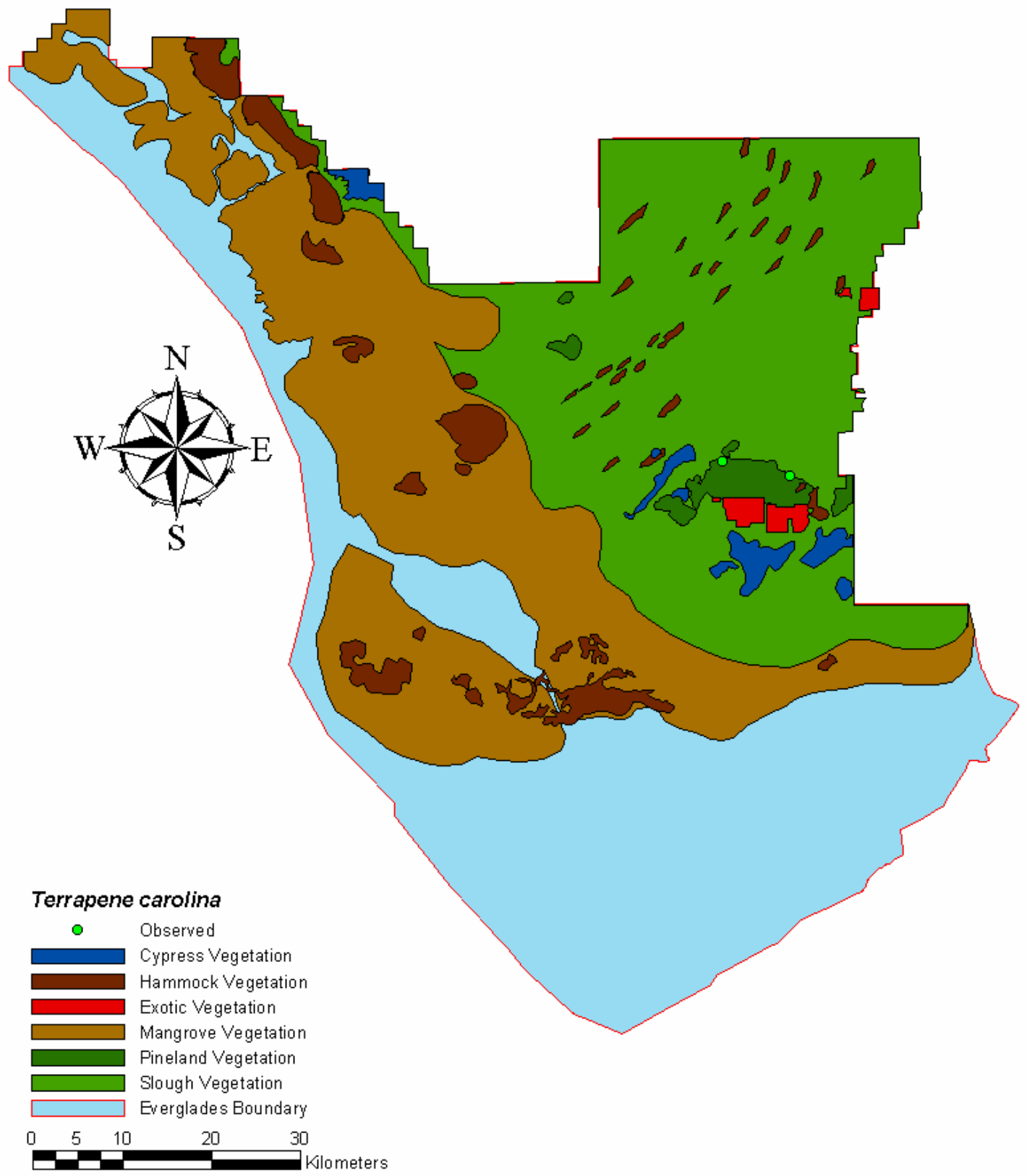

Figure 59: Terrapene carolina locations

Map of all locations at which Terrapene carolina were observed in Everglades National Park. 